\title{
Small mammal communities on a reclaimed mountaintop mine/ valley fill landscape in southern West Virginia
}

Howard Douglas Chamblin

West Virginia University

Follow this and additional works at: https://researchrepository.wvu.edu/etd

\section{Recommended Citation}

Chamblin, Howard Douglas, "Small mammal communities on a reclaimed mountaintop mine/valley fill landscape in southern West Virginia" (2002). Graduate Theses, Dissertations, and Problem Reports. 1460. https://researchrepository.wvu.edu/etd/1460

This Thesis is protected by copyright and/or related rights. It has been brought to you by the The Research Repository @ WVU with permission from the rights-holder(s). You are free to use this Thesis in any way that is permitted by the copyright and related rights legislation that applies to your use. For other uses you must obtain permission from the rights-holder(s) directly, unless additional rights are indicated by a Creative Commons license in the record and/ or on the work itself. This Thesis has been accepted for inclusion in WVU Graduate Theses, Dissertations, and Problem Reports collection by an authorized administrator of The Research Repository @ WVU. For more information, please contact researchrepository@mail.wvu.edu. 
Small Mammal Communities on a Reclaimed Mountaintop Mine/Valley Fill Landscape in Southern West Virginia

H. Douglas Chamblin

Thesis Submitted to the Davis College of Agriculture, Forestry and Consumer Sciences at West Virginia University

in partial fulfillment of the requirements for the degree of

Master of Science

in

Wildlife and Fisheries Resources

Division of Forestry

Petra Bohall Wood, Ph.D., Co-Chair

John. W. Edwards, Ph.D., Co-Chair

Roger J. Anderson, M.S.

Morgantown, West Virginia

2002

Keywords: Allegheny woodrat, fragmentation, mountaintop mining, Neotoma magister, Peromyscus, small mammals, West Virginia.

Copyright 2002

H. Douglas Chamblin 


\begin{abstract}
Small Mammal Communities on a Reclaimed Mountaintop Mine/Valley Fill Landscape in Southern West Virginia
\end{abstract}

\title{
H. Douglas Chamblin
}

Mountaintop mine/valley fill is a large-scale form of strip mining whose effects on small mammals had not previously been examined. Small mammals were captured by Sherman trap and drift fence array (pitfall and funnel traps) on 3 treatments representing the mined landscape (grasslands, shrub/pole areas, and fragmented forests) and intact forests representing the unmined condition. In addition, Allegheny woodrats (Neotoma magister) were targeted with Tomahawk live traps in 24 drainage channels constructed of large rocks. Peromyscus $(P$. leucopus and maniculatus) dominated Sherman captures (87\% of captures) and were the most common array capture (37\%). Eastern chipmunks (Tamias striatus), woodland jumping mice (Napaeozapius insignus), woodland voles, (Microtus pinetorum), and northern short-tailed shrews (Blarina brevicauda) were generally more abundant in forest treatments; Peromyscus spp., house mice (Mus musculus), southern bog lemmings (Synaptomys cooperi), and masked shrews (Sorex cinereus) were more abundant in reclaimed treatments. Meadow voles $(M$. pennsylvanicus), pygmy shrews ( $S$. hoyi), and smoky shrews (S. fumeus) were also captured, but abundances were similar among treatments. These species were generally found in expected habitats, although shrews were more common in reclaimed treatments than expected. Allegheny woodrats occupied 13 of 24 drainage channels, a habitat use not found in the literature. The percentage of rock ground cover and the density of tree stems $>15 \mathrm{~cm}$ diameter-at-breast-height were positively related to woodrat presence at channels. Boulders in channels form interstitial networks that may simulate rock outcrops, their typical habitat, but it is not known if the channels harbor self-sustaining populations. 


\section{ACKNOWLEDGMENTS}

I would like to thank my committee, Dr. Petra Bohall Wood and Dr. John W. Edwards, co-advisors, and Roger J. Anderson, WV Department of Natural Resources. Thank you, Dr. Wood, for always being available to generously lend insight and guidance (as well as invaluable edits on earlier versions of this thesis); Dr. Edwards, for your encouragement and expertise; and Roger Anderson, for providing a real-world perspective. I owe a debt of gratitude to Dr. Cathy Weakland for help at many steps in the completion of this project. For statistical consultation, I thank Dr. William Thane, Dr. Stanley Wearden, and George Seidel. For sharing GIS knowledge (and data layers), I thank Melissa Balcerzak. In addition, I heartily thank the people who helped collect data for this project: Jessica Kapp, Rob Dempsey, Todd McCoy, Robin Pumphrey, Josh Carlson, Jennifer Mravintz Williams, Jon Simmons, Tim Dellinger, C. Weakland, M. Balcerzak, and Amanda Carroll. For funding this project, I thank the Coal and Energy Research Bureau, the West Virginia State Legislature, and the U.S. Environmental Protection Agency. Arch Coal and Cannelton mining companies and the Amherst Corporation made this research possible by allowing access to their properties, while Ark Land Company provided field housing. I would also like to thank Becky Nestor at the WV Cooperative Fish and Wildlife Research Unit for administrative support provided with a rare sense of cheer and good humor.

Finally, I dedicate this thesis to my family and friends and to the memory of my grandfather, J. Howard Chamblin (1907-2001). I am grateful to my parents, Larry and Gill, for a lifetime of love and encouragement; to my siblings, Matt, Kevin, and Emily, and my grandmothers, Mary Anderson and Betty Chamblin, for their support and love. To Kelly and the many great friends that I've made at WVU, I give a warm thank you for making this an enjoyable and fulfilling experience. 


\section{TABLE OF CONTENTS}

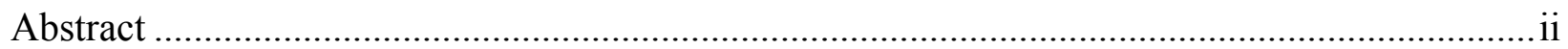

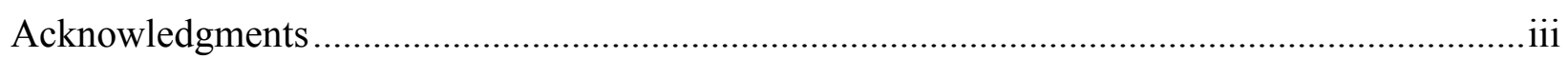

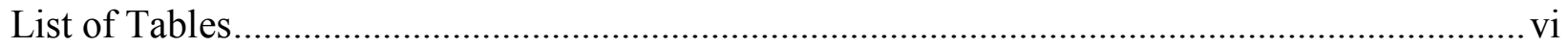

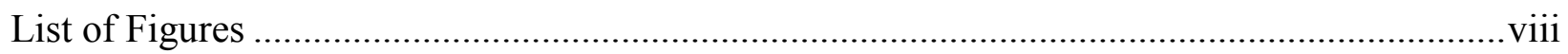

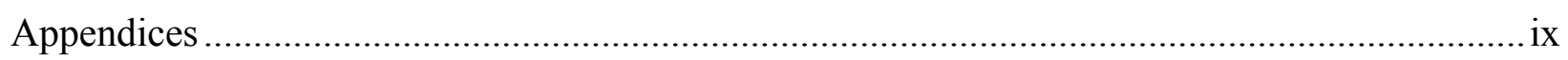

Chapter 1 - Introduction and Literature Review .......................................................... 1

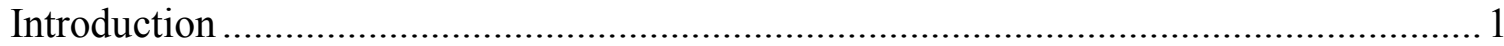

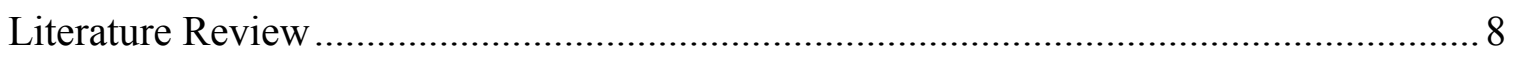

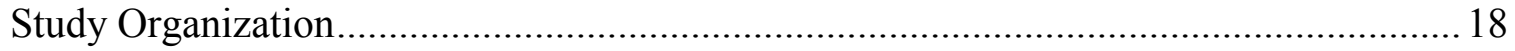

Chapter 2 - Small Mammal Richness and Abundance on a Reclaimed Mountaintop Mine

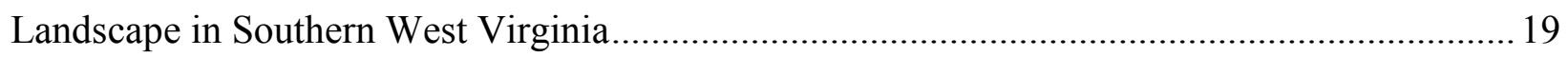

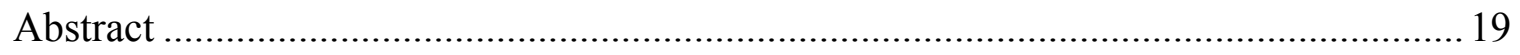

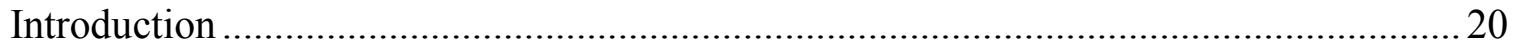

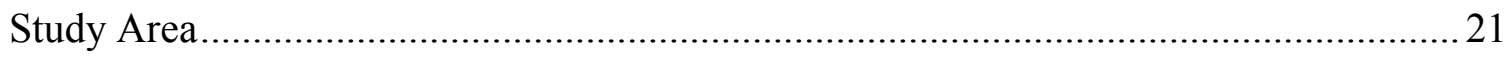

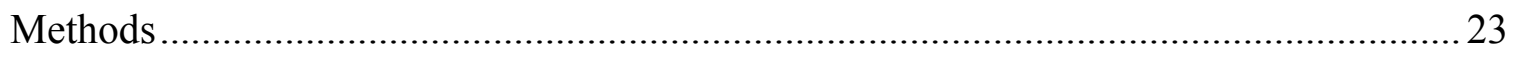

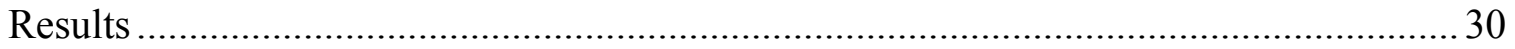

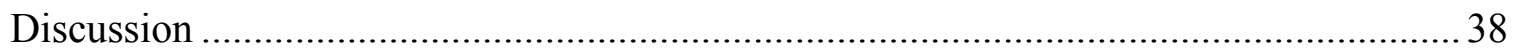

Chapter 3 - Use of Drainage Channels by Allegheny Woodrats on a Reclaimed Mountaintop

Mine Landscape in Southern West Virginia ................................................................... 71

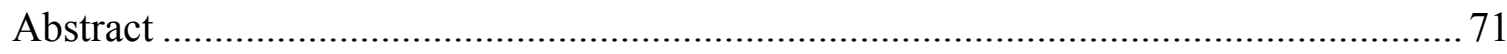

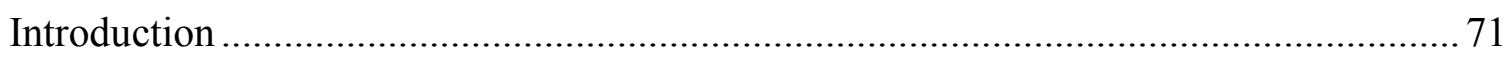

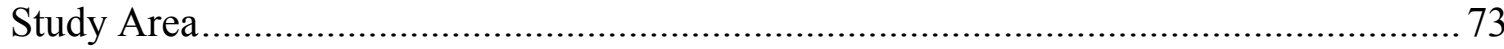

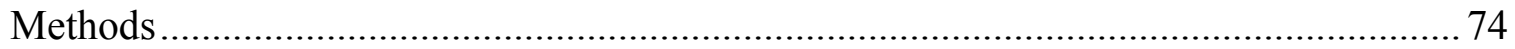

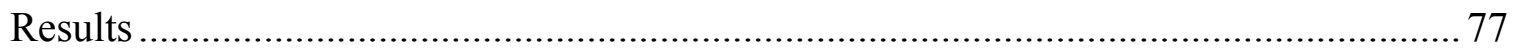

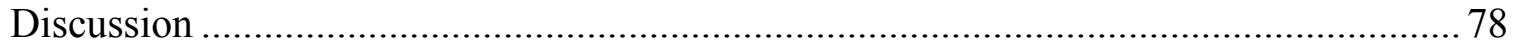

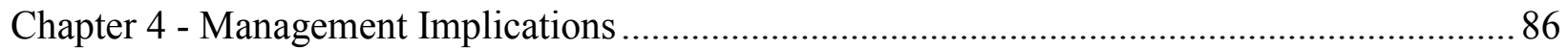

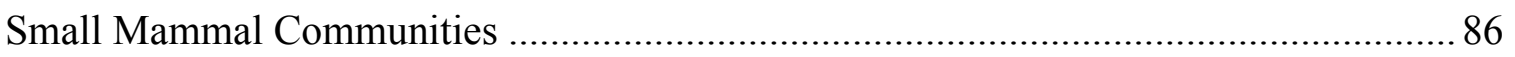

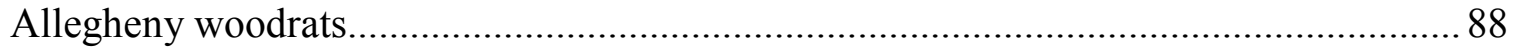

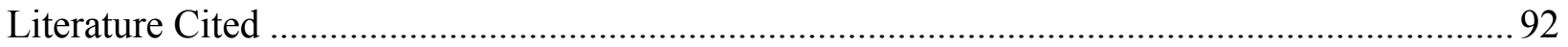


Appendix A - Statistical Models used in Analysis of Variance of Small Mammal Richness, Abundance and Habitat Variables ............................................................................................. 108

Appendix B - Maps and Aerial Photographs of Study Sites .................................................... 110 


\section{LIST OF TABLES}

\section{Chapter 2.}

Table 1. Average mammalian species richness (\# species/transect), relative abundance (mammals/100 trap nights), and standard errors (SE) in grassland, shrub/pole, fragmented forest, and intact forest treatments on MTMVF landscapes in southern West Virginia for 1999 and 2000.

Table 2. Average richness (\# species/transect) and abundance (mammals/100 trap nights) compared between 1999 and 2000 in grassland, shrub/pole, fragmented forest, and intact forest treatments on MTMVF landscapes in southern West Virginia based on Sherman trapping.

Table 3. Similarity indices comparing small mammal community composition among grassland, shrub/pole, fragmented forest, and intact forest treatments on MTMVF landscapes in southern West Virginia based on Sherman trapping and drift fence array trapping

Table 4. Relative abundance (mammals/100 trap nights), and standard error (SE) of Peromyscus spp. age and sex groups, and adult/juvenile ratios in grassland, shrub/pole, fragmented forest, and intact forest treatments based on Sherman trapping on MTMVF landscapes in southern West Virginia for 1999 and 2000.

Table 5. Percentage of Peromyscus spp. adults in reproductive condition in grassland, shrub/pole, fragmented forest, and intact forest treatments based on Sherman trapping on reclaimed MTMVF landscapes in southern West Virginia in 1999 and 2000.

Table 6. Mean and standard error (SE) of habitat variables measured at Sherman trapping sites in grassland $(\mathrm{N}=10)$, shrub/pole $(\mathrm{N}=6)$, fragmented forest $(\mathrm{N}=10)$, and intact forest $(\mathrm{N}=10)$ treatments on MTMVF landscapes in southern West Virginia in 1999.

Table 7. Mean and standard error (SE) of habitat variables measured at drift fence array trapping sites in grassland $(\mathrm{N}=3)$, shrub/pole $(\mathrm{N}=3)$, fragmented forest $(\mathrm{N}=3)$, and intact forest $(\mathrm{N}=3)$ treatments on MTMVF landscapes in southern West Virginia in 2000.

Table 8. Significant variables from multiple linear regressions of mammal species richness, total abundance, and Peromyscus spp. abundance on habitat and environmental variables in grassland, shrub/pole, fragmented forest, intact forest treatments on MTMVF landscapes in southern West Virginia.

Table 9. Significant variables from logistic regression of species presence/absence data on habitat and environmental variables on MTMVF landscapes in grassland, shrub/pole, fragmented forest, intact forest treatments on MTMVF landscapes in southern West Virginia.

Table 10. Species captured and method of capture from 1999-2001 in grassland, shrub/pole, fragmented forest, and intact forest treatments on MTMVF landscapes in southern West Virginia. 


\section{Chapter 3.}

Table 1. Shrub and tree species found at 24 reclaimed drainage channels trapped for Allegheny woodrats on MTMVF landscape in southern West Virginia and their potential food value to woodrats.

Table 2. $T$-test comparison of means of habitat variables at 13 rock drainage channel sites where woodrats were present and 11 where they were absent on MTMVF landscapes in southern West Virginia.

Table 3. Classification of reclaimed drainage channels on MTMVF landscape in southern West Virginia, using codes developed by the Pennsylvania Game Commission (1996) for

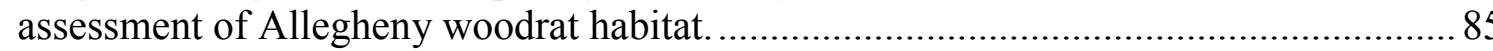

\section{Chapter 4.}

Table 1. Mammal species expected to occur in southern West Virginia and ability of study methods to detect their presence. 


\section{LIST OF FIGURES}

\section{Chapter 2.}

Figure 1. Species richness (\# species per transect), total small mammal abundance $(\# / 100$ trap nights), and Peromyscus abundance (\#/100 trap nights) plotted against years since reclamation at each reclaimed site (grassland or shrub/pole treatment) where Sherman trapping took place on MTMVF landscapes in southern West Virginia. Abundance values from 2 trapping sessions are plotted separately.

Figure 2. Species richness (\# species per transect), total small mammal abundance (\#/100 trap nights), and Peromyscus abundance (\#/100 trap nights) plotted against years since reclamation at each reclaimed site (grassland or shrub/pole treatment) where drift fence array trapping took place on MTMVF landscapes in southern West Virginia. Abundance values from 13 trapping sessions are plotted separately.

Figure 3. Average weekly temperatures recorded in Charleston, West Virginia in 1999, 2000, and 2001 as compared to 30-year normals (NOAA/NWS).

Figure 4. Weekly precipitation reported in Charleston, West Virginia in 1999, 2000, and 2001 as compared to 30-year normals (NOAA/NWS).

\section{Chapter 4.}

Figure 1. Total small mammal abundance and Peromyscus abundance (\# individuals/100 trap nights) versus percent bare ground for Sherman trapping data. 


\section{APPENDICES}

Appendix A. Statistical Models used in Analysis of Variance of Small Mammal Richness, Abundance and Habitat Variables

Table A. 1. Analysis of variance model used to test the effects of treatment on species richness, total small mammal abundance, species-specific abundance, and reproductive condition of Peromyscus spp. individuals for 1999 Sherman live-trapping data.

Table A. 2. Analysis of variance model used to test the effects of treatment on species richness, total small mammal abundance, species-specific abundance, and reproductive condition of Peromyscus spp. individuals for 2000 Sherman live-trapping data.

Table A. 3. Analysis of variance model used to test the effects of year on species richness, total small mammal abundance, species-specific abundance, and reproductive condition of Peromyscus spp. individuals (each treatment analyzed separately) for Sherman livetrapping data.

Table A. 4. Analysis of variance model used to test the effects of treatment on species richness, total small mammal abundance, and species-specific abundance for drift fence array data.

Table A. 5. Analysis of variance model used to test the effects of treatment on habitat variables for Sherman and drift fence array data.

Appendix B. Maps and Aerial Photographs of Study Sites.

Figure B. 1. Location of study sites at Hobet 21, Daltex, and Cannelton Mines in southern West Virginia.

Figure B. 2. Aerial photograph of Hobet 21 Mine in Boone County, West Virginia showing locations of Sherman trapping transects, woodrat trapping sites, and drift fence arrays. Inset shows Hill Fork area located about $8 \mathrm{~km}$ northeast of main complex.

Figure B. 3. Aerial photograph of Daltex Mine in Logan County, West Virginia showing locations of Sherman trapping transects and drift fence arrays.

Figure B. 4. Aerial photograph of Cannelton Mine on the border of Fayette and Kanawha Counties, West Virginia showing locations of Sherman trapping transects and drift fence arrays. Inset shows Ash Fork intact forest site located about $14 \mathrm{~km}$ northeast of the mine. 


\title{
CHAPTER 1 - INTRODUCTION AND LITERATURE REVIEW
}

\section{INTRODUCTION}

\section{Research Justification and Objectives}

\author{
Small Mammals
}

Small mammals are an important component of biological diversity, and their populations are affected by forest fragmentation (Gottfried 1977, Yahner 1986, Yahner 1992, Nupp and Swihart 1996, Rosenblatt et al. 1999). Further, small mammals are the primary prey base for a variety of mammalian and avian predators. They make up a significant percentage of the diet of many animals, including hawks (Acciptrinae), owls (Strigidae and Tytonidae), red fox (Vulpes vulpes), gray fox (Urocyon cinereoargenteus), coyote (Canis latrans), and weasels (Mustela spp.) (Mindell 1978, Yearsley and Samuel 1980, McGowan and Bookout 1986); thus changes in their abundance can affect other species. Additionally, small mammals are ecologically important as predators, herbivores, and detritivores, seed dispersers for many plant species (Mumford and Bramble 1973, Bayne and Hobson 1998).

The environmental impact of mountaintop mine/valley fill operations (MTMVF) was studied in the mid-1970s when the Environmental Protection Agency (EPA) and the Skelly and Loy environmental consulting firm examined reclaimed mines in Kentucky and West Virginia (Robins and Hutchins 1979, 1984). Their assessment of the impacts of mountaintop removal mining included studies on water quality, soils, and stream macroinvertebrate communities, but did not examine the effects of mountaintop removal mining on terrestrial wildlife species. Allaire (1979) studied avifauna on MTMVF sites in Kentucky and compiled a literature review of other bird studies on MTMVF sites for the Institute for Mining and Minerals Research (Allaire 1980). 
Few bird studies have been conducted and studies on other taxa on the MTMVF landscape are absent from the literature.

Although we found no previous studies of small mammal populations on MTMVF areas, there have been several studies of small mammals on strip-mined lands throughout the coal mining regions of the mid-western and eastern United States (Verts 1957, De Capita and Bookout 1975, Sly 1976, Hansen and Warnock 1978, Urbanek and Klimstra 1986, McGowan and Bookout 1986). Several of these studies found that small mammal communities on mines differ as a function of time since mining activity ceased (Verts 1957, Wetzel 1958, Sly 1976, Hansen and Warnock 1978, McGowan and Bookout 1986). Five studies compared small mammal populations on reclaimed lands with those on unmined areas (Wetzel 1958, De Capita and Bookout 1975, Kirkland 1976, Voight and Glenn-Lewin 1979, Urbanek and Klimstra 1986). However, results from these studies differed. Wetzel (1958) and Kirkland (1976) found abundance to be greater on unmined lands, while the other 3 studies found abundance to be greater on previously mined lands. Species richness trends also were inconsistent as more species were found on unmined land in 3 studies (De Capita and Bookhout 1975, Kirkland 1976, Voight and Glenn-Lewin 1979) and on mined land in 1 study (Wetzel 1958); the $5^{\text {th }}$ study (Urbanek and Klimstra 1986) did not find a difference in richness. Further, unmined lands in 2 studies (De Capita and Bookout 1975, Voight and Glenn-Lewin 1979) included habitats other than intact forests that could have confounded the results. Consequently, additional research is needed to clarify the effects of MTMVF on small mammal populations.

\section{Allegheny Woodrats}

The Allegheny woodrat (Neotoma magister) is a species typically found in rock outcrops and other rock structure (Poole 1940) in forested areas in the Appalachian Mountains. It is listed 
as threatened, endangered, or as a species of concern throughout its range, and is thought to be affected by habitat fragmentation (Balcom and Yahner 1996, Castleberry et al. 2001). Woodrat populations appear to be stable in West Virginia, the center of the species' geographic range, although its official status is unknown (Mengak 1996, Stihler and Wallace 1996, Wood 2001). For these reasons, it is important to document Allegheny woodrats' use of manmade drainage channels on a landscape fragmented by MTMVF operations in West Virginia.

\section{Objectives}

My study was undertaken as part of a broad effort to document the effects of MTMVF on wildlife, contributing to a comprehensive environmental impact statement (EIS) as mandated by the federal government under the National Environmental Policy Act (NEPA). Specifically, my contribution to the EIS had the following objectives:

1. quantify and compare small mammal abundance and species richness among 4 treatments; three treatments represented the post-mining landscape: grasslands (recently reclaimed sites), shrub/pole stands (older reclaimed sites), and fragmented forests surrounded on 3 sides by reclaimed mine lands; the $4^{\text {th }}$ treatment, mature intact forests, represented the pre-mining landscape;

2. identify habitat and environmental variables related to small mammal abundance and species richness in the 4 treatments; and

3. assess Allegheny woodrat use of reclaimed rock drainage channels and identify habitat characteristics related to woodrat presence. 


\section{Coal Mining in West Virginia}

\section{Background}

Coal mining in West Virginia dates back to the early 1700s (OSM 2001), when smallscale underground and surface operations extracted reserves using picks, shovels, and mules. In the early to mid-1800s, however, coal mining became a big business when the industrial revolution created an increase in demand for coal. Room and pillar underground mines were typical, and by 1890, electric-powered machinery came into use for cutting, loading, and hauling. Technology proceeded quickly from there, with advancements in mining technology bringing about large-scale surface mining by about 1916. Surface mining in the steep-sloped Appalachian Mountains was originally accomplished by the use of contour mines that followed along slopes, cutting into hillsides to reach coal seams (Hutchins 1978). Once a seam is exposed, augers drill out the coal. With current technology, augers can access an entire coal seam by boring in about $300 \mathrm{~m}$ from each side of a ridgeline. About $40 \%$ of the coal, however, must be left in place to preserve the structural integrity of the mountaintop (Nieman and Merkin 1995). The 1977 Surface Mining Control and Reclamation Act (SMCRA) requires that rock and soil overburden (spoil) removed in the process be used to re-grade slopes into the "approximate original contour" (AOC) (OSM 1999). Prior to this legislation, spoil was dropped downslope from the mining operation, leaving behind a vertical highwall on the uphill side of the mine and a flat bench on the downhill side. Approximately 32,000 km of highwall remain in West Virginia as a legacy of contour mining prior to SMCRA (Hutchins 1978).

\section{Mountaintop Removal Mine/Valley Fill}

In recent years, the MTMVF method of surface mining has become prevalent, especially in southern West Virginia. MTMVF differs from contour mines in that it occurs on a much larger 
scale, with resulting reclaimed land areas of $25 \mathrm{~km}^{2}$ or more. Though it makes up only $17 \%$ of surface mine permits, MTMVF accounts for $44 \%$ of the surface-mined area (OSM 2001). The method was first used in the state in 1967 on the Cannelton Mine about $50 \mathrm{~km}$ southeast of Charleston. It was seen as an improvement on contour mining because it increased the efficiency of removing coal and made reclamation an easier task (Robins and Hutchins 1984, Greene and Raney 1979). Instead of boring into coal seams from the side of the mountain, rock and soil overburden is removed from an entire ridgetop, allowing all of the coal to be mined from upper seams in the Kanawha and Allegheny formations (Nieman and Merkin 1995, Fedorko and Blake 1998). Since much of the best quality, low-sulfur coal is found in these thin seams toward the top of the mountains, this method proved to be the most efficient and thorough (Nieman and Merkin 1995, Fedorko and Blake 1998). Reclamation of MTMVF sites is accomplished by placing most of the spoil into adjacent valleys in what are called valley fills or head-of-hollow fills. Fills are later graded into terraces to increase the stability of the slope and fitted with a rock drainage channel to minimize soil runoff (Greene and Raney 1979, Robins and Hutchins 1984). The remaining spoil is placed back onto the flattened ridgeline. In some cases, AOC is restored, but generally MTMVF permits are granted with an AOC variance, allowing the formation of a plateau or gently rolling topography with no highwalls. Variances are granted under section 515(c) of SMCRA for approved postmining land uses, including industrial, commercial, agricultural, residential, or public use (OSM 1999).

Surface mining production increased slowly in the 1920s and 1930s, but World War II created a period of more rapid growth followed by a period of little change (Hutchins 1978). In the past 20 years, production has again increased in West Virginia, going from 19\% to $32 \%$ of the state's coal intake (OSM 2001). This rise is attributable to an increase in the use of MTMVF 
in southern West Virginia coal fields (Fedorko and Blake 1998, OSM 2001). Two factors have led to the prevalence of MTMVF in this region. First, improvements in technology have made it possible to economically remove the large volume of overburden that is necessary to access coal seams. MTMVF operations are highly mechanized, with miles of conveyors and vast earthmoving machines, such as walking draglines, electric shovels, and 220,000-kg-capacity dump trucks. These machines operate 24 hours a day, 363 days a year, and require a relatively small labor force; for instance, a typical dragline, which weighs 3.6 million $\mathrm{kg}$, stands 20 stories tall, and wields a $62 \mathrm{~m}^{3}$ bucket, requires only 2 operators (personal communication John McDaniel, Arch Coal 2001). The second reason that MTMVF operations have become so numerous in southern West Virginia is the increase in demand for low-sulfur coal, such as that found in the Allegheny and Kanawha formations (Fedorko and Blake 1998). This type of coal has a high BTU rating, and it is compliant with the 1990 Clean Air Act because it burns cleaner, releasing less acid-rain-causing sulfur-dioxide into the air (EPA 1998).

Since about 1995, the practice of MTMVF has been the subject of national controversy and debate. Articles have appeared in numerous publications, including Audubon (Williams 2001), The Charleston Gazette (Ward, Jr. 1998, 2001, 2002), The New York Times (Janofsky 1998), The New York Times Magazine (Goodell 2001), The Washington Post (Warrick 1998), U.S. News and World Report (Loeb 1997), and Utne Reader (Vollers 1999); national news programs such as ABC's Nightline (1998) and CBS' 60 Minutes (1998) have also covered the issue. Critics claim that MTMVF operations are in violation of Section 404 of the Clean Water Act (CWA) for the placing of dredge and fill into streams, as well as SMCRA for failing to either restore AOC or provide an acceptable postmining land use (Vollers 1999, Williams 2001). On these grounds, in April 1998, the West Virginia Highlands Conservancy (WVHC) and 10 
local citizens brought a lawsuit against the West Virginia Division of Environmental Protection (DEP) and the Army Corps of Engineers (COE) in an attempt to cease MTMVF permitting (Gardner and McLusky 2000). In December 1998, the plaintiffs agreed to a settlement on all claims against the COE. In exchange, the federal government agreed that it would invoke NEPA and produce an EIS evaluating the effects of MTMVF on terrestrial and aquatic habitat. A comprehensive 2-year study would be undertaken, involving the Environmental Protection Agency (EPA), the U.S. Fish and Wildlife Service, the COE, the Office of Surface Mining and Reclamation Enforcement (OSM), and the DEP. Furthermore, the COE agreed to implement a policy requiring individual CWA Section 404 permits for proposed valley fills of more than 250 acres rather than granting them under its more lenient nationwide permit program (Gardner and McLusky 2000).

Prior to the lawsuit, Arch Coal had applied for a permit to expand its Spruce Fork operation (Daltex Mine) in Logan County. The DEP was prepared to issue the permit, but decided to delay while awaiting the outcome of the suit. After settlement, the federal defendants argued that the Spruce Fork permit should be exempted from the more stringent CWA Section 404 permitting requirements. The plaintiffs did not agree, and the matter was brought to U.S. District Court in Charleston where, in October 1999, Chief Judge Charles Haden issued a preliminary injunction against permitting of MTMVF operations (Gardner and McLusky 2000). In the decision, he wrote of the "imminent and irreversible harm" that would be done to the streams as well as to the family living at the bottom of the hollow where mining was proposed (Vollers 1999). Although he later granted a stay against Arch Coal allowing active MTMVF operations to continue, the fate of the MTMVF practice and the Spruce Fork permit were put on hold pending the outcome of the company's appeal. In April 2001, judges at the $4^{\text {th }}$ U.S. Circuit 
Court of Appeals overturned Haden's decision (Ward 2001), ruling that Haden had no jurisdiction because it was a state matter. They ordered Haden to dismiss the case so that it could be filed in state court. The WVHC vowed to appeal the matter to the U.S. Supreme Court, but, in January 2002, the Supreme Court declined to hear the case, allowing the appeals court ruling to stand (Ward 2002). This puts regulation of MTMVF operations in West Virginia in the hands of the DEP, pending further lawsuits in state court. The permit for Arch Coal's Spruce Fork expansion has not been ruled upon at the time of this writing.

\section{LITERATURE REVIEW}

\section{Strip-mining and Small Mammals}

Although no previous study has examined small mammal populations on MTMVF areas, there have been several studies of small mammals on strip-mined lands throughout the coal mining regions of the mid-western and eastern United States (Verts 1957, De Capita and Bookout 1975, Sly 1976, Hansen and Warnock 1978, Urbanek and Klimstra 1986, McGowan and Bookout 1986). Another study assessed small mammal populations in the Adirondack Mountains of New York on reclaimed open-pit mines for ilmenite (titanium) and magnetite (iron) ores (Kirkland 1976). The mining techniques used in these studies were considerably different from mountaintop removal mining, and the studies did not take place in West Virginia. However, they provide information on small mammal populations following a severe disturbance and subsequent reclamation.

\section{Small Mammal Succession on Reclaimed Mines}

Several studies found that small mammal communities on mines differ as a function of time after the mining activity ceased (Verts 1957, Wetzel 1958, Sly 1976, Hansen and Warnock 1978, McGowan and Bookout 1986). Verts (1957) studied small mammals on 18 strip-mined 
sites in Illinois 4-22 years after reclamation. The mining process in the relatively flat state of Illinois is somewhat different from that used in the more topographically complex landscape of West Virginia. Verts (1957) describes the process of stripping the soil and rock overburden and then piling it behind the active mine. As the mining operation progresses, a series of parallel ridges are left behind, each about 6.1 to 9.1-m high and about 15.2-m apart. Verts (1957) focused on white-footed mice (Peromyscus leucopus) and prairie deer mice (P. maniculatus bairdii) and did not report other species captured. He found that the more recently mined areas, where the prairie deer mouse was the dominant species, had the highest overall abundance. The earliest-mined sites, where only the white-footed mouse was captured, had the next highest abundance. Lowest abundance was found on intermediate-aged sites where both species occurred in approximately equal numbers. His analysis of vegetative characteristics did not show differences in species composition, relative abundance, height of vegetation, or percentage of bare ground among the different-aged strip mines. More recently mined sites did have smaller tree diameters and tree height than the earlier mined sites. Still, the data did not support the idea that differences in Peromyscus species occupation of these sites was due to plant succession. Instead, Verts (1957) speculated that it was caused by differences in light, water, food, accumulated litter, temperature, and relative humidity among the various-aged strip mines.

Sly (1976) conducted a similar study in Indiana, using 3 study sites of different ages. In contrast to Verts (1957), he did not focus on any particular small mammal species, but instead tried to examine the full range of small mammal fauna. However, the only additional species he captured in significant numbers was prairie vole (Microtus ochrogaster). His results were similar to those of Verts (1957) in that more recently mined areas had higher overall small mammal abundances than areas that had been less recently mined. The white-footed mouse 
appeared to select wooded areas, and the prairie deer mouse and prairie vole selected areas with little or no woody cover. Wetzel (1958), Hansen and Warnock (1978) and Urbanek and Klimstra (1986) also worked on Illinois strip mines. All 3 studies had results that were in concurrence with the studies mentioned above: small mammal abundance was higher on recently mined areas than on older areas, white-footed mouse abundance was higher in forests than mined areas, and prairie deer mouse abundance was higher in reclaimed grasslands than forests. McGowan and Bookout (1986) took a slightly different approach; they compared small mammal populations between mined areas that had been reclaimed under different regulations in Ohio. Their goal was to assess whether changes in surface mine reclamation practices following the passage of more stringent legislation in 1972 had affected small mammals. They examined 3 previously mined areas, 2 reclaimed after and 1 reclaimed before the law change. Their results suggested that small mammals were present in greater abundance on areas that had been reclaimed after 1972 than on areas reclaimed before 1972. However, their study results were confounded by the fact that the sites on which the more stringent rules were followed had been reclaimed approximately 10 years after the site that followed the old reclamation laws, so the small mammal density difference may have been related, in part, to temporal differences in succession.

\section{Small Mammals on Reclaimed Mines vs. Undisturbed Habitat}

Results from studies that compare small mammals on reclaimed mines with nearby undisturbed habitat may be more relevant to my study, as I did not aim to evaluate the changes in small mammal abundance and species composition as a function of time since reclamation. Kirkland (1976) examined open-pit ilmenite and magnetite ore mines in the Adirondack Mountains of New York. His approach was comparable to mine since he sampled small mammals on reclaimed mines (from 1-20 years old) and compared these results to small 
mammal populations in nearby intact forests. He found a significant difference in species richness between the 2 areas; 13 species were captured in intact forest, and only 7 were captured on previously mined sites. The intact forests also had higher small mammal abundance, with the deer mouse the only species represented in significant numbers on the mined areas. Wetzel (1958) compared previously mined floodplain forests over a 15-year period with mature and climax floodplain forests and found that overall abundance was as high or higher in these unmined areas than in any of the different ages of mined land. He captured 12 species on mined sites and only 9 on unmined lands, presumably because mined lands provided a wider array of habitats ranging from open grasslands to early-successional forest.

De Capita and Bookout (1975) compared mined to unmined areas in Ohio. They found higher abundance of Peromyscus species, meadow vole, and raccoon on previously mined lands than on unmined lands. Other species, such as short-tailed shrew (Blarina brevicauda), opossum (Didelphis virginiana), groundhog (Marmota monax), eastern cottontail (Sylvilagus floridanus), and eastern chipmunk (Tamias striatus) were present in higher numbers on unmined lands. Species richness was lower on coal spoils than on unmined land, and the authors concluded that spoils provided inferior habitat. Unmined lands, in this study, included 3 different habitats: old field, old field-pine, and deciduous woods. Mined land also was of three types: brush hardwoods, hardwoods, and non-vegetated. Similar treatments on mined and unmined land were not compared separately.

Voight and Glenn-Lewin (1979) compared small mammal richness and abundance between mined and unmined land in Iowa. Like De Capita and Bookout (1975), they included forested and non-forested habitats for both mined and unmined land, combining the different stages of succession in their analysis. More species were captured on unmined than on mined 
lands and Peromyscus spp. dominated both mined and unmined early-successional lands.

Peromyscus spp. had shorter breeding seasons on mined sites, and the authors speculate that this was due to decreased cover and food supply on mines.

Urbanek and Klimstra's (1986) study also yielded results that are comparable to those of my study. Although they did not trap a control (relatively large and intact) forest, they evaluated the small mammal abundance and species richness indices that they found on reclaimed mines in Illinois to those of a previous study conducted on unmined areas near their sites (Terpening et al. 1975). This comparison indicated that small mammal abundance was higher on the mined sites than the intact forests and that species richness was not different between the 2 areas. However, small mammal abundance can vary temporally (both yearly and seasonally), so differences in abundance may be due to temporal rather than habitat differences.

\section{Studies Conducted on West Virginia Mines}

Mindell (1978) trapped small mammals to assess coal mines as raptor habitat in Monongalia County, West Virginia and Green County, Pennsylvania. Using snap traps on reclaimed mines ranging in size from 0.7 to 40 hectares and forests adjacent to mines, he captured 5 species. Meadow voles (Microtus pennsylvanicus) were the most common, representing about $70 \%$ of the total. Other species captured were short-tailed shrew, whitefooted mice, deer mice, and meadow jumping mice (Zapus hudsonius). He combined the 2 Peromyscus species for analyses because they are difficult to differentiate in this part of their range. Though these 5 species were all found on reclaimed sites, some were more common in either reclaimed areas or forest. For example, Peromyscus species were more common in forest whereas meadow vole abundance was greater in reclaimed areas. Mindell (1978) also found that combined small mammal abundance was higher on reclaimed mines than in forests, and that 
there was a significant positive correlation between litter depth and small mammal abundance among all treatments. His study, however, aimed to assess abundance of small mammals as a potential prey base for raptors, so richness was not calculated nor compared between treatments. Forren (1981) also looked at small mammals in Monongalia County, West Virginia as prey for raptors on several strip-mined areas that had been reclaimed between 1971 and 1976 and ranged in size from 16 to 27 ha; however, he did not trap in forested areas. He found the same 5 species as Mindell (1978) with meadow voles representing 56.8\% of the total. Like Mindell (1978), Forren (1981) determined that there was a significant positive correlation between litter depth and small mammal numbers.

Amrani (1987) compared small mammal populations on surface mine cattail (Typha spp.) marshes with populations on nearby reclaimed grasslands in West Virginia. She found that Peromyscus (P. leucopus and P. maniculatus combined) abundance and overall small mammal abundance were greater in marshes than in grasslands, concluding that the marsh may provide a more favorable microclimate during weather extremes such as the heat of summer (McConnell and Samuel 1985). There was, however, no difference in abundance of meadow voles between the 2 treatments. Short-tailed shrews, meadow jumping mice, and house mice (Mus musculus) also were captured, but too infrequently for statistical comparisons.

Yearsley and Samuel (1980) conducted a study in Preston County, West Virginia on red and gray fox use of reclaimed mine habitats. They found that fox use of mines varied seasonally, with higher use in the fall, winter, and spring than summer. The authors speculated that seasonal differences occurred because foxes feed primarily on small mammals when fruits and berries are not available, and small mammal populations were higher on the mines than in the surrounding forest. They felt that this hypothesis was supported by several observations of foxes hunting for 
mice on mines during these periods of high use. However, they did not sample small mammal populations.

\section{Small Mammals and Forest Fragmentation}

Numerous studies have examined the effects of forest fragmentation on small mammals (Gottfried 1977, Yahner 1986, Yahner 1992, Nupp and Swihart 1996, Rosenblatt et al. 1999). Gottfried (1977) compared small mammal abundance and diversity between woodlot islands and large forest tracts in eastern Iowa, and found a positive relation between forest area and small mammal diversity and abundance. Larger forest islands may have higher diversity because they can support a larger, more stable population thus lowering the chance of a species becoming locally extinct (Hanski 1996). A second possibility is that larger forest patches are more likely to contain greater diversities of microhabitats, allowing more species to coexist (MacArthur and Wilson 1967, Gotelli 1998). A positive mammalian diversity to forest area relation also was found by Rosenblatt et al. (1999) in a study of Illinois forest patches ranging from 1.8 to 600 ha. They did not limit their study to just small mammals; instead, they looked at all mammals except bats. Sciurid species such as gray squirrels (Sciurus carolinensis), southern flying squirrels (Glaucomys volans), and eastern chipmunks only were found in larger islands of forest; they did not report whether small mammal abundance differed between large and small patches.

Nupp and Swihart (1996) studied white-footed mice in Indiana, comparing populations in 15 woodlots of various sizes to 3 continuous forests. They found higher densities in small woodlots as well as an inverse relation between mass of adult male mice and forest patch size. They speculated that small woodlots may have higher food availability since trees and shrubs may be more productive at forest edges, leading to a greater supply of seeds. Also, they note that sciurid species are generally absent from small woodlots, releasing the white-footed mouse from 
competition for mast during autumn and winter. These results are the opposite of what Yahner (1986) found in a study of the spatial distribution of white-footed mice on a forested landscape fragmented by clearcuts in Pennsylvania. His study suggested that white-footed mice strongly select interior zones of forests, possibly due to differences in predation pressures or food abundance between the forest interior and the edge zones. In a later study, Yahner (1992) examined the effects of habitat fragmentation due to forestry on small mammals in Pennsylvania, trapping on sites classified as $25-, 50-$, and $75 \%$ fragmented. He found that the white-footed mouse became significantly more abundant as percent fragmentation increased.

Kirkland (1977) conducted a study on the Monongahela National Forest in West Virginia in which small mammals were sampled in clearcuts of varying ages and successional stages. He found that there was an immediate increase in abundance and diversity of small mammals following timber harvesting, and that the effect persisted until succession reached the sapling/pole forest stand. The shift was interpreted as a response to the decrease in herbaceous layer caused by young trees shading the forest floor. Root (1990) performed a similar study in Missouri. He targeted P. leucopus and found greater abundances in recent clearcuts than in uncut forests.

\section{Allegheny Woodrats}

\section{Background}

The Allegheny woodrat is a medium-sized rodent, resembling a large white-footed mouse with grayish-brown dorsal pelage, white underparts, and a fur-covered tail (Hall 1985, Whitaker and Hamilton 1998). It typically inhabits rock structure of many sorts, including rock outcrops, cliffs, talus slopes, limestone caves, and boulder piles (Rhoads 1894, Newcombe 1930, Poole 1940, Pearson 1952, Hall 1985). Nests of sticks, bark, vines, and leaves are constructed within 
the inaccessible interstitial spaces of such habitat, providing protection from the elements and escape from predators (Wiley 1980). Newcombe (1930) described the typical nest found in West Virginia as being open at the top and shaped like a robin's nest with a diameter of about $250 \mathrm{~mm}$ and a depth of $75 \mathrm{~mm}$; they were well constructed of fibers from chestnut (Castanea dentata) and basswood (Tilia hetrophylla) and he believed them to have been used by previous generations. A wide variety of plant material, mast, and fungi are eaten by woodrats, and gathered food items, along with piles of sticks, leaves, and bark, are cached in middens near nests (Newcombe 1930, Hall 1985, Wagle and Feldhammer 1997, Castleberry 2000a). Another typical sign of woodrat presence are latrines often prominently located on flat rocks. Poole (1940) found latrine sites with dimensions up to $457 \mathrm{~mm}$ long, $305 \mathrm{~mm}$ wide, and $50 \mathrm{~mm}$ deep, indicating that sites are used by a number of rats for a long period of time. This habit is apparently for sanitary purposes, as woodrats in captivity also tended to drop feces in the same spot, in remote corners of cages (Poole 1940).

Allegheny woodrats are closely related to eastern woodrats ( $N$. floridana), but were classified as a species when Goldman (1910) revised the genus Neotoma. This designation was questioned by Burt and Barkolow (1942) based on an examination of bacula. N. magister was designated a subspecies of $N$. floridana 15 years later when Schwartz and Odum (1957) argued that morphological characteristics of $N$. magister and $N$. floridana show gradual variation on a north-south cline with no clear break between the two. Hayes and Richmond (1993) found that when size as a function of latitude was compared between N. magister and non-magister specimens for 16 characteristics (males and females compared separately), N. magister was significantly larger in 30 of the 32 comparisons. In addition, Hayes and Harrison (1992) inferred from mitochondrial DNA analysis that $N$. magister and $N$. floridana were reproductively 
isolated. This work led to the Allegheny woodrat being restored to species status, a designation with which subsequent genetic research has concurred (Planz et al. 1996).

Allegheny woodrats have historically ranged along the Appalachian Mountains from southern New York to northern Alabama and west into Kentucky, Ohio, and Indiana (Poole 1940, Hall 1985, Balcom and Yahner 1996). Today, the species is no longer found in New York, has experienced drastic declines in New Jersey and eastern Pennsylvania, and is listed as threatened, endangered, or as a species of special concern in Indiana, Maryland, New Jersey, New York, North Carolina, Ohio, Pennsylvania, Virginia, and West Virginia (Kirkland and Krim 1990, Beans 1992, Castleberry 2000b). Population declines have been most precipitous at the northern and western edges of its range; West Virginia, at the center of its geographical distribution, appears to be a stronghold with fairly stable populations, although the official status of woodrats in West Virginia is unknown as surveys statewide have not been conducted (Mengak 1996, Stihler and Wallace 1996).

The reason for woodrat decline is uncertain, but may be due to a variety of factors. Exposure to the ascarid roundworm (Baylisascaris procyonis) carried by raccoons (Procyon lotor) has reduced woodrat populations in some northern states (Hicks and McGowin 1996). Habitat fragmentation has led to an increase in raccoon populations, and presumably an increase in woodrat contact with raccoons and their feces. Increased avian predation may also have caused declines in woodrat populations, especially by great horned owls (Bubo virginianus), which have benefited from fragmentation due to urbanization, forestry, and agriculture (Balcom and Yahner 1996). Another factor may be the decrease in available hard mast due to the chestnut blight (Cryphonectria parasitica), gypsy moth (Lymantria dispar) defoliation, and the decline in 
oak (Quercus spp.) abundance (Balcom and Yahner 1996, Castleberry 2000b). It is likely that these factors and perhaps others have worked together to cause the decrease in woodrat numbers.

\section{STUDY ORGANIZATION}

This thesis is organized into 4 chapters. Chapter 1 is an introduction providing general information on MTMVF operations and a review of literature on small mammals on reclaimed and fragmented forest landscapes and on Allegheny woodrats. In Chapter 2, I present results of small mammal trapping on MTMVF and intact forest sites using Sherman live traps and pitfall and funnel traps associated with drift fence arrays. This chapter compares the abundance and richness of small mammals on 2 ages of reclaimed sites, fragmented forest, and intact forest sites. Special attention is paid to Peromyscus spp. as they were the predominant capture, and the

only species captured frequently enough to analyze demographic parameters. The $3^{\text {rd }}$ chapter is a description of the reclaimed drainage channel habitat in which Allegheny woodrats were captured during my study. Drainage channel characteristics are also compared to typical woodrat habitat characteristics. Chapter 4 is a brief synopsis of the management implications of my study. 


\section{CHAPTER 2 - SMALL MAMMAL RICHNESS AND ABUNDANCE ON A RECLAIMED MOUNTAINTOP MINE LANDSCAPE IN SOUTHERN WEST VIRGINIA}

\section{ABSTRACT}

The mountaintop mine/valley fill (MTMVF) method of coal mining, used since the late 1960s in southern West Virginia, is an efficient, large-scale form of strip mining. Effects of this mining method on small mammal communities have not been examined. Small mammals were captured by Sherman live trap during the summers of 1999 and 2000 and by pitfall and funnel traps associated with drift fence arrays from spring-fall in 2000 and 2001 on 3 treatments representing the post-mining landscape (grasslands, shrub/pole stands, fragmented forests) and intact forests representing the pre-mining condition. A total of 1,096 individuals of 12 species were captured with Sherman traps during 11,160 trap nights; 1087 individuals of 13 species were captured during 12,842 drift fence array trap nights. Peromyscus species (P. leucopus and P. maniculatus) dominated Sherman trapping ( $87 \%$ of captures) and were the most common capture in drift fence traps (37\%). Reclaimed areas appeared to provide superior habitat for Peromyscus spp. based on abundance and demographic data. Eastern chipmunks (Tamias striatus), woodland jumping mice (Napaeozapus insignus), woodland voles (Microtus pinetorum), short-tailed shrews (Blarina brevicauda), and pygmy shrews (Sorex hoyi) were generally more common in forest treatments, whereas house mice (Mus musculus), southern bog lemmings (Synaptomys cooperi), and masked shrews (S. cinereus) were generally more common in reclaimed treatments. Smoky shrews (S. fumeus) and meadow voles (M. pennsylvanicus) did not show abundance differences among treatments. Allegheny woodrats (Neotoma magister) were an unexpected capture in Sherman traps near reclaimed drainage channels in shrub/pole treatment. Most results were consistent with published literature as Peromyscus spp. abundance generally is 
higher in earlier stages of succession. Other species were generally present in expected habitats. The use of reclaimed drainage channels by Allegheny woodrats was not found in published literature, but rip-rap boulders form deep interstitial networks that may simulate the rock outcrops that are their typical habitat.

\section{INTRODUCTION}

Small mammals are an important component of biological diversity, and their populations are affected by forest fragmentation (Gottfried 1977, Yahner 1986, Yahner 1992, Nupp and Swihart 1996, Rosenblatt et al. 1999). They are the primary prey base for a variety of mammalian and avian predators (Mindell 1978, Yearsley and Samuel 1980, McGowan and Bookout 1986); thus, changes in their abundance can affect other species. Additionally, small mammals are ecologically important as predators, herbivores, and detritivores, and seed dispersers (Mumford and Bramble 1973, Bayne and Hobson 1998). Consequently, it is important to document the effects of large-scale habitat changes on small mammal communities.

In southern West Virginia, MTMVF operations convert large expanses of deciduous forest to early-successional habitats. Mine operations move along ridgelines, removing soil and rock (spoil) to gain access to coal seams. A portion of the spoil is placed into nearby valleys; the remainder is piled back onto ridgelines after coal is removed to restore the approximate original contour. This type of operation occurs on a much larger scale than other types of mining with resulting reclaimed land areas of $25 \mathrm{~km}^{2}$ or more.

Although I found no previous studies of small mammal populations on MTMVF landscapes, there have been several studies of small mammals on strip-mined lands throughout the coal mining regions of the mid-western and eastern United States (Verts 1957, De Capita and Bookout 1975, Sly 1976, Hansen and Warnock 1978, Urbanek and Klimstra 1986, McGowan 
and Bookout 1986). Several of these found that small mammal communities on mines differ as a function of time since mining activity (Verts 1957, Sly 1976, Hansen and Warnock 1978, McGowan and Bookout 1986). Mumford and Bramble (1973) reported high densities of Peromyscus on reclaimed land. Four studies compared small mammal populations on reclaimed lands with those on unmined areas (De Capita and Bookout 1975, Kirkland 1976, Voight and Glenn-Lewin 1979, Urbanek and Klimstra 1986). Abundance was higher on reclaimed land in 3 of these studies. Unmined lands in 2 of these studies included habitats other than intact forests, which may make comparisons with my study difficult. All of these studies occurred on sites considerably smaller than typical MTMVF operations; consequently, additional research is needed to clarify the effects of MTMVF on small mammal populations. This study aimed to fill this gap by accomplishing the following objectives:

1) quantify and compare small mammal species richness and abundance on 3 treatments representing the post-mined landscape (grassland, shrub/pole, and fragmented forest) and one representing the pre-mined landscape (intact forest),

2) determine if differences in small mammal abundance and species richness could be explained by differences in microhabitat, and

3) examine demographic parameters of Peromyscus spp. to assess habitat quality among the 4 treatments.

\section{STUDY AREA}

Study areas were located on 3 MTMVF complexes in southern West Virginia: the Hobet 21 mine (2431 ha) in the Mud River watershed in Boone County about $40 \mathrm{~km}$ southwest of Charleston; the Dal-Tex mine (1925 ha) in the Spruce Fork watershed in Logan County about 25 $\mathrm{km}$ north of the town of Logan; and the Cannelton mine (2180 ha) in the Twenty-mile Creek 
watershed on the border of Kanawha and Fayette Counties about $50 \mathrm{~km}$ southeast of Charleston (Appendix B).

Small mammals were sampled in 4 treatments; intact forest represented the pre-mining landscape while fragmented forest, shrub/pole, and grassland represented the post-mining landscape. The grassland treatment included areas reclaimed 7-21 years (mean $=13.9$ years) prior to my study; they ranged from $327-434 \mathrm{~m}$ in elevation (mean $=369 \mathrm{~m}$ ). Grasslands, dominated by grass and herbaceous species, included some shrub and tree seedlings and patches of bare ground. Major species planted in the reclamation process were tall fescue (Festuca arundinacea), sericea (Lespedesa cuneata), autumn olive (Elaeagnus umbellata), black locust (Robinia pseudoacacia), European black alder (Alnus glutinosa), and scotch pine (Pinus sylvestris). The shrub/pole treatment consisted of mined areas reclaimed 18-28 years (mean $=$ 21.1 years) prior to my study with elevations of $310-416 \mathrm{~m}($ mean $=357 \mathrm{~m})$. These areas were reclaimed with many of the same species as the grasslands, and they maintained a grass component along with significant patches of goldenrod (Solidago spp.) and sericea. Small trees and shrubs dominated these areas, especially red maple (Acer rubrum), American sycamore (Platanus occidentalis), yellow-poplar (Liriodendron tulipifera), multiflora rose (Rosa multiflora), and blackberry/raspberry (Rubus spp.). Fragmented forest treatments were strips of woods along second-order streams surrounded by reclaimed lands on three sides; the width of fragmented forest ranged from 92-842 $\mathrm{m}($ mean $=356 \mathrm{~m})$ at small mammal transects, while elevation ranged from 253-376 $\mathrm{m}($ mean $=312 \mathrm{~m})$. Fragmented forests consisted primarily of mature hardwood tree species, such as northern red oak (Quercus rubra), white oak (Q. alba), yellow-poplar, American beech (Fagus grandifolia), red maple, sugar maple (A. saccharum), pignut hickory (Carya glabra), bitternut hickory (C. cordiformis), shagbark hickory (C. ovata), 
white ash (Fraxinus americana), and black birch (Betula lenta). Intact forest treatments were relatively large tracts of woods near mine complexes; their elevations were between 288-552 m $($ mean $=363 \mathrm{~m})$. These also were mature hardwoods, with similar tree species composition to fragmented forest.

\section{METHODS}

\section{Sherman Trapping}

Transects 150-m long were established within each treatment based on a random selection of points spaced $250 \mathrm{~m}$ apart established for riparian songbird surveys in a related study (Wood et al. 2000). Transects were located within $10 \mathrm{~m}$ of streams, or, in the case of reclaimed sites, rock drainage channels. These areas were chosen to maximize the number of species and individuals captured as riparian areas often have higher small mammal richness (Stamp and Ohmart 1979, Doyle 1990) and abundance (Gomez and Anthony 1998, Bellows and Mitchell 2000) than adjacent upland areas. Transects followed a constant bearing for as long as the stream or drainage channel allowed, occasionally crossing the waterway as it meandered. Transect bearing changed only when drastic bends in the stream or reclaimed drainage channel required it. Trapping stations were placed at 10-m intervals along each transect line, with two Sherman live traps $(7.7 \times 9 \times 23 \mathrm{~cm})$ set within $2 \mathrm{~m}$ of each station, for a total of 30 traps per line. Traps were baited with a mixture of rolled oats and peanut butter. These procedures followed the protocol established by Jones et al. (1996).

In 1999, 24 transects were sampled on Hobet $21(n=18)$ and Daltex $(n=6)$ mines, with 8 transects in each of 3 treatments (grasslands, fragmented forests, and intact forests). In 2000, trapping effort was expanded to 36 transect lines by adding a third MTMVF complex (Cannelton) and a fourth treatment (shrub/pole). The 36 transects included 10 in grasslands, 6 in 
shrub/pole, 10 in fragmented forests, and 10 in intact forests (22 on Hobet 21, 6 on Daltex, and 8 on Cannelton).

In 1999, the 24 transects were divided into 4 trapping blocks of 6 transects. Each block contained 2 transects from each of the 3 treatments. In 2000, the 36 transects made up 5 trapping blocks: 3 blocks consisted of 8 transects with 2 from each of the 4 treatments and 2 blocks consisted of 6 transects with 2 from each treatment except shrub/pole. The shrub/pole treatment was not represented equally as it was not present in equal proportion to the other treatments and was virtually absent from the Daltex mine. Transects within each block were trapped concurrently to minimize temporal variability for within-block comparisons. Each block contained transects located as close to one another as the landscape allowed to minimize spatial differences. Traps were prebaited for 1 night prior to being set; they were then opened for 3 consecutive nights and checked between 0700 and 1200 hours each day of trapping to minimize mortality of animals captured. Traps were moved weekly to a new block until each block had been trapped twice from mid-May to mid-August in 1999 and 2000.

Captured animals were weighed, sexed, and examined for reproductive status, and then released at the point of capture. Animals were identified to species except for the Peromyscus species of mice (P. leucopus and P. maniculatus) which were grouped together due to the difficulty in distinguishing one from the other (Wolff 1985, Rich et al. 1996). All individuals except shrews (B. brevicauda and Sorex spp.) were marked with numbered metal ear tags before release; shrews were marked by toe clipping. Any individuals that died in the traps were saved as voucher specimens. Trapping and handling procedures were approved by the West Virginia University Animal Care and Use Committee (ACUC\# 9904-10). 


\section{Drift Fence Array Trapping}

During 2000 and 2001, small mammals also were trapped in pitfall and funnel traps associated with drift-fence arrays established to target herpetofauna (Wood et al. 2000). Driftfence arrays complement Sherman-trapping because they are effective at capturing the shrews that are uncommon captures in live traps (Szaro et al. 1988, Blackburn and Andrews 1992, Kirkland 1994). Four 15-m sections of 30-cm tall plastic silt fencing supported by wooden stakes (Enge 1997) were installed to form a plus (+) shape with $15 \mathrm{~m}$ of central separation, a design that is effective at intercepting animals traveling in any direction (Campbell and Christman 1982, Corn 1994). An 18.9-L plastic bucket (pitfall trap) was buried flush with the surface at the end of each individual drift fence (Campbell and Christman 1982, Vogt and Hine 1982, Pais et al. 1988, Corn 1994). Wet sponges were placed in the bottom of each trap to prevent desiccation of herpetofauna. Funnel traps (minnow trap \#1275, Frabill, Jackson, Wisconsin) were placed on opposite sides of each drift fence at the midpoint (Campbell and Christman 1982, Vogt and Hine 1982, Bury and Corn 1987, Pais et al. 1988, Corn 1994).

Array centers were positioned $35 \mathrm{~m}$ from a stream or rip-rap drainage channel. Three arrays were established in each treatment, with 2 in the Spruce Fork watershed (Daltex Mine), 5 in the Mud River watershed (Hobet 21 Mine), and 5 in the Twentymile Creek watershed (Cannelton Mine). Monthly trapping sessions ranged from 5-12 days; 13 sessions were conducted between March - October in 2000 and 2001. Traps were visited every other day while they were open (Campbell and Christian 1982, Vogt and Hine 1982, Corn 1994), and the number of non-functioning traps was recorded for each night. Most live mammals were identified to species, although some shrews (Sorex spp.) and voles (Microtus spp.) could be identified only to genus. Live animals were marked with a spot of Wite-OutC Correction Fluid (MIM Bic Corp., 
Milford, Connecticut 06460) so that individuals recaptured during a trapping session could be identified and were released $3 \mathrm{~m}$ from the drift fence array (Campbell and Christian 1982, Vogt and Hine 1982). Dead animals were collected and later identified to species.

\section{Habitat Data Collection}

Vegetation subplots were established and sampled at $35 \mathrm{~m}$ and $105 \mathrm{~m}$ along each Sherman trapping transect, at the center of each drift fence array, and $35 \mathrm{~m}$ from the center of drift fence arrays at azimuths of $0^{\circ}, 120^{\circ}$, and $240^{\circ}$. Sampling methods modified from James and Shugart (1970) and Martin et al. (1997) were used. A 0.04-ha circle was established at each subplot by laying out $222.6-\mathrm{m}$ ropes perpendicular to each other and crossing at the center. The ropes delineated the transects for sampling. Within this circle, individual trees were identified and placed into 1 of 2 categories based on diameter-at-breast-height (DBH): 8-38 cm, and $>38$ $\mathrm{cm}$. Shrub and sapling stems $(<8 \mathrm{~cm} \mathrm{DBH})$ were counted within a 5-m radius circle nested within the 11.3-m radius circle (Martin et al. 1997). Percent ground and canopy cover were estimated using an ocular sighting tube (James and Shugart 1970) by sighting at the ground and upward at the canopy at $2.3-\mathrm{m}$ intervals along each rope. Ground cover was recorded as green (includes grass, shrubs, ferns, and herbaceous vegetation $<0.5 \mathrm{~m}$ in height), bare ground/rock, woody debris, water, or leaf litter. Canopy cover was recorded as present or absent within 4 height classes (determined by visual estimation) representing the different canopy layers: 0.5-3 $\mathrm{m},>3-6 \mathrm{~m},>6-12 \mathrm{~m},>12 \mathrm{~m}$. Aspect, slope, canopy height, and distance to nearest habitat edge were recorded. Habitat edges included small-scale disturbances, such as roads or small openings, or changes in habitat structure, such as forest/grassland or mature forest/pole forest interfaces. 
Grassland vegetation also was measured based on BBIRD protocols (Martin et al. 1997). Ground cover, aspect, slope, and distance to nearest edge were recorded as with the forest points. A Robel pole (Robel et al. 1970) was used to record an index of plant biomass at the plot center and at intervals of 1.0-, 3.0-, and 5.0-m from the center along each transect in the 0.04 -ha plot. Litter depth was measured with a metric ruler at these same points.

\section{Statistical Analyses}

\section{Sherman Trapping Data}

Relative abundance of small mammals was calculated as the number of individuals captured per 100 trap nights, with recaptures excluded. Abundances were calculated for each species individually and for all small mammals combined. Trap nights were adjusted by subtracting one-half trap night for each trap sprung for any reason, including the capture of an animal (Nelson and Clark 1972, Beauvais and Buskirk 1999) and for each trap found open but without bait. Species richness was calculated as the number of species captured per transect.

Demographic parameters for Peromyscus spp. were calculated as additional means of assessing differences in habitat quality among treatments because the number of individuals present is often not a reliable indicator of habitat quality (Van Horne 1983). Abundances of age and sex groups (adult male, adult female, juvenile male, and juvenile female) per 100 trap nights and adult/juvenile ratios were calculated. Also, the percentage of adult Peromyscus spp. individuals in reproductive condition for each treatment was calculated, where mice weighing 16 g or more were considered adults (Whitaker and Hamilton 1998). Males were considered reproductive if their testes were descended and females were considered reproductive if they were pregnant, nursing, or their nipples showed evidence of past lactation (McCravy and Rose 1992). 
A randomized block analysis of variance (ANOVA) was used to compare species richness, total small mammal abundance, species-specific abundance, Peromyscus spp. age and sex group abundance, and percentage of individual Peromyscus spp. in reproductive condition among treatments. Concurrently trapped transects were considered blocks for this model since temporal and spatial factors were minimized by the design. If differences between treatments were detected by the ANOVA, a Waller-Duncan k-ratio $t$-test multiple comparison procedure was used to compare means (Zar 1999). ANOVA also was used to compare species richness, total small mammal abundance, species-specific abundance, and the percentage of individuals in reproductive condition among treatments between the 2 years of the study. Sources of variation and descriptions of independent variables for each ANOVA model are found in Appendix A Tables A. 1, A. 2, and A. 3. Statistical results were considered significant at $P \leq 0.05$. Analysis also was conducted to determine if the time since reclamation affected species richness, total abundance, and Peromyscus abundance. Richness and abundance were plotted against the number of years since reclamation occurred, and the relation tested with Pearson product-moment correlation (Zar 1999). Correlation coefficients were considered significant at $P \leq 0.05$. All statistical analyses were completed with the Statistical Analysis System (SAS Version 8, SAS Institute, Inc. 1998).

\section{Drift Fence Array Data}

Overall small mammal abundance and species-specific abundances were calculated as the number of individuals captured per 100 array nights adjusted for non-functioning traps and with recaptures excluded. Richness was calculated as the number of species per session at each array. Mean abundance and richness were compared among treatments with ANOVA using treatment, trapping session, and the interaction between treatment and trapping session as independent 
variables (Appendix A Tables A. 4 and A. 5). If the ANOVA found that means were different, a Waller-Duncan k-ratio $t$-test was used to compare means among treatments (Zar 1999). Statistical results were considered significant at $P \leq 0.05$.

\section{Analysis Conducted on Sherman and Drift Fence Array Data}

Jaccard and Renkonen indices were used to determine the degree of similarity of the species composition between pairs of treatments (Nur et al. 1999). Each of these indices measures the species overlap between 2 communities on a relative scale from 0 to 1 . The Jaccard index uses the number of shared species between 2 habitats to gauge similarity, while the Renkonen index incorporates the abundance of each species as well (Nur et al. 1999).

For Peromyscus spp. abundance, overall small mammal abundance, and species richness, a stepwise multiple linear regression procedure was used to identify important habitat or environmental characteristics. The partial $R^{2}$ for each independent (habitat or environmental) variable identified in multiple regression was reported as well as the overall $R^{2}$ for the model. The partial $R^{2}$ indicates the amount of variation in the dependent variable (richness or abundance) for which the independent variable accounted; model $R^{2}$ indicates the amount of variation in the dependent variable accounted for by all independent variables identified as significant. For species that were captured less frequently, stepwise logistic regression was used on presence/absence data to identify important habitat and environmental variables. The Wald $\mathrm{X}^{2}$ statistic tests the contribution of each independent variable identified as significant to species presence/absence and the Hosmer-Lemeshow Goodness-of-Fit (HLGF) statistic tests the null hypothesis that the data fit the model. An HLGF $P$-value $\leq 0.05$ indicates that the data do not fit the model (Cody and Smith 1997); higher values of this statistic suggest a better fit. In both multiple and logistic regression, an entry level of 0.30 and a stay level of 0.10 was used. 
Variables expressed as percentages were arcsine-square-root transformed to improve normality before running the regression (Zar 1999). Aspect, recorded as an azimuth from $0^{\circ}$ to $360^{\circ}$, was transformed by the function $(\cos [45-\mathrm{x}]+1)$ to make it an independent variable (Beers et al. 1966).

Environmental variables were incorporated into the regression models because they can affect small mammal activity and capture probabilities (Vickery and Bider 1981, Vickery and Rivest 1992). They included precipitation (cm) (National Oceanic and Atmospheric Administration/National Weather Service, Charleston, WV) (van Hensbergen and Martin 1993) averaged over each trapping session, low temperature $\left({ }^{\circ} \mathrm{C}\right)(\mathrm{NOAA} / \mathrm{NWS}$, Charleston, WV), moon phase expressed as a percentage of moon's surface illuminated (Astronomical Applications Department, US Naval Observatory) (Travers et. al 1988), and an index of nighttime ambient light (Castleberry 2000b). The ambient light index was calculated as a product of the percentage of the moon's surface illuminated and cloud cover (NOAA/NWS, Charleston, WV) on a scale of 1 (clear skies) to 0.1 (overcast). The grassland treatment was analyzed separately from the other three treatments in the regression procedures because different habitat variables were recorded. In addition, regressions were performed on data from fragmented forest and intact forest treatments to identify habitat and environmental variables that were important to species found primarily in these treatments.

\section{RESULTS}

A total of 1,096 individuals of 12 species were captured during 11,160 trap nights (before correction) of Sherman trapping while 1,087 individuals of 13 species were captured during 12,842 trap nights of drift fence array trapping. Peromyscus spp. were the predominant capture, accounting for 949 individuals by Sherman trap (87\% of total) and 398 individuals (37\%) by drift fence array trap. The 3-night Sherman trapping period appeared to successfully sample 
Peromyscus spp. populations because $79 \%$ of individuals captured on the third night were recaptures from the first two nights (Batzli 1977). Initial ANOVA models included 1999 and 2000 Sherman data, but interaction terms of treatment and year were significant in every case. Consequently, for all statistical analyses comparing Sherman trapping data among treatments with ANOVA, data were analyzed separately for each year. Year by treatment interaction terms for drift fence data were not significant $(\mathrm{F}=1.00, d f=3, P=0.3961)$, so 2000 and 2001 data were combined in ANOVA models comparing treatments.

\section{Species Richness and Community Composition}

Species richness did not differ among treatments based on Sherman data, while the intact forest treatment had lower richness than the other 3 treatments based on array data (Table 1). The intact forest treatment had a significant change in richness based on Sherman data from 1999 to 2000, decreasing from 2.3 to 1.4 species per transect (Table 2). Overall, 12 species were captured by Sherman trap during the study, with 8 in grassland, 4 in shrub/pole, 6 in fragmented forest, and 6 in intact forest. Thirteen species were captured by drift fence array traps, with 10 in grassland, 9 in shrub/pole, 10 in fragmented forest, and 9 in intact forest.

When all possible pairings of treatments were compared for small mammal species composition within each year, Jaccard indices ranged from 0.13 to 0.90 (Table 3) on a scale from 0.0 (no similarity) to 1.0 (complete similarity). Based on Sherman trapping, the most similar pair was the fragmented forest and the intact forest in 1999 while the least similar was the shrub/pole and fragmented forest treatment in 2000. Based on array trapping, the shrub/pole treatment and either fragmented forest or grassland were the most similar pair, while grassland and intact forest were the least similar pair. Renkonen indices ranged from 0.54 to 0.93 on the 
same scale of 0.0 to 1.0 , with shrub/pole and grassland the most similar pair based on either trapping method. Based on array trapping, grassland and intact forest was the least similar pair.

\section{Abundance}

Total small mammal abundance and Peromyscus spp. abundance based on Sherman trapping did not differ among the 3 treatments sampled in 1999, but was significantly higher in the grassland and shrub/pole treatments than fragmented and intact forest treatments in 2000 (Table 1). Based on array data, total small mammal abundance was lower in the intact forest treatment than in the other 3 treatments, while Peromyscus spp. abundance was significantly lower in intact forest than in grassland and shrub/pole.

Eastern chipmunks were captured almost exclusively in Sherman traps and were significantly more abundant in intact forest than in other treatments (Table 1). Three species of microtine rodent were captured almost exclusively in drift fence traps: southern bog lemmings, woodland voles, and meadow voles. Southern bog lemmings were the most common microtine, and they were more abundant in the two reclaimed treatments than in the fragmented forest treatment, while they were not captured at all in the intact forest. Woodland voles were more abundant in intact forests than in grasslands, and meadow voles did not differ in abundance among treatments.

Other rodent species captured included woodland jumping mice, house mice, and Allegheny woodrats. Woodland jumping mice were more abundant in fragmented forest than in other treatments based on array data. Based on Sherman data, house mice were captured only in the grassland treatment, while Allegheny woodrats were captured only in the shrub/pole treatment (Table 1). 
In 1999, Sherman-trapped northern short-tailed shrews had a higher abundance in intact forest than in grasslands, while, in 2000, they were captured too infrequently for statistical analysis (Table 1). Short-tailed shrew abundance based on drift fence trapping was greater in fragmented forest than in the other 3 treatments. Three other shrew species were captured by drift fence arrays, with masked shrews being the most common. Masked shrews were more abundant in the grassland and shrub/pole treatments than in the intact forest or fragmented forest treatments. Smoky shrews and pygmy shrews were less commonly captured and neither differed in abundance among treatments.

Several between-year differences in small mammal abundance were detected based on Sherman trapping. Both total abundance and Peromyscus species abundance increased significantly in grassland habitats from 1999 to 2000 (Table 2). Abundance of other grassland species declined in 2000, although sample sizes were too small for statistical analyses (meadow

vole, Table 1) or to detect a statistical significance (house mouse, Table 2). Fragmented forest and intact forest had significant decreases in total abundance and Peromyscus spp. abundance from 1999 to 2000 (Table 2). The number of northern short-tailed shrew captures dropped from 35 in 1999 to 2 in 2000 (Table 1) with a significant decrease in intact forest (Table 2). Woodland jumping mice captures increased in both forested treatments (Table 1) from 1999 to 2000 although sample size was too small for analysis.

\section{Demographics of Sherman-trapped Peromyscus}

For Peromyscus spp., abundance varied among some treatments by sex and age. In 1999, adult males were more abundant in grassland than in fragmented or intact forest (Table 4); adult females were more abundant in grasslands than in intact forest. In 2000, for adult males, adult females, and juvenile females, the grassland and shrub/pole treatments were similar, but had 
significantly greater abundances than fragmented forest and intact forest, which were similar to each other. Juvenile males were more abundant in grasslands than in either forest treatment; their abundance in shrub/pole was greater than in fragmented forest. The adult/juvenile ratio was $<1$ in all treatments in 1999 and $>1$ in all treatments except intact forest in 2000 (Table 4). In each year, the intact forest treatment had the lowest adult/juvenile ratio (i.e., there were more juveniles per adult).

In 1999, a significantly greater proportion of male and female Peromyscus spp. was in reproductive condition in the grasslands than in either of the forest treatments (Table 5). In 2000, only females had significant differences among the 4 treatments sampled: a lower percentage of individuals captured were in reproductive condition in the intact forest than in the other 3 treatments.

Reproductive condition differed between the 2 years of the study in some treatments. In the grassland treatment, no between year differences were found for males or females (Table 5). In the fragmented forest treatment, a higher proportion of both males and females were in reproductive condition in 2000. In the intact forest, differences between the years were found in males, but not in females. In all cases of between year differences, the percentage of reproductive individuals was greater in 2000 than in 1999.

\section{Time since reclamation Analysis}

Based on Sherman trapping data in grassland and shrub/pole treatments, species richness was not significantly correlated to the number of years since reclamation (Fig. 1; Pearson product-moment correlation coefficient $=-0.17, P=0.2564)$. Years since reclamation was significantly correlated with total small mammal abundance (Pearson coefficient $=0.43, P=$ 0.0035 ) and Peromyscus abundance (Pearson coefficient $=0.52, P=0.0003$ ) with abundance 
increasing with age of sites. For array data, years since reclamation was not significantly correlated with richness (Fig. 2; Pearson coefficient $=-0.06, P=0.6265$ ), total abundance (Pearson coefficient $=-0.08, P=0.5045)$, or Peromyscus abundance $($ Pearson coefficient $=$ $-0.18, P=0.1206)$.

\section{Habitat Data}

Slope and elevation did not differ significantly among treatments at Sherman (Table 6) or drift fence array (Table 7) sites. Most other habitat variables had significant differences among treatments. Grassland and shrub/pole treatments were similar to each other for most variables, and they generally differed from fragmented and intact forest treatments, which also were similar to each other. Canopy height, canopy cover, and stem density categories above 8 cm DBH were generally greater in the 2 forest treatments than in the reclaimed treatments (canopy height and canopy cover were not measured in grasslands). Of the ground cover variables, green had a higher percentage and leaf litter had a lower percentage in the reclaimed treatments as compared to the forest treatments.

In multiple regression analysis incorporating shrub/pole, fragmented forest, and intact forest treatments, species richness was related to 3 variables based on Sherman trapping data and 4 variables based array trapping data (Table 8). Relations were weak as no single variable contributed a partial $R^{2}>0.10$. Several variables were significantly related to total small mammal abundance and Peromyscus abundance based on Sherman trapping. Of these, canopy cover from 0.5-3 m was negatively related, and contributed the most to each model, with partial $R^{2}$ values of 0.21 and 0.31 for Peromyscus abundance and total abundance, respectively. Based on drift fence data, no variable contributed a partial $R^{2}>0.08$ for total abundance, Peromyscus abundance, woodland vole abundance, or masked shrew abundance. 
Logistic regression analysis of Sherman trapping data for these 3 treatments found that northern short-tailed shrews were more likely to occur where the percentage of bare ground was greater. Based on array data, short-tailed shrews were more likely to occur where moss groundcover was lower, canopy cover from 3-6 $\mathrm{m}$ in height was greater, and when precipitation was greater (Table 9). Based on Sherman trapping, woodland jumping mice were more likely to be captured when the percentage of the moon illuminated was lower, and where the percentage of water as a groundcover and canopy cover from $0.5-3 \mathrm{~m}$ in height were higher. The model developed from array data for jumping mice was a better fit (Hosmer-Lemeshow Goodness-ofFit $\left.\mathrm{X}^{2}=4.26, P=0.7492\right)$; they were more likely to occur where stem density $>38 \mathrm{~cm}$ DBH was greater and stem density $<8 \mathrm{~cm}$ DBH was lower. Eastern chipmunk presence was related to 4 variables; however, the Hosmer-Lemeshow Goodness-of-Fit test suggested that the model was not a good fit (Cody and Smith 1997). Pygmy shrews were more likely to occur where canopy cover from 0.5-3 $\mathrm{m}$ was greater, and smoky shrews were more likely to occur when temperature was higher.

Multiple linear regressions were also performed using only fragmented and intact forest treatments (Table 8). Three variables were related to species richness based on Sherman data, and 4 variables were related based on array data. Low temperature (partial $R^{2}$ value of 0.11 ), negatively related, and percentage of the moon illuminated (partial $R^{2}$ value of 0.15 ), positively related, were the greatest contributors to Sherman and array models, respectively. Based on Sherman data, precipitation was the largest contributor to total abundance and to Peromyscus abundance; it had a negative relation to each and partial $R^{2}$ values of 0.20 and 0.16 , respectively. Based on array data, percentage of the moon illuminated was the largest contributor to total abundance; it was positively related with an $R^{2}$ value of 0.14 . Percent canopy cover from $0.5-3$ 
m was negatively related to Peromyscus abundance; it was the largest contributor of 3 variables with a partial $R^{2}$ value of 0.17 . No variable contributed a partial $R^{2}>0.10$ to woodland vole abundance, while elevation, positively related, was the most significant contributor to masked shrew abundance with a partial $R^{2}$ value of 0.11 .

Logistic regression was performed using data only from fragmented and intact forest treatments for 3 species based on Sherman data and 4 species based on array data (Table 9). For short-tailed shrews, no variables were significant based on Sherman data. Results from array data suggested that short-tailed shrews were more likely to be present where the percentage of canopy cover $>12 \mathrm{~m}$ was lower and when the percentage of the moon illuminated and precipitation were greater and when light index was lower. For woodland jumping mice, percentage of the moon illuminated and canopy height had negative relations with presence based on Sherman data, while the percentage of canopy cover $>12 \mathrm{~m}$ in height, had a negative relation based on array data. Based on Sherman data, eastern chipmunks were more likely to be present where percent bare ground and density of stems $>8-38 \mathrm{~cm} \mathrm{DBH}$ were greater and percent moss and water were lower. Based on array data, pygmy shrews were more likely to be present where water as a groundcover was greater, while smoky shrews were more likely to be present when temperatures were warmer.

Grasslands were analyzed separately from the other treatments. Distance to edge was negatively related to species richness based on multiple regression of Sherman and array data, with partial $R^{2}$ values of 0.12 and 0.16 , respectively (Table 8 ); richness was generally greater closer to edges. Three variables were predictors of total abundance, with the percentage of green groundcover being the strongest with a partial $R^{2}$ of 0.37 . In general, total abundance was higher at sites with more green groundcover. Based on array data, total abundance was negatively 
related to precipitation and distance to edge, with partial $R^{2}$ values of 0.15 and 0.13 , respectively. For Peromyscus spp. abundance based on Sherman data, bare ground had a strong negative relation, with a partial $R^{2}$ of 0.45 . Two variables were negatively related to Peromyscus abundance based on array data, but neither contributed an $R^{2}$ value $>0.08$. Southern bog lemming abundance was negatively related to aspect based on array data, with a partial $R^{2}$ value of 0.13 . Masked shrew abundance was negatively related to the percentage of the moon illuminated, with a partial $R^{2}$ value of 0.14

In logistic regression based on Sherman data, house mice were more likely to be present closer to edges and where there was more bare ground. Based on array data, smoky shrews were more likely to be present where transformed aspect was lower, while no variables were significant to meadow vole and pygmy shrew presence.

\section{DISCUSSION}

The methods used in this study specifically targeted small mammals of the muridae (mice, voles, and rats), soricidae (shrews), and dipodidae (jumping mice) families (Szaro et. al 1988, Blackburn and Andrews 1992). In addition, I captured one member of the sciuridae family (squirrels), the eastern chipmunk, regularly enough to assess its abundance and distribution on the mined landscape. Consequently, the conclusions drawn in this discussion are limited to these species, and do not include other groups of animals that are sometimes considered small mammals, such as bats (Order Chiroptera), moles (Family Talpidae), rabbits (Order Lagomorpha) and small weasels (Family Mustelidae). It is important to note that the abundance and distribution of these species may not follow patterns of targeted species yet are equally important components of the small mammal communities. 
Peromyscus spp. made up $87 \%$ of Sherman captures during the study. Small mammal studies using live traps or snap traps on mined landscapes have often reported similar findings, with Peromyscus spp. accounting for 74-87\% of captures (Kirkland 1976, Sly 1976, Voight and Glenn-Lewin 1979). Several studies on reclaimed mines were designed to target Peromyscus spp. (Verts 1957, Hansen and Warnock 1978, Linzey 1989), presumably because it is difficult to get large enough sample sizes for analysis of less common species.

Pitfall traps and funnel traps associated with drift fence arrays were effective at capturing many species that were rare or absent from Sherman traps in adequate numbers for statistical analysis. For example, small shrews that were not heavy enough to spring Sherman traps (Szaro et. al 1988, Blackburn and Andrews 1992) and microtine rodents that may not have been attracted to the bait were virtually absent from Sherman traps but were common in drift fence traps. Conversely, Sherman trapping was effective at capturing larger species that could not fit into funnel traps or were too agile to fall into pitfall traps, such as eastern chipmunks and Allegheny woodrats. Combining these 2 methods maximized the number of species captured, providing a more complete picture of the small mammal community (Table 10). Based on WV GAP analysis data, personal communication by M. E. Hight (mammalogist, Marshall University), and Whitaker and Hamilton (1998), I captured all species of small mammals expected to occur in our study area with 2 possible exceptions. Southern red-backed voles (Clethrionomys gapperi) were not captured, but they are associated with mesic high-elevation forests in the Appalachians (Wharton and White 1967) and my trapping sites were in lower elevation forests. I also did not capture golden mice (Ochrotomys nuttalli), but sources vary as to whether they range into our study areas (personal communication M. E. Hight 2000). 


\section{Peromyscus Species Abundance}

In 2000 Sherman trap data, Peromyscus abundance was higher in the 2 reclaimed treatments than in the 2 forest treatments. Drift fence array data showed a similar trend, with abundance lowest in intact forest. Most previous studies have also found that Peromyscus spp. benefit from disturbances that create early-successional habitats such as mining (Verts 1957, Mumford and Bramble 1973, DeCapita and Bookout 1975, Kirkland 1976, Hansen and Warnock 1978) and forest clearcutting (Kirkland 1977, Buckner and Shure 1985). Peromyscus abundance did not follow this trend in 1999 Sherman trapping when all treatments were statistically similar. This may have been a result of increased mortality in grasslands due to hotter than normal weather (Fig. 2) combined with an extreme summer drought (Fig. 3), or perhaps the weather forced the generalist Peromyscus spp. to leave the grasslands for the more moist and moderate forests on adjacent lands (see below).

Differences in Peromyscus abundance between the 2 years from Sherman trap data may be explained by changes in weather patterns between the years (Gentry et al. 1966, Vickery and Bider 1981, Vickery and Rivest 1992). From May-August of 1999 and 2000, 29.2 and $47.0 \mathrm{~cm}$ of rain, respectively, were recorded in Charleston (Fig. 3), the nearest NOAA weather station to the study sites. The norm for this period is $40.8 \mathrm{~cm}$, making summer 1999 a period of extreme drought. Average daily high temperatures for 1999 and 2000 were $29.1 \mathrm{C}^{\circ}$ and $26.9 \mathrm{C}^{\circ}$, respectively, during those same months (Fig. 2), with a normal temperature of $27.9 \mathrm{C}^{\circ}$ for the 4month period. Peromyscus abundance was lower in grasslands in 1999 than 2000, while it was higher in the fragmented and intact forest treatments in 1999 than 2000 (Table 2). Because Peromyscus are habitat generalists (Whitaker and Hamilton 1998), it is possible that they select home ranges based on the microclimate and abundance of forage and prey items. The drought in 
1999 combined with hotter than normal temperatures may have made the grassland a difficult area to inhabit, causing individuals to leave the open grasslands for the relief of the adjacent forests. These conditions may also have led to a decrease in survivorship in grasslands. Alternatively, the forested areas in 2000 may have been uncomfortably cool and damp causing individuals to move to warmer, more open areas or individuals experienced lower survival in forested habitats. Overwinter survival could also have contributed to the greater overall abundance in 2000 than in 1999. There was a period of colder than normal weather in the region from mid-February to late April in 1999, which could result in greater mortality or lower reproduction; in 2000, temperatures were warmer than normal during this period. This may be a critical period as it is the start of the breeding season (Whitaker and Hamilton 1998). In the forested treatments, mast crops may have been a factor contributing to the greater number of mice in 1999 than in 2000. Hard mast is an important food source for the winter survival of Peromyscus spp. (Wolff 1996, McCracken et al. 1999). The hard mast crop in the fall of 1998 was significantly above average in West Virginia (Pack 1998), while the fall of 1999 had a much lower than normal hard mast production throughout West Virginia as an effect of the summer drought (Pack 1999).

As succession proceeds following mining, Peromyscus abundance generally decreases as demonstrated on reclaimed mine lands 4-22 years in age by Verts (1957), 5-50 years in age by Wetzel (1958), and 5-28 years in age by Sly (1967). My results did not show this for early stages of succession, however, as abundance estimates were similar in the shrub/pole and grassland treatments for both sampling methods. Grassland MTMVF sites ranged from 7-21, and shrub/pole sites ranged from 18-28 years since reclamation. Sites in the 2 treatments overlapped in age because they were categorized based on structure, and areas planted with 
woody species during reclamation reached shrub/pole stage more quickly. Almost all habitat variables common to the grassland and shrub/pole treatments were similar between them (Tables 6 and 7), indicating that these treatments may have provided similar habitat conditions for small mammals. Grasslands lacked trees $>8 \mathrm{~cm} \mathrm{DBH}$ at Sherman and drift fence array sites, but this may not be as important to small mammals as aspect, litter depth, ground cover, and low shrub cover which can contribute to microsite conditions, as demonstrated by regression results. Peromyscus spp. abundance did decrease, as expected, once succession reached forest conditions.

Succesional changes in small mammal communities on MTMVF landscapes also were examined by plotting and correlating richness, total small mammal abundance, and Peromyscus abundance against time since reclamation (Fig. 1). Richness did not change significantly with age of reclaimed sites. This result concurred with several other studies that did not find a relation between richness and time since reclamation (Wetzel 1958, Sly 1976, Urbanek and Klimstra 1986). Small mammal richness may remain fairly constant over time because early-successional species that are lost are often replaced by other species, so there is no net change. Total small mammal abundance and Peromyscus abundance showed a significant increase with time since reclamation. In contrast, most other studies found higher abundances at more recently reclaimed sites (Verts 1957, Wetzel 1958, Sly 1976, Hansen and Warnock 1978, Urbanek and Klimstra 1986). My results may differ from previous studies because management of reclaimed MTMVF sites was different at each mine, a fact that could confound time effects. For example, some sites had been planted with black locust, European black alder, and other tree species while other sites were planted only with grasses and perhaps crown vetch. Successional state, therefore, was not necessarily related to time since reclamation on the 3 mines. Another possible explanation for 
the lower abundance on more recently reclaimed sites in my study is that these sites may have had more bare ground, which had a strong negative relation to Peromyscus abundance.

\section{Demographics of Sherman-trapped Peromyscus}

To provide further insight into differences among treatments, demographic parameters of Sherman-trapped mammals were examined because abundance is not necessarily a reliable indicator of habitat quality for a given species (Van Horne 1983). Peromyscus spp., as habitat generalists, can exist in a variety of habitats (Whitaker and Hamilton 1998) but demographic data may suggest that one habitat is of better quality than another (Adler et al. 1984, Adler and Wilson 1987). Juveniles and subordinate individuals, for example, may be forced into an area where there is low survivorship and reproduction due to lack of food and cover-a population sink (Lidicker 1975, Pulliam 1988, 1996). Several studies have suggested that reclaimed lands may act as sinks for Peromyscus and that adjacent unmined lands may provide superior breeding and foraging habitat (De Capita and Bookout 1975, Voight and Glenn-Lewin 1979, Linzey 1989). To test this, I compared the proportion of individuals that were in breeding condition. The results followed the abundance trends with a greater proportion of adults in breeding condition in the early-successional habitats, suggesting that reclaimed areas were not acting as population sinks on our study sites, but were actually productive breeding sites. I also compared sex and age group abundance among treatments because adult Peromyscus, unlike the subordinate juveniles, compete for the best available territory; therefore, their presence may be a better indicator of habitat quality than juvenile abundance (Lidicker 1975, Van Horne 1982, 1983, Doyle 1990). In 1999, abundance of adult males was higher in the grassland treatment than in the 2 forest treatments. These differences suggested that reclaimed areas provided superior habitat to forests. Trends in adult/juvenile ratios did not necessarily concur with this 
conclusion, however. Adult/juvenile ratios were used measure of offspring production which is another means of assessing habitat quality (Van Horne 1983). In both 1999 and 2000, ratios were lowest in intact forest, indicating that more juveniles were captured per adult in this treatment. This may suggest that populations in intact forest are more productive than in other treatments, or, alternatively, that the higher population within the reclaimed areas resulted in a greater number of non-breeding adults. Another possibility is that juveniles were not more abundant in intact forests because they were born there, but because they were driven into a marginal habitat by dominant animals in adjacent treatments.

In summary, despite the fact that adult/juvenile ratios were possibly in conflict, the combination of demographic and abundance data supports the idea that reclaimed treatments provided superior Peromyscus habitat. Reclaimed areas may provide a greater biomass of herbaceous forage and seeding plants, such as grasses and forbs. In addition, the structure provided by these plants may be important cover for nesting and predator avoidance.

\section{Other Species}

The presence of house mice in grasslands but not in other treatments was consistent with published literature. In addition to human dwellings and buildings, house mice have been found in grassy fields and croplands but almost never in forests (Kaufman and Kaufman 1990, Whitaker and Hamilton 1998). House mice were captured on reclaimed mines in several other studies (Yeager 1942, Verts 1959, Mumford and Bramble 1973).

Woodland jumping mice were captured primarily in fragmented forest by both Sherman traps and drift fence arrays. Logistic regression of Sherman trap data identified water and canopy cover from $0.5-3 \mathrm{~m}$ as predictors of the presence of woodland jumping mice (Table 8). This was consistent with Whitaker and Wrigley's (1972) description of them as a forest dweller often 
found near streams and where there is significant understory. Their greater abundance in fragmented forest than in intact forest is likely related to the significantly higher percentage of water as a ground cover in fragmented forest (Table 6). In addition, fragments may have provided more understory vegetation than intact forests due to the effect of sunlight entering the forest at edges.

Three microtine rodents were captured by both trapping methods, but more commonly by drift fence arrays. Bog lemmings were more abundant in reclaimed areas and were absent from intact forest. This was consistent with other accounts; Kirkland (1977) captured bog lemmings in clearcuts but not in either deciduous or coniferous forests and Connor (1959) found them to be reliant on sedges and grasses for a food source. In grasslands, bog lemming abundance was negatively related to transformed aspect. This suggests that they were more abundant at drier sites because transformed values are on a scale of 0 (southwestern exposure, xeric conditions) to 2 (northeastern exposure, mesic conditions) (Beers et al. 1966). However, bog lemmings were not captured in 1999 when conditions were very dry, while they were captured in 2000 and 2001 when conditions were very wet. Whitaker and Hamilton (1998) describe bog lemmings as present in a variety of habitats, including dry fields, but rarely occupying bogs. Woodland voles were less abundant in grasslands than in intact forests. In a laboratory study, woodland voles chose sites with cooler, more organic soils over warmer, rocky soils (Rhodes and Richmond 1985). This may explain their lower numbers in the grassland treatment, where soils were likely to be too warm and rocky for them. Meadow voles did not differ in abundance among treatments. This may have been a function of having a small sample size and the broad habitat requirements of this species (Whitaker and Hamilton 1998). 
Northern short-tailed shrews were more abundant in fragmented forest than other treatments based on drift fence arrays, although Sherman abundance was higher in intact forest in 1999. Greater percentage of bare ground was positively related to short-tailed shrew presence from Sherman trapping sites, while moss groundcover was a negative predictor and canopy cover from 3-6 $\mathrm{m}$ and precipitation were identified as positively related based on drift fence array sites. Bare ground was not expected to predict short-tailed shrew presence considering they often hunt for invertebrates in leaf litter (Getz 1961). However, this result may be a factor of reclaimed sites where they were less common having lower percentages of bare ground and more grass and herbaceous cover. Canopy cover from 3-6 m may be important for providing shade and a moist, cool microclimate and precipitation events provide moisture and may affect abundance of insect prey items. Northern short-tailed shrew abundance based on Sherman trapping dropped precipitously from 1999 to 2000 . Drift fence array trapping also suggested that abundance was low in 2000 as only 21 short-tailed shrews were caught that year compared to 108 in 2001. Decreased reproduction or increased mortality during the summer 1999 drought may have contributed to this trend. Short-tailed shrews have a high rate of evaporation from the skin (George et al. 1986) and are known to be unable to tolerate hot and dry conditions. Other studies also have noted wide yearly fluctuations in the abundance of this species, but the reason for this is not well understood (Lindeborg 1941, Fowle and Edwards 1955, Getz 1984, 1989).

Three shrew species of the genus Sorex were captured by drift fence arrays. Masked shrews were more abundant in reclaimed areas, a difference that was not expected. This species is a habitat generalist whose major requirement is that a habitat is moist (Moore 1949, Whitaker and Hamilton 1998). Smoky shrew abundance did not differ among treatments. They typically select for damp woods (Caldwell and Bryan 1982), so were not expected to occur in grasslands. 
Transformed aspect was negatively related to smoky shrew presence in grasslands, suggesting that they were more likely to inhabit mesic grassland sites. Pygmy shrews, typically found in upland woods (Whitaker and Hamilton 1998), did not differ in abundance among treatments. The rainfall during spring - summer 2000 and 2001 probably allowed all 3 shrew species of to exist in grasslands that would otherwise have been too hot and dry.

Eastern chipmunks were captured almost exclusively in the 2 forest treatments. This result was expected as they are a forest-dwelling animal (Whitaker and Hamilton 1998). The fact that chipmunks were found much more frequently in intact than fragmented forests was not necessarily expected as chipmunks are often associated with forest edge (Pyare et al. 1993). Nupp and Swihart (1998) did find, however, that survival rates decreased for Eastern chipmunks in small woodlots, possibly due to increased predation. Mahan and Yahner (1999) also reported that chipmunks using forest corridors, which were narrow strips of woods resembling our fragmented forest treatment, spent a greater proportion of their time pausing and looking for predators than in intact forests.

The Allegheny woodrat was an unexpected capture in shrub/pole areas. The sites were characterized by the presence of a reclaimed drainage channel filled with large rip-rap boulders shaded by a few trees that lined the channel. These areas differ substantially from their typical habitat of rock outcrops in forested areas (Poole 1940), but rock structure in channels may provide ample interstitial space for nest building and predator avoidance, while the vegetation surrounding channels provides a variety of food sources. The use of constructed channels on a mined landscape by woodrats is especially interesting because the species has declined drastically in parts of its range and is thought to be affected by habitat fragmentation (Balcom and Yahner 1996). 


\section{Species Richness and Community Composition}

Species richness estimates based on Sherman trapping did not differ significantly among treatments in either year and rarely exceeded 2 species per transect. In the shrub/pole and the 2 forest treatments, richness was negatively related to 2 environmental variables, temperature and precipitation, suggesting that fewer species were active when it was rainy or warm. This may have been a result of animals seeking shelter during significant rain events, or foraging in upland areas to avoid the possibility of flooding in riparian areas where Sherman traps were placed.

Richness estimates based on drift fence arrays were generally greater than estimates based on Sherman trapping, partly because pitfall and funnel traps can continue capturing animals after the first capture, while Sherman traps may become occupied by the same traphappy individuals on each night of trapping. Intact forest had significantly lower richness than other treatments. In regression based on shrub/pole, fragmented forest, and intact forest and based on just fragmented and intact forest, percentage of the moon illuminated was the strongest contributor. The increase in number of species when the moon was brighter was not expected, as other studies have found less small mammal activity when the moon was brighter (Kaufmann and Kaufmann 1982, Travers et al. 1988). This result may be misleading because cloud cover on nights when the moon was bright could have reduced the amount of ambient light.

Overall, 13 species were captured in grasslands, 10 in shrub/pole, 11 in fragmented forest, and 9 in intact forest (Table 10). The greater number of species in grassland treatments reflects the fact that a diversity of habitat types result from the creation of large openings. For example, the forest edge is created, and open lands themselves are diverse because they are made up of habitat patches in different stages of succession and varying levels of groundcover. In grasslands, species richness was significantly related to distance to edge, also suggesting that 
habitat heterogeneity is important in maintaining species richness. Intact forest habitat may contain fewer small mammal species because it is more homogeneous, lacking habitat diversity.

One of the effects of MTMVF is a change in the species composition in the small mammal community. Some species are lost and some gained as large expanses of intact forest are converted into grassland or shrub/pole. House mice, for example, were only captured in grasslands. They are a non-native, invasive species, so their presence, and potential competition with native Peromyscus spp. is not necessarily a positive. Another species captured primarily in reclaimed areas was the southern bog lemming, listed as rare by the West Virginia Wildlife \& Natural Heritage Program (2000). Linzey (1983) described bog lemming habitat in the southern Appalachians as meadows, dry broomsedge, fields, pastures, grassy openings in forest, power line right-of-ways, and clearcuts. Similarly, meadow voles are described as a species with a preference for open habitats (Whitaker and Hamilton 1998), although I did not detect an abundance difference among treatments. Mining, therefore, expands the habitat of boglemmings and meadow voles. Eastern chipmunks and woodland jumping mice appear to be negatively affected by mining as they were absent (with a few exceptions) from reclaimed areas. Their typical habitat is forest (Whitaker and Hamilton 1998) so they may be less common than on the pre-mined landscape. The effects of fragmentation on these species is unclear, as chipmunks were significantly more abundant in intact forest and jumping mice were more abundant in fragmented forest. Other research on chipmunks did not necessarily agree with this result (Pyare et al. 1993), while studies comparing abundance of woodland jumping mice among different sized forest patches were not found in the literature. 


\section{Summary and Conclusions}

Peromyscus spp. were the most abundant small mammals on the reclaimed MTMVF landscape. They are known to be a colonizer of early-successional habitats, so their abundance was not surprising. Demographic parameters of live-trapped Peromyscus were compared among treatments because abundance alone does not always imply superior habitat (Van Horne 1982, 1983). Demographic information was generally in concurrence with abundance results, suggesting that reclaimed areas provided better habitat for Peromyscus spp. Adult/juvenile ratios, however, suggested that intact forests may be more productive breeding areas than reclaimed lands.

Species richness estimates based on drift fence arrays were lower in intact forest than in grasslands, shrub/pole, and fragmented forest treatments. The post-mining landscape may be more species rich because the disturbance creates a mixture of habitats, such as forest edge and open lands in varying stages of succession. An intact forest, in contrast, is more homogeneous. Grassland interiors also may be more homogenous, as suggested by the negative relation between species richness and distance to habitat edge in the grassland treatment. Thus, a landscape containing forest and several small grassland openings may have greater species richness and evenness than a landscape containing a single, large grassland surrounded by forest.

Species composition also differed among treatments (Table 3 and Table 10). With the conversion of a relatively intact forest landscape to large grassland and shrub/pole habitats with forest patches, some species are lost and some are gained. In addition to Peromyscus, bog lemmings, masked shrews, and house mice apparently have benefited from the created grasslands. However, one species that was gained in grasslands is a non-native species (house mouse). Species that may be reduced in abundance and/or lost from the small mammal 
community in the conversion to open habitats include eastern chipmunks, woodland jumping mice, woodland voles, and northern short-tailed shrews.

In addition, weather patterns may affect small mammal abundance and community composition in grasslands more than in the forests because fluctuations in microclimate are more severe in open habitats. For example, three shrew species that generally prefer woods and moist habitats were captured more frequently than expected in grasslands during the wet summers of 2000 and 2001. Shrew species are sensitive to moisture loss (Getz 1961, George et al. 1986) and are not as likely to be found in grasslands during a hot, dry summer. 
Table 1. Average mammalian species richness (\# species/transect), relative abundance (mammals/100 trap nights), and standard errors (SE) in grassland, shrub/pole, fragmented forest, and intact forest treatments on MTMVF landscapes in southern West Virginia for 1999 and 2000.

\begin{tabular}{|c|c|c|c|c|c|c|c|c|c|c|c|c|c|c|}
\hline & \multicolumn{12}{|c|}{ Treatment } & \multirow{2}{*}{\multicolumn{2}{|c|}{$\begin{array}{l}\text { ANOVA } \\
\text { Results }^{\mathrm{a}}\end{array}$}} \\
\hline & \multicolumn{3}{|c|}{ Grassland } & \multicolumn{3}{|c|}{ Shrub/Pole } & \multicolumn{3}{|c|}{ Forest Fragment } & \multicolumn{3}{|c|}{ Intact Forest } & & \\
\hline & Mean & SE & Count $^{\mathrm{b}}$ & Mean & SE & Count & Mean & $\mathrm{SE}$ & Count & Mean & SE & Count & $\mathrm{F}$ & $P$ \\
\hline \multicolumn{15}{|l|}{ Species Richness } \\
\hline Sherman 1999 & $1.69 \mathrm{~A}$ & 0.18 & 5 & - & - & - & $1.81 \mathrm{~A}$ & 0.25 & 6 & $2.25 \mathrm{~A}$ & 0.19 & 4 & 2.28 & 0.1164 \\
\hline Sherman 2000 & $1.40 \mathrm{~A}$ & 0.13 & 6 & $1.50 \mathrm{~A}$ & 0.12 & 4 & $1.40 \mathrm{~A}$ & 0.15 & 4 & $1.40 \mathrm{~A}$ & 0.13 & 3 & 0.17 & 0.9138 \\
\hline Drift Fence Array & $2.85 \mathrm{~A}^{\mathrm{c}}$ & 0.25 & 10 & $2.74 \mathrm{~A}$ & 0.22 & 9 & $2.82 \mathrm{~A}$ & 0.28 & 10 & $1.90 \mathrm{~B}$ & 0.25 & 9 & 5.58 & 0.0014 \\
\hline \multicolumn{15}{|l|}{ Relative Abundance } \\
\hline \multicolumn{15}{|l|}{ Total } \\
\hline Sherman 1999 & $15.68 \mathrm{~A}$ & 1.43 & 177 & - & - & - & $12.59 \mathrm{~A}$ & 0.94 & 138 & $14.48 \mathrm{~A}$ & 1.87 & 160 & 1.57 & 0.2214 \\
\hline Sherman 2000 & $21.79 \mathrm{~A}$ & 2.38 & 267 & $20.20 \mathrm{~A}$ & 2.12 & 154 & $7.52 \mathrm{~B}$ & 1.07 & 106 & $7.92 \mathrm{~B}$ & 1.83 & 94 & 28.19 & $<0.0001$ \\
\hline Drift Fence Array & $14.47 \mathrm{~A}$ & 1.70 & 338 & $12.94 \mathrm{~A}$ & 1.56 & 306 & $12.10 \mathrm{~A}$ & 2.39 & 272 & $7.36 \mathrm{~B}$ & 1.48 & 171 & 4.02 & 0.0095 \\
\hline \multicolumn{15}{|l|}{ Peromyscus species } \\
\hline Sherman 1999 & $13.50 \mathrm{~A}$ & 1.08 & 152 & - & - & - & $10.79 \mathrm{~A}$ & 0.69 & 115 & $11.33 \mathrm{~A}$ & 1.59 & 126 & 2.48 & 0.0977 \\
\hline Sherman 2000 & $20.40 \mathrm{~A}$ & 2.58 & 246 & $18.89 \mathrm{~A}$ & 2.52 & 143 & $6.02 \mathrm{~B}$ & 0.78 & 89 & $6.63 \mathrm{~B}$ & 1.65 & 178 & 33.76 & $<0.0001$ \\
\hline Drift Fence Array & $5.52 \mathrm{~A}$ & 0.83 & 137 & $4.71 \mathrm{AB}$ & 0.89 & 109 & $4.15 \mathrm{AB}$ & 1.02 & 92 & $2.52 \mathrm{~B}$ & 0.89 & 60 & 2.23 & 0.0896 \\
\hline \multicolumn{15}{|l|}{ House mouse } \\
\hline Sherman 1999 & $1.91 \mathrm{~A}$ & 0.83 & 21 & - & - & - & $0.00 \mathrm{~B}$ & 0.00 & 0 & $0.00 \mathrm{~B}$ & 0.00 & 0 & 6.09 & 0.0053 \\
\hline Sherman 2000 & $0.97 \mathrm{~A}$ & 0.59 & 15 & $0.00 \mathrm{~B}$ & 0.00 & 0 & $0.00 \mathrm{~B}$ & 0.00 & 0 & $0.00 \mathrm{~B}$ & 0.00 & 0 & 3.82 & 0.0148 \\
\hline Drift Fence Array & 0.06 & 0.04 & 2 & 0.00 & 0.00 & 0 & 0.00 & 0.00 & 0 & 0.00 & 0.00 & 0 & & \\
\hline \multicolumn{15}{|c|}{ Woodland jumping mouse } \\
\hline Sherman 1999 & $0.00 \mathrm{~A}$ & 0.00 & 0 & - & - & & $0.65 \mathrm{~A}$ & 0.39 & 7 & $0.00 \mathrm{~A}$ & 0.00 & 0 & 2.52 & 0.0943 \\
\hline Sherman 2000 & $0.00 \mathrm{~A}$ & 0.00 & 0 & $0.00 \mathrm{~A}$ & 0.00 & 0 & $0.95 \mathrm{~A}$ & 0.58 & 14 & $0.46 \mathrm{~A}$ & 0.27 & 5 & 2.96 & 0.0405 \\
\hline Drift Fence Array & $0.03 \mathrm{~B}$ & 0.03 & 1 & $0.09 \mathrm{~B}$ & 0.06 & 2 & $0.60 \mathrm{~A}$ & 0.16 & 15 & $0.10 \mathrm{~B}$ & 0.10 & 3 & 6.28 & 0.0006 \\
\hline
\end{tabular}




\begin{tabular}{|c|c|c|c|c|c|c|c|c|c|c|c|c|c|c|}
\hline & \multicolumn{12}{|c|}{ Treatment } & \multirow{2}{*}{\multicolumn{2}{|c|}{$\begin{array}{l}\text { ANOVA } \\
\text { Results }^{\mathrm{a}}\end{array}$}} \\
\hline & \multicolumn{3}{|c|}{ Grassland } & \multicolumn{3}{|c|}{ Shrub/Pole } & \multicolumn{3}{|c|}{ Forest Fragment } & \multicolumn{3}{|c|}{ Intact Forest } & & \\
\hline & Mean & SE & Count $^{b}$ & Mean & SE & Count & Mean & SE & Count & Mean & $\mathrm{SE}$ & Count & $\mathrm{F}$ & $P$ \\
\hline \multicolumn{15}{|l|}{ Meadow vole } \\
\hline Sherman 1999 & 0.08 & 0.08 & 1 & - & - & - & 0.00 & 0.00 & 0 & 0.00 & 0.00 & 0 & & \\
\hline Sherman 2000 & 0.00 & 0.00 & 0 & 0.25 & 0.17 & 2 & 0.00 & 0.00 & 0 & 0.00 & 0.00 & 0 & & \\
\hline Drift Fence Array & $0.28 \mathrm{~A}$ & 0.11 & 7 & $0.23 \mathrm{~A}$ & 0.11 & 4 & $0.34 \mathrm{~A}$ & 0.13 & 9 & $0.09 \mathrm{~A}$ & 0.06 & 2 & 1.16 & 0.3304 \\
\hline \multicolumn{15}{|l|}{ Woodland vole } \\
\hline Sherman 1999 & 0.00 & 0.00 & 0 & - & - & - & 0.00 & 0.00 & 0 & 0.09 & 0.09 & 1 & & \\
\hline Sherman 2000 & 0.00 & 0.00 & 0 & 0.00 & 0.00 & 0 & 0.00 & 0.00 & 0 & 0.00 & 0.00 & 0 & & \\
\hline Drift Fence Array & $0.14 \mathrm{~B}$ & 0.08 & 3 & $0.48 \mathrm{AB}$ & 0.15 & 11 & $0.49 \mathrm{AB}$ & 0.15 & 13 & $0.83 \mathrm{~A}$ & 0.33 & 18 & 2.13 & 0.1006 \\
\hline \multicolumn{15}{|c|}{ Southern bog lemming } \\
\hline Sherman 1999 & 0.00 & 0.00 & 0 & - & - & - & 0.00 & 0.00 & 0 & 0.00 & 0.00 & 0 & & \\
\hline Sherman 2000 & 0.09 & 0.09 & 1 & 0.10 & 0.10 & 1 & 0.00 & 0.00 & 0 & 0.00 & 0.00 & 0 & & \\
\hline Drift Fence Array & $1.90 \mathrm{~A}$ & 0.47 & 48 & $1.42 \mathrm{~A}$ & 0.37 & 32 & $0.25 \mathrm{~B}$ & 0.13 & 6 & $0.00 \mathrm{~B}$ & 0.00 & 0 & 8.64 & $<0.0001$ \\
\hline \multicolumn{15}{|l|}{ Eastern chipmunk } \\
\hline Sherman 1999 & $0.00 \mathrm{~B}$ & 0.00 & 0 & - & - & - & $0.08 \mathrm{~B}$ & 0.08 & 1 & $0.89 \mathrm{~A}$ & 0.31 & 10 & 9.41 & 0.0005 \\
\hline Sherman 2000 & $0.07 \mathrm{~B}$ & 0.07 & 1 & $0.00 \mathrm{~B}$ & 0.00 & 0 & $0.06 \mathrm{~B}$ & 0.06 & 1 & $0.83 \mathrm{~A}$ & 0.35 & 11 & 3.87 & 0.0141 \\
\hline Drift Fence Array & 0.00 & 0.00 & 0 & 0.00 & 0.00 & 0 & 0.00 & 0.00 & 0 & 0.07 & 0.07 & 2 & & \\
\hline \multicolumn{15}{|l|}{ Allegheny woodrat } \\
\hline Sherman 1999 & 0.00 & 0.00 & 0 & - & - & - & 0.00 & 0.00 & 0 & 0.00 & 0.00 & 0 & & \\
\hline Sherman 2000 & $0.00 \mathrm{~B}$ & 0.00 & 0 & $1.23 \mathrm{~A}$ & 0.67 & 8 & $0.00 \mathrm{~B}$ & 0.00 & 0 & $0.00 \mathrm{~B}$ & 0.00 & 0 & 5.92 & 0.0014 \\
\hline Drift Fence Array & 0.00 & 0.00 & 0 & 0.00 & 0.00 & 0 & 0.00 & 0.00 & 0 & 0.00 & 0.00 & 0 & & \\
\hline \multicolumn{15}{|c|}{ Northern short-tailed shrew } \\
\hline Sherman 1999 & $0.21 \mathrm{~B}$ & 0.21 & 2 & - & - & - & $0.92 \mathrm{AB}$ & 0.38 & 10 & $2.07 \mathrm{~A}$ & 0.62 & 23 & 5.1 & 0.0113 \\
\hline Sherman 2000 & 0.00 & 0.00 & 0 & 0.00 & 0.00 & 0 & 0.17 & 0.12 & 2 & 0.00 & 0.00 & 0 & & \\
\hline Drift Fence Array & $0.62 \mathrm{~B}$ & 0.25 & 15 & $0.74 \mathrm{~B}$ & 0.20 & 18 & $3.45 \mathrm{~A}$ & 1.00 & 76 & $0.78 \mathrm{~B}$ & 0.24 & 20 & 15.05 & $<0.0001$ \\
\hline
\end{tabular}




\begin{tabular}{|c|c|c|c|c|c|c|c|c|c|c|c|c|c|c|}
\hline & \multicolumn{12}{|c|}{ Treatment } & \multirow{2}{*}{\multicolumn{2}{|c|}{$\begin{array}{l}\text { ANOVA } \\
\text { Results }^{\mathrm{a}}\end{array}$}} \\
\hline & \multicolumn{3}{|c|}{ Grassland } & \multicolumn{3}{|c|}{ Shrub/Pole } & \multicolumn{3}{|c|}{ Forest Fragment } & \multicolumn{3}{|c|}{ Intact Forest } & & \\
\hline & Mean & SE & Count $^{\mathrm{b}}$ & Mean & SE & Count & Mean & SE & Count & Mean & SE & Count & $\mathrm{F}$ & $P$ \\
\hline \multicolumn{15}{|l|}{ Masked shrew } \\
\hline Sherman 1999 & 0.00 & 0.00 & 0 & - & - & - & 0.08 & 0.08 & 1 & 0.10 & 0.10 & 1 & & \\
\hline Sherman 2000 & 0.00 & 0.00 & 0 & 0.00 & 0.00 & 0 & 0.06 & 0.06 & 0 & 0.00 & 0.00 & 0 & & \\
\hline Drift Fence Array & $3.43 \mathrm{~A}$ & 0.79 & 77 & $3.96 \mathrm{~A}$ & 0.96 & 103 & $1.18 \mathrm{~B}$ & 0.37 & 32 & $1.41 \mathrm{~B}$ & 0.35 & 37 & 5.07 & 0.0026 \\
\hline \multicolumn{15}{|l|}{ Smoky shrew } \\
\hline Sherman 1999 & 0.00 & 0.00 & 0 & - & - & - & 0.00 & 0.00 & 0 & 0.00 & 0.00 & 0 & & \\
\hline Sherman 2000 & 0.00 & 0.00 & 0 & 0.00 & 0.00 & 0 & 0.00 & 0.00 & 0 & 0.00 & 0.00 & 0 & & \\
\hline Drift Fence Array & $0.39 \mathrm{~A}$ & 0.16 & 10 & $0.15 \mathrm{~A}$ & 0.07 & 4.00 & $0.14 \mathrm{~A}$ & 0.07 & 4.00 & $0.30 \mathrm{~A}$ & 0.13 & 9 & 1.10 & 0.3522 \\
\hline \multicolumn{15}{|l|}{ Pygmy shrew } \\
\hline Sherman 1999 & 0.00 & 0.00 & 0 & - & - & - & 0.00 & 0.00 & 0 & 0.00 & 0.00 & 0 & & \\
\hline Sherman 2000 & 0.00 & 0.00 & 0 & 0.00 & 0.00 & 0 & 0.00 & 0.00 & 0 & 0.00 & 0.00 & 0 & & \\
\hline Drift Fence Array & $0.09 \mathrm{~A}$ & 0.06 & 2 & $0.03 \mathrm{~A}$ & 0.03 & 1 & $0.26 \mathrm{~A}$ & 0.09 & 7 & $0.22 \mathrm{~A}$ & 0.10 & 6 & 1.91 & 0.1327 \\
\hline \multicolumn{15}{|l|}{ Virginia opossum } \\
\hline Sherman 1999 & 0.00 & 0.00 & 0 & - & - & - & 0.30 & 0.30 & 4 & 0.00 & 0.00 & 0 & & \\
\hline Sherman 2000 & 0.09 & 0.09 & 1 & 0.00 & 0.00 & 0 & 0.00 & 0.00 & 0 & 0.00 & 0.00 & 0 & & \\
\hline Drift Fence Array & 0.00 & 0.00 & 0 & 0.00 & 0.00 & 0 & 0.03 & 0.03 & 1 & 0.00 & 0.00 & 0 & & \\
\hline \multicolumn{15}{|l|}{ Eastern cottontail } \\
\hline Sherman 1999 & 0.06 & 0.06 & 1 & - & - & - & 0.00 & 0.00 & 0 & 0.00 & 0.00 & 0 & & \\
\hline Sherman 2000 & 0.26 & 0.20 & 3 & 0.00 & 0.00 & 0 & 0.00 & 0.00 & 0 & 0.00 & 0.00 & 0 & & \\
\hline Drift Fence Array & 0.00 & 0.00 & 0 & 0.00 & 0.00 & 0 & 0.00 & 0.00 & 0 & 0.00 & 0.00 & 0 & & \\
\hline
\end{tabular}

\footnotetext{
${ }^{\mathrm{a}} \mathrm{F}$ and $P$ are given where sample size was large enough to perform statistical analysis.

${ }^{\mathrm{b}}$ Refers to the number of species (with regard to richness) or the number of individuals captured (with regard to abundance).

${ }^{\mathrm{c}}$ Means followed by different letters within a row are significantly different (Waller-Duncan k-ratio $t$-test, $P \leq 0.05$ ).
} 
Table 2. Average richness (\# species/transect) and abundance (mammals/100 trap nights) compared between 1999 and 2000 in grassland, shrub/pole, fragmented forest, and intact forest treatments on MTMVF landscapes in southern West Virginia based on Sherman trapping.

\begin{tabular}{|c|c|c|c|c|c|}
\hline & \multicolumn{2}{|c|}{ Year } & \multicolumn{3}{|c|}{ ANOVA Results } \\
\hline & 1999 & 2000 & $\mathrm{~F}$ & $\mathrm{df}$ & $P$ \\
\hline \multicolumn{6}{|l|}{ Species Richness } \\
\hline$\overline{\text { Total }^{\mathrm{a}}}$ & 1.92 & 1.42 & 16.44 & 1 & $<0.01$ \\
\hline Grassland & 1.69 & 1.40 & 0.82 & 1 & 0.37 \\
\hline Fragmented Forest & 1.81 & 1.40 & 2.54 & 1 & 0.12 \\
\hline Intact Forest & 2.25 & 1.40 & 13.82 & 1 & $<0.01$ \\
\hline \multicolumn{6}{|l|}{ Relative Abundance $^{\mathrm{b}}$} \\
\hline Total $^{\mathrm{a}}$ & 14.25 & 13.70 & 0.1 & 1 & 0.75 \\
\hline Grassland & 15.68 & 21.79 & 4.26 & 1 & 0.046 \\
\hline Fragmented Forest & 12.59 & 7.52 & 12.14 & 1 & $<0.01$ \\
\hline Intact Forest & 14.48 & 7.92 & 6.16 & 1 & 0.02 \\
\hline Peromyscus spp. ${ }^{a}$ & 11.87 & 12.32 & 0.08 & 1 & 0.78 \\
\hline Grassland & 13.50 & 20.40 & 5.12 & 1 & 0.03 \\
\hline Fragmented Forest & 10.79 & 6.00 & 19.98 & 1 & $<0.01$ \\
\hline Intact Forest & 11.33 & 6.63 & 4.07 & 1 & 0.05 \\
\hline Eastern chipmunk $^{\mathrm{a}}$ & 0.32 & 0.27 & 0.11 & 1 & 0.74 \\
\hline Grassland $^{\mathrm{c}}$ & 0.00 & 0.07 & - & & \\
\hline Fragmented Forest & 0.08 & 0.06 & 0.03 & 1 & 0.85 \\
\hline Intact Forest & 0.89 & 0.84 & 0.01 & 1 & 0.91 \\
\hline Northern short-tailed shrew ${ }^{\mathrm{a}}$ & 1.07 & 0.05 & 20.51 & 1 & $<0.01$ \\
\hline Grassland & 0.21 & 0.00 & 1.26 & 1 & 0.27 \\
\hline Fragmented Forest & 0.92 & 0.17 & 4.23 & 1 & 0.047 \\
\hline Intact Forest & 2.07 & 0.00 & 13.96 & 1 & $<0.01$ \\
\hline \multicolumn{6}{|l|}{ House mouse } \\
\hline Grassland $^{\mathrm{d}}$ & 1.91 & 0.97 & 0.89 & 1 & 0.35 \\
\hline
\end{tabular}

${ }^{\mathrm{a}}$ Analysis performed on treatments combined in these rows.

${ }^{\mathrm{b}}$ Species were selected for comparisons where sample size was sufficiently large.

${ }^{\mathrm{c}}$ Sample size insufficient for analysis.

${ }^{\mathrm{d}}$ House mouse was captured only in grassland treatment. 
Table 3. Similarity indices comparing small mammal community composition among grassland, shrub/pole, fragmented forest, and intact forest treatments on MTMVF landscapes in southern West Virginia based on Sherman trapping and drift fence array trapping.

\begin{tabular}{|c|c|c|c|c|c|c|c|c|c|c|c|}
\hline \multirow[b]{3}{*}{ Comparison } & \multicolumn{6}{|c|}{ Sherman Trapping ${ }^{a}$} & \multicolumn{3}{|c|}{ Drift Fence Array Trapping } & \multicolumn{2}{|c|}{ Both Methods ${ }^{b}$} \\
\hline & \multicolumn{2}{|c|}{ Shared Spp. } & \multicolumn{2}{|c|}{ Jaccard $^{\mathrm{c}}$} & \multicolumn{2}{|c|}{ Renkonen } & \multirow[t]{2}{*}{ Shared Spp. } & \multirow[t]{2}{*}{ Jaccard } & \multirow[t]{2}{*}{ Renkonen } & \multirow[t]{2}{*}{ Shared Spp. } & \multirow[t]{2}{*}{ Jaccard } \\
\hline & 1999 & 2000 & 1999 & 2000 & 1999 & 2000 & & & & & \\
\hline Grassland/Intact & 2 & 2 & 0.25 & 0.29 & 0.79 & 0.83 & 7 & 0.58 & 0.54 & 9 & 0.69 \\
\hline Grassland/Fragment & 2 & 2 & 0.22 & 0.22 & 0.86 & 0.81 & 9 & 0.82 & 0.58 & 11 & 0.85 \\
\hline Fragment/Intact & 4 & 2 & 0.57 & 0.33 & 0.87 & 0.86 & 8 & 0.73 & 0.69 & 9 & 0.82 \\
\hline Shrub/pole/Intact & - & 1 & - & 0.17 & - & 0.83 & 8 & 0.80 & 0.70 & 8 & 0.73 \\
\hline Shrub/pole/Fragment & - & 1 & - & 0.13 & - & 0.80 & 9 & 0.90 & 0.61 & 9 & 0.75 \\
\hline Shrub/pole/Grassland & - & 2 & - & 0.25 & - & 0.93 & 9 & 0.90 & 0.77 & 9 & 0.64 \\
\hline
\end{tabular}

${ }^{\mathrm{a}}$ Indices were calculated for each year separately for Sherman trapping data because shrub/pole treatment was not sampled in 1999.

${ }^{\mathrm{b}}$ Renkonen indices could not be calculated because abundance values from Sherman and array trapping are not comparable.

${ }^{\mathrm{c}}$ Jaccard index is based on the number of species shared while the Renkonen index takes into account the proportion of each species present in each treatment (in all cases the scale ranges from $0=$ no similarity to $1=$ complete similarity). 
Table 4. Relative abundance (mammals/100 trap nights), and standard error (SE) of Peromyscus spp. age and sex groups, and adult/juvenile ratios in grassland, shrub/pole, fragmented forest, and intact forest treatments based on Sherman trapping on MTMVF landscapes in southern West Virginia for 1999 and 2000.

\begin{tabular}{|c|c|c|c|c|c|c|c|c|c|c|c|c|c|c|}
\hline & \multicolumn{12}{|c|}{ Treatment } & \multirow{2}{*}{\multicolumn{2}{|c|}{ ANOVA Results }} \\
\hline & \multicolumn{3}{|c|}{ Grassland } & \multicolumn{3}{|c|}{ Shrub/Pole } & \multicolumn{3}{|c|}{ Fragmented Forest } & \multicolumn{3}{|c|}{ Intact Forest } & & \\
\hline & Mean & SE & $\mathrm{N}^{\mathrm{a}}$ & Mean & $\mathrm{SE}$ & $\mathrm{N}$ & Mean & SE & $\overline{\mathrm{N}}$ & Mean & SE & $\mathrm{N}$ & $\mathrm{F}$ & $P$ \\
\hline \multicolumn{15}{|l|}{1999} \\
\hline Adult Males & $4.0 \mathrm{~A}^{\mathrm{b}}$ & 2.8 & 16 & $--^{c}$ & - & - & $1.8 \mathrm{~B}$ & 1.4 & 16 & $1.4 \mathrm{~B}$ & 1.6 & 16 & 8.20 & 0.0012 \\
\hline Adult Females & $2.1 \mathrm{~A}$ & 1.4 & 16 & - & - & - & $1.9 \mathrm{AB}$ & 1.2 & 16 & $1.0 \mathrm{~B}$ & 1.2 & 16 & 3.51 & 0.0404 \\
\hline Juvenile Males & $4.5 \mathrm{~A}$ & 3.3 & 16 & - & - & - & $3.9 \mathrm{~A}$ & 1.5 & 16 & $5.3 \mathrm{~A}$ & 4.0 & 16 & 1.03 & 0.3656 \\
\hline Juvenile Females & $2.2 \mathrm{~A}$ & 2.0 & 16 & - & - & - & $3.1 \mathrm{~A}$ & 2.1 & 16 & $3.6 \mathrm{~A}$ & 2.7 & 16 & 2.11 & 0.1356 \\
\hline Adult/Juvenile Ratio $^{\mathrm{d}}$ & $1: 1.1$ & & & & & & $1: 1.9$ & & & $1: 3.7$ & & & & \\
\hline \multicolumn{15}{|l|}{2000} \\
\hline Adult Males & $6.2 \mathrm{~A}$ & 4.9 & 20 & $5.9 \mathrm{~A}$ & 3.8 & 12 & $2.3 \mathrm{~B}$ & 1.9 & 20 & $1.1 \mathrm{~B}$ & 1.8 & 20 & 13.13 & $<0.0001$ \\
\hline Adult Females & $5.7 \mathrm{~A}$ & 4.0 & 20 & $6.2 \mathrm{~A}$ & 4.2 & 12 & $1.8 \mathrm{~B}$ & 1.4 & 20 & $1.9 \mathrm{~B}$ & 2.1 & 20 & 14.54 & $<0.0001$ \\
\hline Juvenile Males & $4.6 \mathrm{~A}$ & 4.0 & 20 & $3.9 \mathrm{AB}$ & 2.1 & 12 & $1.3 \mathrm{C}$ & 1.2 & 20 & $2.5 \mathrm{BC}$ & 3.0 & 20 & 5.99 & 0.0013 \\
\hline Juvenile Females & $3.8 \mathrm{~A}$ & 3.7 & 20 & $2.9 \mathrm{~A}$ & 2.5 & 12 & $0.7 \mathrm{~B}$ & 1.1 & 20 & 1.2B & 3.0 & 20 & 7.50 & 0.0003 \\
\hline Adult/Juvenile Ratio & $1: 0.7$ & & & $1: 0.6$ & & & $1: 0.5$ & & & $1: 1.2$ & & & & \\
\hline
\end{tabular}

${ }^{\mathrm{a}} \mathrm{N}=$ number of trapping sessions multiplied by the number of transects in a given treatment.

${ }^{\mathrm{b}}$ Means followed by different letters within years are significantly different (Waller-Duncan k-ratio $t$-test, $P \leq 0.05$ ).

${ }^{c}$ The shrub/pole treatment was not sampled in 1999.

${ }^{\mathrm{d}}$ Ratio of 1 adult : $\mathrm{x}$ juveniles. Higher numbers in the divisor suggest greater production. 
Table 5. Percentage of Peromyscus spp. adults in reproductive condition in grassland, shrub/pole, fragmented forest, and intact forest treatments based on Sherman trapping on reclaimed MTMVF landscapes in southern West Virginia in 1999 and 2000.

\begin{tabular}{|c|c|c|c|c|c|c|c|c|c|c|c|}
\hline \multirow[b]{3}{*}{ Comparison } & \multicolumn{8}{|c|}{ Treatment } & & & \\
\hline & \multicolumn{2}{|c|}{ Grassland } & \multicolumn{2}{|c|}{ Shrub/Pole } & \multicolumn{2}{|c|}{ Fragmented Forest } & \multicolumn{2}{|c|}{ Intact Forest } & \multicolumn{3}{|c|}{ ANOVA Results } \\
\hline & $\%$ & $\mathrm{~N}^{\mathrm{a}}$ & $\%$ & $\mathrm{~N}$ & $\%$ & $\mathrm{~N}$ & $\%$ & $\mathrm{~N}$ & $\mathrm{~F}$ & $\mathrm{df}$ & $P$ \\
\hline \multicolumn{12}{|c|}{ Among Treatments } \\
\hline \multicolumn{12}{|c|}{1999} \\
\hline Males & $65.5 \mathrm{~A}^{\mathrm{b}}$ & 14 & $-{ }^{\mathrm{c}}$ & & $39.9 \mathrm{~B}$ & 15 & $25.4 \mathrm{~B}$ & 16 & 7.18 & 2 & 0.0026 \\
\hline Females & $41.9 \mathrm{~A}$ & 15 & - & & $13.4 \mathrm{~B}$ & 16 & $4.0 \mathrm{~B}$ & 16 & 9.11 & 2 & 0.0002 \\
\hline Total & $48.3 \mathrm{~A}$ & 16 & - & & $25.0 \mathrm{~B}$ & 16 & $12.0 \mathrm{C}$ & 16 & 11.33 & 2 & 0.0002 \\
\hline \multicolumn{12}{|l|}{2000} \\
\hline Males & $79.8 \mathrm{~A}$ & 19 & $85.3 \mathrm{~A}$ & 11 & $83.3 \mathrm{~A}$ & 16 & $82.5 \mathrm{~A}$ & 19 & 0.45 & 3 & 0.7179 \\
\hline Females & $55.8 \mathrm{~A}$ & 19 & $68.3 \mathrm{~A}$ & 12 & $54.5 \mathrm{~A}$ & 19 & $22.6 \mathrm{~B}$ & 16 & 4.57 & 3 & 0.0068 \\
\hline Total & $66.2 \mathrm{~A}$ & 20 & $74.7 \mathrm{~A}$ & 12 & $63.2 \mathrm{~A}$ & 19 & $52.5 \mathrm{~A}$ & 16 & 1.05 & 3 & 0.3802 \\
\hline
\end{tabular}

$\underline{B e t w e e n ~ Y e a r s ~}^{\mathrm{d}}$

\begin{tabular}{|c|c|c|c|c|c|c|c|c|c|c|c|c|c|c|}
\hline ANOVA Results & $\mathrm{F}$ & $\mathrm{df}$ & $P$ & & & & & & $P$ & $\mathrm{~F}$ & $\mathrm{df}$ & $P$ & & \\
\hline Males & 0.88 & 1 & 0.3586 & - & - & - & 19.19 & 1 & 0.0002 & 33.73 & 1 & $<0.0001$ & - & \\
\hline Females & 1.51 & 1 & 0.2302 & - & - & - & 14.50 & 1 & 0.0008 & 0.39 & 1 & 0.5360 & - & . \\
\hline Total & 3.32 & 1 & 0.0795 & - & - & - & 17.33 & 1 & 0.0003 & 15.42 & 1 & 0.0007 & - & - \\
\hline
\end{tabular}

${ }^{\mathrm{a}} \mathrm{N}=$ number of trapping sessions multiplied by the number of transects in a given treatment.

${ }^{\mathrm{b}}$ Means followed by different letters within a row are significantly different from one another (Waller-Duncan k-ratio $t$-test, $P \leq 0.05$ ).

${ }^{c}$ The shrub/pole treatment was not sampled in 1999.

${ }^{\mathrm{d}}$ Comparisons between years were performed within treatments. 
Table 6. Mean and standard error (SE) of habitat variables measured at Sherman trapping sites in grassland $(\mathrm{N}=10)$, shrub/pole $(\mathrm{N}=6)$, fragmented forest $(\mathrm{N}=10)$, and intact forest $(\mathrm{N}=10)$ treatments on MTMVF landscapes in southern West Virginia in 1999.

\begin{tabular}{|c|c|c|c|c|c|c|c|c|c|c|}
\hline \multirow[b]{3}{*}{ Variables } & \multicolumn{8}{|c|}{ Treatment } & & \\
\hline & \multicolumn{2}{|c|}{ Grassland } & \multicolumn{2}{|c|}{ Shrub/Pole } & \multicolumn{2}{|c|}{ Fragmented Forest } & \multicolumn{2}{|c|}{ Intact Forest } & \multicolumn{2}{|c|}{ ANOVA Results } \\
\hline & Mean & $\mathrm{SE}$ & Mean & $\mathrm{SE}$ & Mean & SE & Mean & $\mathrm{SE}$ & $\mathrm{F}$ & $P$ \\
\hline Slope (\%) & $14.80 \mathrm{~A}^{\mathrm{b}}$ & 3.22 & $9.42 \mathrm{~A}$ & 4.33 & $7.80 \mathrm{~A}$ & 5.22 & $8.08 \mathrm{~A}$ & 4.39 & 0.60 & 0.6224 \\
\hline Elevation (m) & $400.93 \mathrm{~A}$ & 7.19 & $378.85 \mathrm{~A}$ & 11.53 & $332.08 \mathrm{~A}$ & 7.11 & $389.58 \mathrm{~A}$ & 10.87 & 2.21 & 0.1063 \\
\hline Aspect Code & 1.19B & 0.18 & $1.46 \mathrm{AB}$ & 0.26 & $1.93 \mathrm{~A}$ & 0.06 & $1.64 \mathrm{AB}$ & 0.20 & 3.48 & 0.0271 \\
\hline Litter Depth $(\mathrm{cm})$ & $2.18 \mathrm{~A}$ & 0.31 & $1.87 \mathrm{~A}$ & 0.23 & - & - & - & - & 0.48 & 0.4977 \\
\hline Robel Pole Index & $2.69 \mathrm{~A}$ & 0.38 & $3.73 \mathrm{~A}$ & 0.11 & - & - & - & - & 4.31 & 0.0569 \\
\hline Canopy Height (m) & - & - & $13.29 \mathrm{C}$ & 2.68 & $20.76 \mathrm{~B}$ & 1.28 & $25.71 \mathrm{~A}$ & 1.42 & 12.24 & 0.0002 \\
\hline Distance to Edge (m) & $68.10 \mathrm{~A}$ & 26.20 & $29.63 \mathrm{AB}$ & 13.92 & $12.08 \mathrm{~B}$ & 6.35 & $2.69 \mathrm{~B}$ & 0.95 & 3.32 & 0.0329 \\
\hline \multicolumn{11}{|l|}{ Ground Cover $(\%)$} \\
\hline Water & $0.00 \mathrm{~B}$ & 0.00 & $0.00 \mathrm{~B}$ & 0.00 & $4.50 \mathrm{~A}$ & 0.90 & $1.38 \mathrm{~B}$ & 0.60 & 12.73 & $<0.0001$ \\
\hline Bare ground & $12.63 \mathrm{~A}$ & 3.48 & $3.13 \mathrm{~A}$ & 2.13 & $9.42 \mathrm{~A}$ & 2.58 & $10.13 \mathrm{~A}$ & 1.90 & 1.71 & 0.1838 \\
\hline Litter & $13.75 \mathrm{C}$ & 3.52 & $4.38 \mathrm{C}$ & 2.54 & $41.08 \mathrm{~B}$ & 4.32 & $52.75 \mathrm{~A}$ & 3.54 & 33.61 & $<0.0001$ \\
\hline Woody Debris & $0.00 \mathrm{~B}$ & 0.00 & $0.00 \mathrm{~B}$ & 0.00 & $3.92 \mathrm{~A}$ & 1.04 & $4.63 \mathrm{~A}$ & 0.79 & 11.43 & $<0.0001$ \\
\hline Green & $72.38 \mathrm{~A}$ & 4.79 & $87.50 \mathrm{~B}$ & 5.48 & $38.08 \mathrm{C}$ & 2.85 & $29.50 \mathrm{C}$ & 2.73 & 42.52 & $<0.0001$ \\
\hline \multicolumn{11}{|c|}{ Stem Densities (no./plot) } \\
\hline$<8 \mathrm{~cm}$ & $42.38 \mathrm{~A}$ & 4.51 & $27.25 \mathrm{~A}$ & 5.27 & $53.78 \mathrm{~A}$ & 12.53 & $34.03 \mathrm{~A}$ & 6.02 & 1.74 & 0.1789 \\
\hline $8-38 \mathrm{~cm}$ & $0.00 \mathrm{~B}$ & 0.00 & $3.25 \mathrm{~B}$ & 1.07 & $14.80 \mathrm{~A}$ & 1.85 & $15.23 \mathrm{~A}$ & 1.84 & 28.56 & $<0.0001$ \\
\hline$>38 \mathrm{~cm}$ & $0.00 \mathrm{~B}$ & 0.00 & $0.00 \mathrm{~B}$ & 0.00 & $2.00 \mathrm{~A}$ & 0.24 & $1.68 \mathrm{~A}$ & 0.27 & 26.85 & $<0.0001$ \\
\hline \multicolumn{11}{|l|}{ Canopy Cover $(\%)$} \\
\hline$>0.5-3 \mathrm{~m}$ & - & - & $27.5 \mathrm{~A}$ & 6.35 & $42.58 \mathrm{~A}$ & 3.78 & $36.75 \mathrm{~A}$ & 4.96 & 2.08 & 0.1474 \\
\hline$>3-6 \mathrm{~m}$ & - & - & $17.92 \mathrm{~B}$ & 5.19 & $59.67 \mathrm{~A}$ & 5.15 & $61.38 \mathrm{~A}$ & 4.83 & 18.23 & $<0.0001$ \\
\hline$>6-12 \mathrm{~m}$ & - & - & 7.71B & 2.78 & $65.25 \mathrm{~A}$ & 4.26 & $61.88 \mathrm{~A}$ & 4.91 & 41.25 & $<0.0001$ \\
\hline$>12 \mathrm{~m}$ & - & - & $0.00 \mathrm{~B}$ & 0.00 & $70.38 \mathrm{~A}$ & 7.05 & $79.38 \mathrm{~A}$ & 4.78 & 46.24 & $<0.0001$ \\
\hline
\end{tabular}

\footnotetext{
${ }^{a}$ Percentage variables were arcsine square root transformed before running ANOVA; actual data presented in table.

${ }^{\mathrm{b}}$ Means followed by different letters within rows are significantly different (Waller-Duncan k-ratio $t$-test, $P \leq 0.05$ ).

${ }^{c}$ Azimuth transformed using Beers transformation $(\cos [45-\mathrm{x}]+1)$.

${ }^{\mathrm{d}}$ Indicates variables not measured in a treatment.
} 
Table 7. Mean and standard error (SE) of habitat variables measured at drift fence array trapping sites in grassland $(\mathrm{N}=3)$, shrub/pole $(\mathrm{N}=3)$, fragmented forest $(\mathrm{N}=3)$, and intact forest $(\mathrm{N}=3)$ treatments on MTMVF landscapes in southern West Virginia in 2000.

\begin{tabular}{|c|c|c|c|c|c|c|c|c|c|c|}
\hline \multirow[b]{3}{*}{ Variables } & \multicolumn{8}{|c|}{ Treatment } & & \\
\hline & \multicolumn{2}{|c|}{ Grassland } & \multicolumn{2}{|c|}{ Shrub/Pole } & \multicolumn{2}{|c|}{ Fragmented Forest } & \multicolumn{2}{|c|}{ Intact Forest } & \multicolumn{2}{|c|}{ ANOVA Results } \\
\hline & Mean & $\mathrm{SE}$ & Mean & $\mathrm{SE}$ & Mean & $\mathrm{SE}$ & Mean & $\mathrm{SE}$ & $\mathrm{F}$ & $P$ \\
\hline Slope $(\%)$ & $20.67 \mathrm{~A}$ & 8.97 & $4.42 \mathrm{~A}$ & 4.42 & $28.42 \mathrm{~A}$ & 7.53 & $22.58 \mathrm{~A}$ & 9.38 & 1.73 & 0.2385 \\
\hline Elevation (m) & $413.67 \mathrm{~A}$ & 37.95 & $412.00 \mathrm{~A}$ & 39.53 & $335.00 \mathrm{~A}$ & 20.95 & $444.67 \mathrm{~A}$ & 66.23 & 1.11 & 0.3986 \\
\hline Aspect Code & $1.62 \mathrm{~A}$ & 0.06 & $0.60 \mathrm{~B}$ & 0.57 & $0.73 \mathrm{~B}$ & 0.14 & $0.68 \mathrm{~B}$ & 0.13 & 5.17 & 0.0340 \\
\hline Litter Depth (cm) & $2.60 \mathrm{~A}$ & 1.04 & $1.06 \mathrm{~A}$ & 0.43 & - & - & - & - & 1.89 & 0.2409 \\
\hline Robel Pole Index & $3.07 \mathrm{~A}$ & 0.71 & $4.98 \mathrm{~A}$ & 0.40 & - & - & - & - & 5.50 & 0.0789 \\
\hline Canopy Height (m) & - & - & $3.37 \mathrm{~B}$ & 0.76 & $22.88 \mathrm{~A}$ & 1.59 & $22.38 \mathrm{~A}$ & 1.86 & 56.61 & 0.0001 \\
\hline Distance to Edge (m) & $94.00 \mathrm{~A}$ & 48.19 & $61.00 \mathrm{~A}$ & 8.79 & $54.92 \mathrm{~A}$ & 19.44 & $118.75 \mathrm{~A}$ & 91.04 & 0.32 & 0.8099 \\
\hline \multicolumn{11}{|l|}{ Ground Cover (\%) } \\
\hline Water & $0.00 \mathrm{~A}$ & 0.00 & $1.67 \mathrm{~A}$ & 1.10 & $0.83 \mathrm{~A}$ & 0.83 & $0.00 \mathrm{~A}$ & 0.00 & 1.33 & 0.3300 \\
\hline Bare ground & $6.67 \mathrm{~A}$ & 3.97 & $2.50 \mathrm{~A}$ & 0.72 & $4.58 \mathrm{~A}$ & 2.92 & $5.42 \mathrm{~A}$ & 1.67 & 0.44 & 0.7278 \\
\hline Litter & $12.08 \mathrm{~B}$ & 7.65 & $8.33 \mathrm{~B}$ & 8.33 & $55.83 \mathrm{~A}$ & 1.10 & $44.17 \mathrm{~A}$ & 6.71 & 12.70 & 0.0021 \\
\hline Woody Debris & $0.00 \mathrm{~A}$ & 0.00 & $0.00 \mathrm{~A}$ & 0.00 & $2.50 \mathrm{~A}$ & 1.91 & $4.17 \mathrm{~A}$ & 2.32 & 1.85 & 0.2170 \\
\hline Green & $81.25 \mathrm{~A}$ & 6.29 & $79.17 \mathrm{~A}$ & 16.49 & $31.67 \mathrm{~B}$ & 1.82 & $44.17 \mathrm{~B}$ & 7.92 & 6.60 & 0.0148 \\
\hline \multicolumn{11}{|c|}{$\underline{\text { Stem Densities (no./plot) }}$} \\
\hline$<8 \mathrm{~cm}$ & $1.67 \mathrm{~A}$ & 1.67 & $96.25 \mathrm{~A}$ & 49.94 & $50.00 \mathrm{~A}$ & 9.71 & $71.67 \mathrm{~A}$ & 14.62 & 2.30 & 0.1535 \\
\hline $8-38 \mathrm{~cm}$ & $0.00 \mathrm{C}$ & 0.00 & $4.08 \mathrm{BC}$ & 1.33 & $12.42 \mathrm{AB}$ & 4.04 & $16.00 \mathrm{~A}$ & 4.93 & 5.12 & 0.0289 \\
\hline$>38 \mathrm{~cm}$ & $0.00 \mathrm{~B}$ & 0.00 & $0.00 \mathrm{~B}$ & 0.00 & $2.33 \mathrm{~A}$ & 0.51 & $0.58 \mathrm{~B}$ & 0.08 & 18.48 & 0.0006 \\
\hline \multicolumn{11}{|l|}{ Canopy Cover (\%) } \\
\hline$>0.5-3 \mathrm{~m}$ & - & - & $19.58 \mathrm{~B}$ & 9.31 & $64.58 \mathrm{~A}$ & 4.81 & $40.00 \mathrm{AB}$ & 12.50 & 5.73 & 0.0406 \\
\hline$>3-6 \mathrm{~m}$ & - & - & $16.00 \mathrm{~B}$ & 12.01 & $75.42 \mathrm{~A}$ & 7.92 & $45.83 \mathrm{AB}$ & 5.32 & 11.25 & 0.0093 \\
\hline$>6-12 \mathrm{~m}$ & - & - & $7.58 \mathrm{~B}$ & 7.46 & $67.50 \mathrm{~A}$ & 10.63 & $53.33 \mathrm{~A}$ & 5.12 & 15.10 & 0.0046 \\
\hline$>12 \mathrm{~m}$ & - & - & $0.00 \mathrm{~B}$ & 0.00 & $65.83 \mathrm{~A}$ & 7.58 & $57.08 \mathrm{~A}$ & 3.41 & 55.49 & 0.0001 \\
\hline
\end{tabular}

${ }^{a}$ Percentage variables were arcsine square root transformed before running ANOVA; actual data presented in table.

${ }^{\mathrm{b}}$ Means followed by different letters within rows are significantly different (Waller-Duncan k-ratio $t$-test, $P \leq 0.05$ ).

${ }^{\mathrm{c}}$ Azimuth transformed using Beers transformation $(\cos [45-\mathrm{x}]+1)$.

${ }^{\mathrm{d}}$ Indicates variables not measured in a treatment. 
Table 8. Significant variables from multiple linear regressions of mammal species richness, total abundance, and Peromyscus spp. abundance on habitat and environmental variables in grassland, shrub/pole, fragmented forest, intact forest treatments on MTMVF landscapes in southern West Virginia.

\begin{tabular}{|c|c|c|c|c|c|}
\hline Variable & Parameter Estimate & $\mathrm{F}$ & $P$ & Partial $R^{2}$ & Model $R^{2}$ \\
\hline \multicolumn{6}{|c|}{ Grassland Treatment - Sherman Trapping } \\
\hline \multicolumn{6}{|c|}{ Richness } \\
\hline Distance to edge (m) & -0.0032 & 4.61 & 0.0391 & 0.1194 & 0.1194 \\
\hline \multicolumn{6}{|l|}{ Total Abundance } \\
\hline Green groundcover $(\%)$ & 99.9693 & 5.19 & 0.0295 & 0.3699 & 0.3699 \\
\hline Precipitation $(\mathrm{cm})$ & 2.1868 & 5.79 & 0.0221 & 0.0673 & 0.4372 \\
\hline Bare ground (\%) & -44.4321 & 4.08 & 0.0518 & 0.0637 & 0.5009 \\
\hline \multicolumn{6}{|l|}{ Peromyscus spp. } \\
\hline Bare ground (\%) & -68.4643 & 27.31 & $<0.0001$ & 0.4454 & 0.4454 \\
\hline Precipitation $(\mathrm{cm})$ & 1.9397 & 6.75 & 0.0139 & 0.0942 & 0.5396 \\
\hline Green groundcover $(\%)$ & 89.5016 & 4.78 & 0.0362 & 0.0598 & 0.5994 \\
\hline \multicolumn{6}{|c|}{ Grassland Treatment - Array Trapping } \\
\hline \multicolumn{6}{|c|}{ Richness } \\
\hline Precipitation $(\mathrm{cm})$ & -1.4296 & 7.32 & 0.0103 & 0.1651 & 0.1651 \\
\hline Distance to Edge (m) & -0.0089 & 8.26 & 0.0068 & 0.1559 & 0.3210 \\
\hline \multicolumn{6}{|l|}{ Total Abundance } \\
\hline Precipitation $(\mathrm{cm})$ & -9.1334 & 6.52 & 0.0149 & 0.1499 & 0.1499 \\
\hline Distance to Edge (m) & -0.0552 & 6.79 & 0.0132 & 0.1349 & 0.2848 \\
\hline \multicolumn{6}{|l|}{ Peromyscus spp. } \\
\hline Slope $(\%)$ & -0.1161 & 3.36 & 0.0750 & 0.0832 & 0.0832 \\
\hline Precipitation $(\mathrm{cm})$ & -3.1756 & 3.11 & 0.0861 & 0.0730 & 0.1562 \\
\hline \multicolumn{6}{|l|}{ Southern Bog Lemming } \\
\hline Aspect & -11.9301 & 5.36 & 0.0262 & 0.1266 & 0.1266 \\
\hline \multicolumn{6}{|l|}{ Masked shrew } \\
\hline Moon Phase (\% Illuminated) & -5.1862 & 5.84 & 0.0207 & 0.1364 & 0.1364 \\
\hline \multicolumn{6}{|c|}{ Fragmented Forest and Intact Forest Treatments - Sherman Trapping } \\
\hline \multicolumn{6}{|c|}{ Richness } \\
\hline Precipitation $(\mathrm{cm})$ & -0.2319 & 7.20 & 0.0092 & 0.0983 & 0.0983 \\
\hline Low Temperature $\left({ }^{\circ} \mathrm{C}\right)$ & -0.0952 & 8.86 & 0.0041 & 0.1082 & 0.2065 \\
\hline Bare ground $(\%)$ & 1.0863 & 2.92 & 0.0926 & 0.0346 & 0.2411 \\
\hline \multicolumn{6}{|l|}{ Total Abundance } \\
\hline Precipitation $(\mathrm{cm})$ & -2.7821 & 16.37 & 0.0001 & 0.1988 & 0.1988 \\
\hline Low Temperature $\left({ }^{\circ} \mathrm{C}\right)$ & -0.6370 & 8.34 & 0.0053 & 0.0911 & 0.2899 \\
\hline Aspect & -6.0673 & 8.32 & 0.0053 & 0.0817 & 0.3716 \\
\hline Canopy Cover $>0.5-3 \mathrm{~m}(\%)$ & -0.1311 & 3.83 & 0.0548 & 0.0337 & 0.4053 \\
\hline Canopy Height (m) & -0.3352 & 3.30 & 0.0743 & 0.0280 & 0.4333 \\
\hline
\end{tabular}


Table 8. Continued.

\begin{tabular}{lrrrrr}
\hline Variable & Parameter Estimate & F & $P$ & Partial $R^{2}$ & Model $R^{2}$ \\
\hline Peromyscus spp. & & & & & \\
Precipitation (cm) & -1.4116 & 12.36 & 0.0008 & 0.1578 & 0.1578 \\
Aspect & -6.9023 & 11.19 & 0.0014 & 0.1237 & 0.2815 \\
Moon Phase (\% Illuminated) & -8.1435 & 6.62 & 0.0124 & 0.0674 & 0.3489 \\
Canopy Cover $>0.5-3$ m (\%) & -0.1216 & 6.42 & 0.0138 & 0.0602 & 0.4091 \\
Canopy Height (m) & -0.3260 & 7.96 & 0.0064 & 0.0672 & 0.4763 \\
Light Index & 8.6643 & 6.82 & 0.0114 & 0.0526 & 0.5289
\end{tabular}

Fragmented Forest and Intact Forest Treatments - Array Trapping

Richness

\begin{tabular}{|c|c|c|c|c|c|}
\hline Moon Phase (\% Illuminated) & 1.5465 & 13.54 & 0.0004 & 0.1512 & 0.1512 \\
\hline Stem Density $<8$ cm DBH & -0.0387 & 11.85 & 0.0009 & 0.1158 & 0.2670 \\
\hline Low Temperature $\left({ }^{\circ} \mathrm{C}\right)$ & 0.0808 & 7.48 & 0.0078 & 0.0673 & 0.3343 \\
\hline Woody Debris (\%) & -11.5432 & 4.86 & 0.0306 & 0.0416 & 0.3759 \\
\hline \multicolumn{6}{|l|}{ Total Abundance } \\
\hline Moon Phase (\% Illuminated) & 12.5103 & 12.53 & 0.0007 & 0.1416 & 0.1416 \\
\hline Stem Density $<8 \mathrm{~cm} \mathrm{DBH}$ & -0.1340 & 5.59 & 0.0206 & 0.0596 & 0.2012 \\
\hline \multicolumn{6}{|l|}{ Peromyscus spp. } \\
\hline Moon Phase (\% Illuminated) & 5.2437 & 4.06 & 0.0473 & 0.0508 & 0.0508 \\
\hline Low Temperature $\left({ }^{\circ} \mathrm{C}\right)$ & -0.2946 & 6.25 & 0.0146 & 0.1238 & 0.1746 \\
\hline Canopy Cover 0.5-3 m (\%) & -0.0839 & 4.13 & 0.0458 & 0.1701 & 0.3447 \\
\hline \multicolumn{6}{|l|}{ Woodland Vole } \\
\hline Elevation (m) & 0.0050 & 7.69 & 0.0070 & 0.0919 & 0.0919 \\
\hline Moon Phase (\% Illuminated) & 1.0392 & 4.43 & 0.0387 & 0.0506 & 0.1425 \\
\hline Slope $(\%)$ & 0.0260 & 3.62 & 0.0610 & 0.0400 & 0.1825 \\
\hline \multicolumn{6}{|l|}{ Masked shrew } \\
\hline Elevation (m) & 0.0100 & 9.85 & 0.0024 & 0.1148 & 0.1148 \\
\hline Light Index & 2.0912 & 5.4 & 0.0228 & 0.0595 & 0.1743 \\
\hline Canopy Height (m) & 0.2634 & 3.61 & 0.0615 & 0.0384 & 0.2127 \\
\hline Stem Density $<8 \mathrm{~cm}$ DBH & -0.0226 & 3.15 & 0.0803 & 0.0325 & 0.2452 \\
\hline
\end{tabular}

$\underline{\text { Shrub/pole, Fragmented Forest, and Intact Forest Treatments - Sherman Trapping }}$

Richness

$\begin{array}{lrrrrr}\text { Low Temperature }\left({ }^{\circ} \mathrm{C}\right) & -0.0912 & 8.61 & 0.0044 & 0.0995 & 0.0995 \\ \text { Precipitation }(\mathrm{cm}) & -0.2039 & 9.43 & 0.0030 & 0.0982 & 0.1977 \\ \quad \text { Bare ground (\%) } & 1.0570 & 4.60 & 0.0351 & 0.0458 & 0.2435 \\ \quad \begin{array}{r}\text { Total Abundance } \\ \text { Canopy Cover }>0.5-3 \mathrm{~m}(\%)\end{array} & -16.4071 & 21.03 & <0.0001 & 0.2123 & 0.2123 \\ \quad \text { Canopy Height (m) } & -0.5107 & 8.82 & 0.0040 & 0.0809 & 0.2932 \\ \text { Precipitation }(\mathrm{cm}) & -2.0173 & 9.88 & 0.0024 & 0.0813 & 0.3745 \\ \text { Bare ground }(\%) & 16.6469 & 11.43 & 0.0011 & 0.0827 & 0.4572 \\ \text { Low Temperature }\left({ }^{\circ} \mathrm{C}\right) & -0.6224 & 9.16 & 0.0034 & 0.0598 & 0.5170 \\ \text { Peromyscus } \text { spp. } & & & & & \\ \text { Canopy Cover }>0.5-3 \mathrm{~m}(\%) & -17.0509 & 34.86 & <0.0001 & 0.3088 & 0.3088 \\ \text { Canopy Height (m) } & -0.4884 & 12.35 & 0.0007 & 0.0955 & 0.4044 \\ \text { Bare ground }(\%) & 12.2341 & 7.32 & 0.0084 & 0.0523 & 0.4567 \\ \text { Precipitation }(\mathrm{cm}) & -1.3118 & 8.11 & 0.0057 & 0.0530 & 0.5098\end{array}$


Table 8. Continued.

\begin{tabular}{|c|c|c|c|c|c|}
\hline Variable & Parameter Estimate & $\mathrm{F}$ & $P$ & Partial $R^{2}$ & Model $R^{2}$ \\
\hline \multicolumn{6}{|c|}{ Shrub/pole, Fragmented Forest, and Intact Forest Treatments - Array Trapping } \\
\hline \multicolumn{6}{|c|}{ Richness } \\
\hline Moon Phase (\% Illuminated) & 1.2046 & 8.33 & 0.0047 & 0.0676 & 0.0676 \\
\hline Stem Density $<8 \mathrm{~cm} \mathrm{DBH}$ & -0.0274 & 7.70 & 0.0064 & 0.0590 & 0.1266 \\
\hline Aspect & 0.9093 & 5.01 & 0.0272 & 0.0371 & 0.1637 \\
\hline Stem Density $>8-38 \mathrm{~cm} \mathrm{DBH}$ & -0.0385 & 3.02 & 0.0851 & 0.0219 & 0.1856 \\
\hline \multicolumn{6}{|l|}{ Total Abundance } \\
\hline Moon Phase (\% Illuminated) & 11.1214 & 10.35 & 0.0017 & 0.0826 & 0.0826 \\
\hline Low Temperature $\left({ }^{\circ} \mathrm{C}\right)$ & -0.4218 & 5.71 & 0.0185 & 0.0437 & 0.1263 \\
\hline Canopy Cover >12 m (\%) & -0.0511 & 4.45 & 0.0371 & 0.0331 & 0.1594 \\
\hline \multicolumn{6}{|l|}{ Peromyscus spp. } \\
\hline Low Temperature $\left({ }^{\circ} \mathrm{C}\right)$ & -0.3500 & 8.23 & 0.0049 & 0.0668 & 0.0668 \\
\hline Moon Phase (\% Illuminated) & 5.0240 & 10.88 & 0.0013 & 0.0813 & 0.1481 \\
\hline Canopy Cover 0.5-3 m (\%) & -0.0605 & 3.25 & 0.0741 & 0.0228 & 0.1709 \\
\hline Aspect & 4.1038 & 1.60 & 0.2087 & 0.0112 & 0.1821 \\
\hline \multicolumn{6}{|l|}{ Woodland Vole } \\
\hline Elevation (m) & 0.0051 & 8.93 & 0.0034 & 0.0721 & 0.0721 \\
\hline Moon Phase (\% Illuminated) & 0.8707 & 5.92 & 0.0166 & 0.0458 & 0.1179 \\
\hline Slope $(\%)$ & 0.0202 & 5.87 & 0.0170 & 0.0436 & 0.1615 \\
\hline \multicolumn{6}{|l|}{ Masked shrew } \\
\hline Aspect & -3.2118 & 10.64 & 0.0015 & 0.0763 & 0.0763 \\
\hline Elevation (m) & 0.0135 & 4.3 & 0.0403 & 0.0300 & 0.1063 \\
\hline Moon Phase (\% Illuminated) & 1.8193 & 3.49 & 0.0642 & 0.0238 & 0.1301 \\
\hline Canopy Cover $>6-12$ m (\%) & -0.0432 & 2.7 & 0.1032 & 0.0181 & 0.1482 \\
\hline
\end{tabular}

${ }^{\mathrm{a}}$ Grassland treatment was analyzed separately because vegetation sampling methods differed from shrub/pole, fragmented forest, and intact forest. 
Table 9. Significant variables from logistic regression of species presence/absence data on habitat and environmental variables on MTMVF landscapes in grassland, shrub/pole, fragmented forest, intact forest treatments on MTMVF landscapes in southern West Virginia.

\begin{tabular}{|c|c|c|c|}
\hline Variable & Parameter Estimate & $\mathrm{X}^{2}$ & $P$ \\
\hline \multicolumn{4}{|l|}{ Grassland Treatment - Sherman Trapping } \\
\hline \multicolumn{4}{|l|}{ House mouse } \\
\hline Distance to Edge (m) & -0.04 & 2.71 & 0.0994 \\
\hline Bare ground $(\%)$ & 15.91 & 3.77 & 0.0520 \\
\hline Hosmer-Lemeshow Goodness-of-Fit ${ }^{\mathrm{a}}$ & & 6.64 & 0.3553 \\
\hline \multicolumn{4}{|l|}{ Grassland Treatment - Array Trapping } \\
\hline \multicolumn{4}{|l|}{ Meadow vole } \\
\hline \multicolumn{4}{|l|}{ Smoky shrew } \\
\hline Aspect & -10.89 & 4.68 & 0.0306 \\
\hline Hosmer-Lemeshow Goodness-of-Fit & & 0.01 & 0.9410 \\
\hline \multicolumn{4}{|l|}{ Pygmy shrew } \\
\hline \multicolumn{4}{|l|}{ No Variables Significant } \\
\hline \multicolumn{4}{|c|}{ Fragmented Forest and Intact Forest Treatments - Sherman Trapping } \\
\hline $\begin{array}{l}\text { Northern short-tailed shrew } \\
\text { No Variables Significant }\end{array}$ & & & \\
\hline \multicolumn{4}{|l|}{ Woodland jumping mouse } \\
\hline Moon Phase (\% Illuminated) & -3.11 & 5.93 & 0.0149 \\
\hline Canopy Height (m) & -0.23 & 4.48 & 0.0343 \\
\hline Hosmer-Lemeshow Goodness-of-Fit & & 8.64 & 0.3737 \\
\hline \multicolumn{4}{|l|}{ Eastern chipmunk } \\
\hline Bare ground (\%) & 19.29 & 5.52 & 0.0188 \\
\hline Moss $(\%)$ & -10.76 & 4.36 & 0.0368 \\
\hline Water $(\%)$ & -30.63 & 7.57 & 0.0059 \\
\hline Stem Density $>38 \mathrm{~cm} \mathrm{DBH}$ & 0.10 & 3.99 & 0.0459 \\
\hline Hosmer-Lemeshow Goodness-of-Fit & & 10.88 & 0.1437 \\
\hline \multicolumn{4}{|c|}{ Fragmented Forest and Intact Forest Treatments - Array Trapping } \\
\hline \multicolumn{4}{|c|}{ Northern short-tailed shrew } \\
\hline Canopy Cover $>12$ m (\%) & -0.03 & 5.27 & 0.0217 \\
\hline Moon Phase (\% Illuminated) & 8.47 & 6.59 & 0.0102 \\
\hline Light Index & -9.34 & 4.64 & 0.0312 \\
\hline Precipitation $(\mathrm{cm})$ & 1.39 & 2.72 & 0.0989 \\
\hline Hosmer-Lemeshow Goodness-of-Fit & & 5.83 & 0.6668 \\
\hline \multicolumn{4}{|l|}{ Woodland jumping mouse } \\
\hline Canopy Cover $>12$ m (\%) & -0.06 & 11.41 & 0.0007 \\
\hline Hosmer-Lemeshow Goodness-of-Fit & & 4.11 & 0.3910 \\
\hline \multicolumn{4}{|l|}{ Pygmy shrew } \\
\hline Water $(\%)$ & 7.45 & 4.11 & 0.0425 \\
\hline Hosmer-Lemeshow Goodness-of-Fit & & 0.99 & 0.3207 \\
\hline \multicolumn{4}{|l|}{ Smoky shrew } \\
\hline Low Temperature $\left({ }^{\circ} \mathrm{C}\right)$ & 0.24 & 5.18 & 0.0228 \\
\hline Hosmer-Lemeshow Goodness-of-Fit & & 10.56 & 0.4807 \\
\hline
\end{tabular}


Table 9. Continued.

\begin{tabular}{llll} 
Variable & Parameter Estimate & $\mathrm{X}^{2}$ & $P$ \\
\hline
\end{tabular}

Shrub/pole, Fragmented Forest, and Intact Forest Treatments - Sherman Trapping

Northern short-tailed shrew

$\begin{array}{lrrr}\text { Bare ground (\%) } & 4.36 & 4.29 & 0.0383 \\ \text { Hosmer-Lemeshow Goodness-of-Fit } & & 1.23 & 0.8729 \\ \text { Woodland jumping mouse } & & & \\ \text { Moon Phase (\% Illuminated) } & -2.81 & 5.28 & 0.0216 \\ \text { Water (\%) } & 7.84 & 4.08 & 0.0434 \\ \text { Canopy Cover }>0.5-3 \text { m (\%) } & 8.33 & 3.63 & 0.0569 \\ \text { Hosmer-Lemeshow Goodness-of-Fit } & & 8.54 & 0.3829 \\ \text { Eastern chipmunk } & -22.14 & & \\ \text { Water (\%) } & 8.92 & 5.86 & 0.0027 \\ \text { Bare ground (\%) } & 6.25 & 5.60 & 0.0179 \\ \text { Canopy cover }>12 \text { m (\%) } & 0.01 & 8.38 & 0.0038 \\ \text { Stem Density >8-38 cm } & & 32.84 & <0.0001\end{array}$

$\underline{\text { Shrub/pole, Fragmented Forest, and Intact Forest Treatments - Array Trapping }}$

Northern short-tailed shrew

Moss (\%)

$\begin{array}{lll}-3.42 & 3.51 & 0.0609\end{array}$

Canopy Cover 3-6 m (\%)

$\begin{array}{lll}0.02 & 2.72 & 0.0992\end{array}$

Precipitation $(\mathrm{cm})$

$\begin{array}{lll}0.91 \quad 3.73 & 0.0533\end{array}$

Hosmer-Lemeshow Goodness-of-Fit

$8.68 \quad 0.3700$

Woodland jumping mouse

Stem Density $\geq 38 \mathrm{~cm} \mathrm{DBH}$

$\begin{array}{lll}1.16 & 7.20 & 0.0073\end{array}$

Stem Density $<8 \mathrm{~cm}$ DBH

$\begin{array}{lll}-0.06 & 9.53 & 0.0020\end{array}$

Hosmer-Lemeshow Goodness-of-Fit

$\begin{array}{ll}4.26 & 0.7492\end{array}$

Pygmy shrew

Canopy Cover 0.5-3 m (\%)

$\begin{array}{lll}0.05 & 8.20 & 0.0042\end{array}$

Hosmer-Lemeshow Goodness-of-Fit

3.910 .5618

Smoky shrew

Low Temperature $\left({ }^{\circ} \mathrm{C}\right)$

0.15

$\begin{array}{ll}4.37 & 0.0366\end{array}$

Hosmer-Lemeshow Goodness-of-Fit

$13.36 \quad 0.2704$

${ }^{a}$ The Hosmer-Lemeshow Goodness-of-Fit statistic tests the null hypothesis that data fit the model; this hypothesis is rejected at $P<0.05$. Higher values indicate a better model fit. 
Table 10. Species captured and method of capture from 1999-2001 in grassland, shrub/pole, fragmented forest, and intact forest treatments on MTMVF landscapes in southern West Virginia.

\begin{tabular}{|c|c|c|c|c|}
\hline & \multicolumn{4}{|c|}{ Treatment } \\
\hline & Grassland & Shrub/Pole & Fragmented Forest & Intact Forest \\
\hline \multicolumn{5}{|l|}{ Order Insectivora } \\
\hline$\overline{\text { Masked shrew }}$ & $\mathrm{D}^{\mathrm{a}}$ & D & B & B \\
\hline Northern short-tailed shrew & $\mathrm{B}$ & $\mathrm{D}$ & $\mathrm{B}$ & $\mathrm{B}$ \\
\hline Pygmy shrew & $\mathrm{D}$ & $\mathrm{D}$ & $\mathrm{D}$ & $\mathrm{D}$ \\
\hline Smoky shrew & $\mathrm{D}$ & $\mathrm{D}$ & $\mathrm{D}$ & $\mathrm{D}$ \\
\hline \multicolumn{5}{|l|}{ Order Rodentia } \\
\hline Allegheny woodrat & $\mathrm{X}$ & $\mathrm{S}$ & $\mathrm{X}$ & $\mathrm{X}$ \\
\hline Eastern chipmunk & $\mathrm{S}$ & $\mathrm{X}$ & $\mathrm{S}$ & $\mathrm{B}$ \\
\hline House mouse & $\mathrm{B}$ & $\mathrm{X}$ & $X$ & $X$ \\
\hline Meadow vole & $\mathrm{B}$ & $\mathrm{B}$ & $\mathrm{D}$ & $\mathrm{D}$ \\
\hline Peromyscus species & B & B & B & B \\
\hline Southern bog lemming & $\mathrm{B}$ & $\mathrm{B}$ & $\mathrm{D}$ & \\
\hline Woodland jumping mouse & $\mathrm{D}$ & $\mathrm{D}$ & $\mathrm{B}$ & $\mathrm{B}$ \\
\hline Woodland vole & $\mathrm{D}$ & $\mathrm{D}$ & $\mathrm{D}$ & $\mathrm{B}$ \\
\hline \multicolumn{5}{|l|}{ Other } \\
\hline 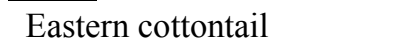 & S & $X$ & $X$ & $\mathrm{X}$ \\
\hline Virginia opossum & S & $\mathrm{X}$ & $\mathrm{B}$ & $\mathrm{X}$ \\
\hline
\end{tabular}




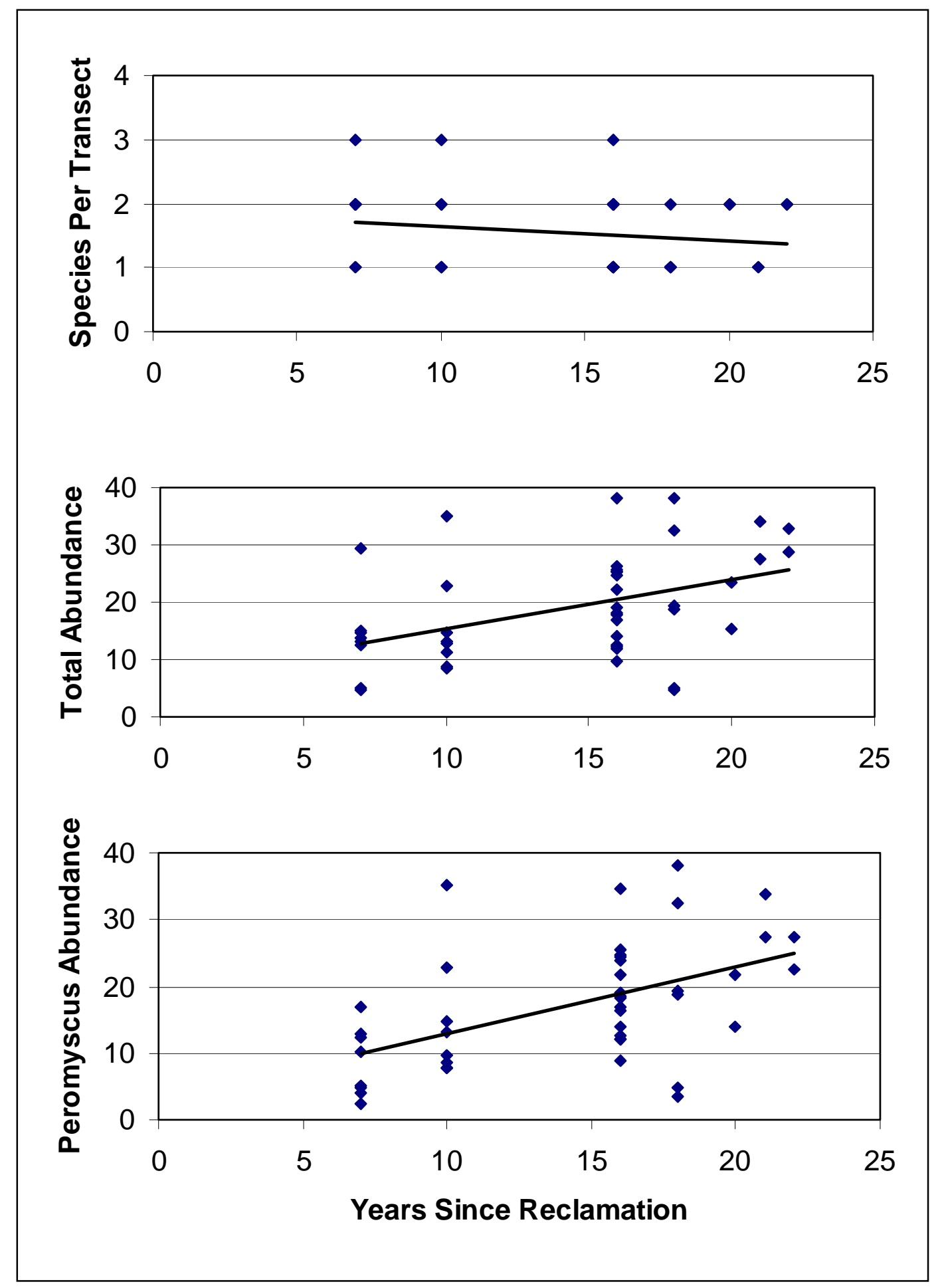

Figure 1. Species richness (\# species per transect), total small mammal abundance $(\# / 100$ trap nights), and Peromyscus abundance (\#/100 trap nights) plotted against years since reclamation at each reclaimed site (grassland or shrub/pole treatment) where Sherman trapping took place on MTMVF landscapes in southern West Virginia. Abundance values from 2 trapping sessions are plotted separately. 

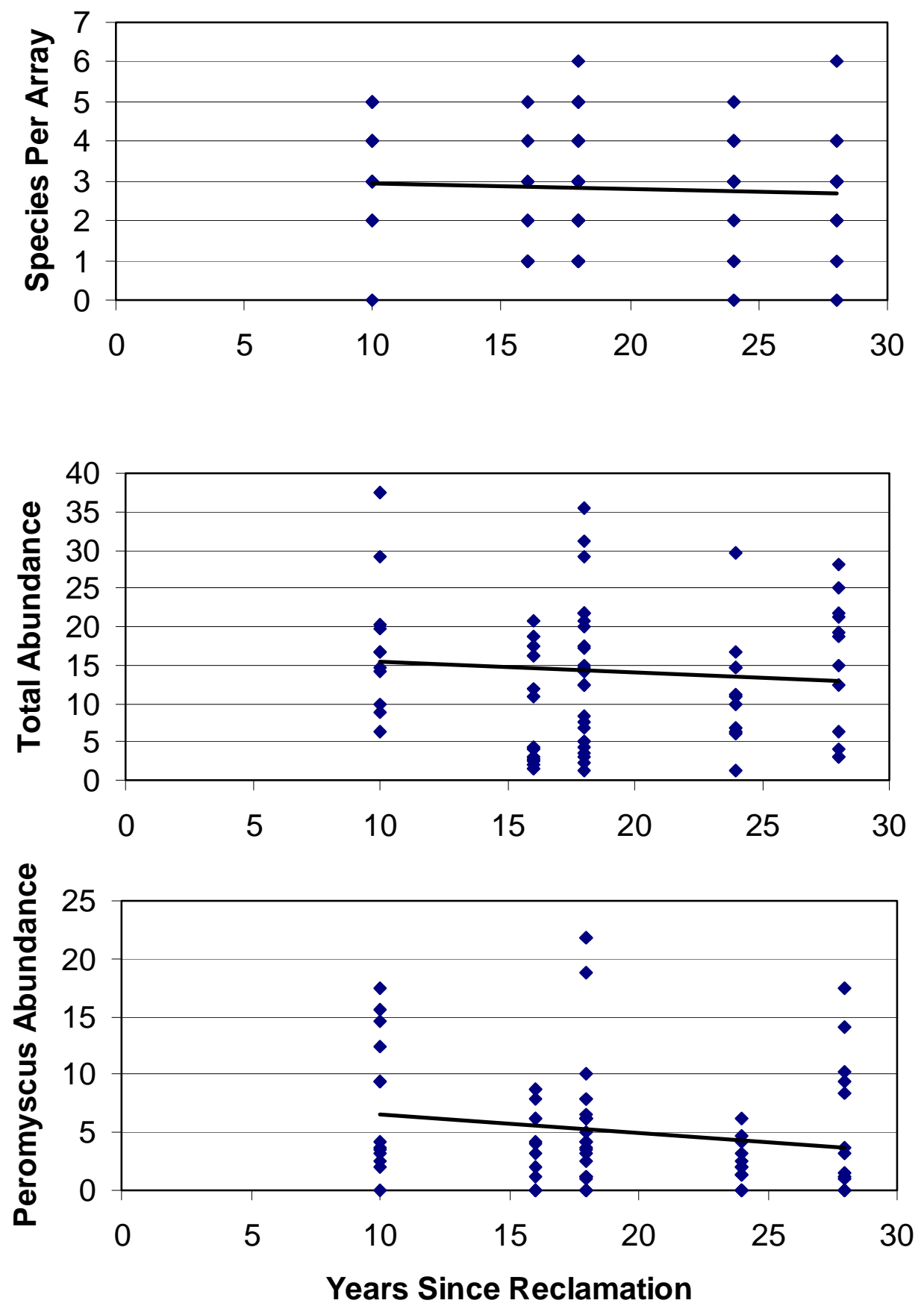

Figure 2. Species richness (\# species per transect), total small mammal abundance (\#/100 trap nights), and Peromyscus abundance (\#/100 trap nights) plotted against years since reclamation at each reclaimed site (grassland or shrub/pole treatment) where drift fence array trapping took place on MTMVF landscapes in southern West Virginia. Abundance values from 13 trapping sessions are plotted separately. 


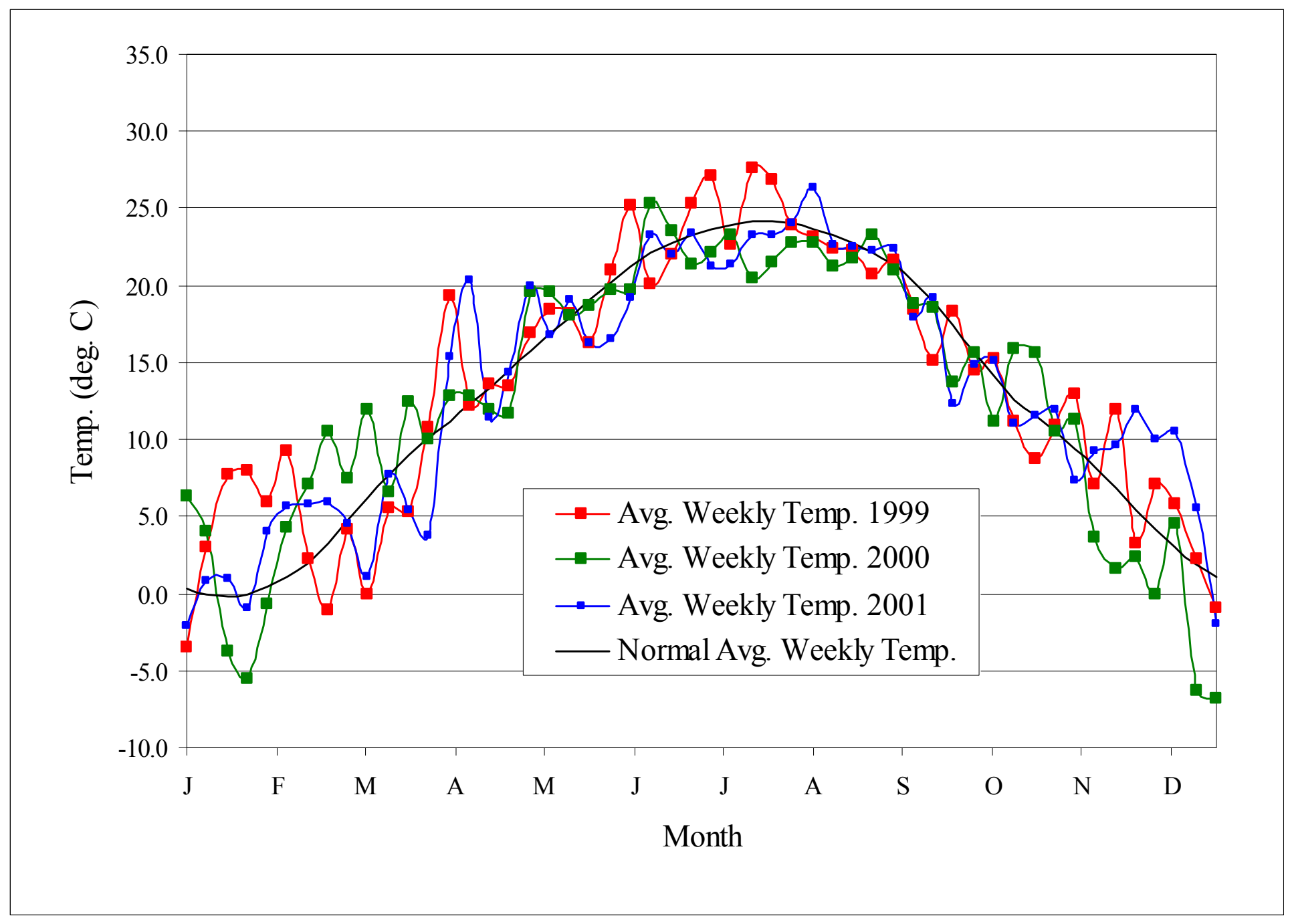

Figure 3. Average weekly temperatures recorded in Charleston, West Virginia in 1999, 2000, and 2001 as compared to 30 -year normals (NOAA/NWS). 


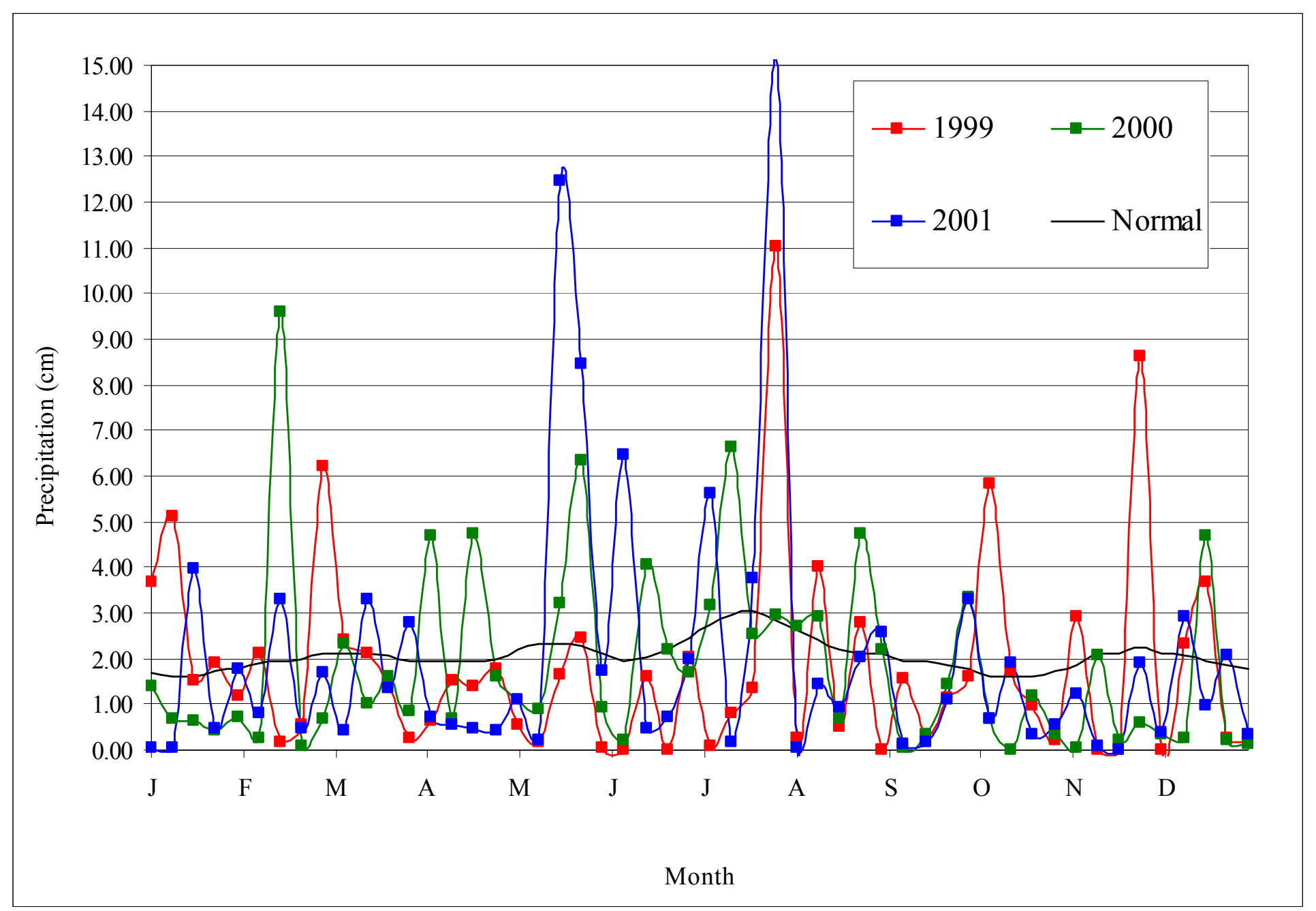

Figure 4. Weekly precipitation reported in Charleston, West Virginia in 1999, 2000, and 2001 as compared to 30-year normals (NOAA/NWS). 


\title{
CHAPTER 3 - USE OF DRAINAGE CHANNELS BY ALLEGHENY WOODRATS ON A RECLAIMED MOUNTAINTOP MINE LANDSCAPE IN SOUTHERN WEST VIRGINIA
}

\begin{abstract}
Allegheny woodrats (Neotoma magister) typically occupy rock outcrops and cliffs within forested habitats. They were captured in reclaimed drainage channels on mountaintop mine/valley fill (MTMVF) landscapes in southern West Virginia with Tomahawk live traps in 2000 and 2001. I sampled 24 sites on 2 mountaintop mine complexes, collected habitat data at each site, and used logistic regression to identify habitat variables related to woodrat presence. During 187 trap nights, 13 adult, 2 subadult, and 8 juvenile woodrats were captured at 13 of the 24 sites. Percent of rock as a groundcover and density of stems $>15 \mathrm{~cm}$ diameter-at-breastheight $(\mathrm{DBH})$ were significantly related to woodrat presence and were significantly greater at sites where woodrats were present than absent. Sites where woodrats were present differed substantially from other described habitats in West Virginia, though they may simulate boulder piles that occur naturally. This study suggests the need for additional research to examine the dynamics between woodrat populations inhabiting rock outcrops in forests adjacent to mines and populations inhabiting constructed drainage channels on reclaimed mines.
\end{abstract}

\section{INTRODUCTION}

The Allegheny woodrat (Neotoma magister) is a medium-sized rodent, resembling a large white-footed mouse with grayish-brown dorsal pelage, white underparts, and a fur-covered tail (Hall 1985, Whitaker and Hamilton 1998). It was considered a subspecies of the Eastern woodrat (Neotoma floridana) until gaining species status based on genetic and morphological characteristics within the last 10 years (Hayes and Harrison 1992, Hayes and Richmond 1993, 
Planz et al. 1996). Its preferred habitat is rock outcrops, limestone caves, cliffs, talus slopes, and boulder piles (Rhoads 1894, Newcombe 1930, Poole 1940, Pearson 1952, Hall 1981). Allegheny woodrats have historically ranged along the Appalachian Mountains from southern New York to northern Alabama and west into Kentucky, Ohio, and Indiana (Hall 1985, Balcom and Yahner 1996). Today, the species is no longer found in New York, has experienced drastic declines in New Jersey and eastern Pennsylvania, and is listed as threatened, endangered, or as a species of special concern in Indiana, Maryland, New Jersey, New York, North Carolina, Ohio, Pennsylvania, Virginia, and West Virginia (Hicks 1989, Kirkland and Krim 1990, Beans 1992, Castleberry 2000b). Population declines have been most precipitous at the northern and western edges of its range; West Virginia, at the center of its geographical distribution, appears to be a stronghold with fairly stable populations, although the official status of woodrats in West Virginia is unknown as surveys statewide have not been conducted (Mengak 1996, Stihler and Wallace 1996). The reason for the woodrat's decline is uncertain, but may be due to exposure to the ascarid roundworm (Baylisascaris procyonis) carried by raccoons (Procyon lotor) (Castleberry 2000b), increased predation due to habitat fragmentation (Balcom and Yahner 1996), or decrease in available hard mast due to the chestnut blight (Cryphonectria parasitica), gypsy moth (Lymantria dispar) defoliation, and the decline in oak (Quercus spp.) abundance (Castleberry 2000b).

In West Virginia, surface coal mining is a major cause of fragmentation to the forested landscape, especially in the southern part of the state where mountaintop mine/valley fill (MTMVF) is a common practice. These large-scale mines extend for several kilometers along ridgelines, and, after reclamation, leave a landscape of grasslands, shrub/pole stands, and narrow strips of forest along bottomland streams. During the mining process, excess spoil is placed into 
the headwaters of streams adjacent to a mined ridgeline, bulldozed into terraces to stabilize the hillside, and fixed with a rock drainage channel down the center to prevent stormwater runoff from washing away the soil (Greene and Raney 1979, Nieman and Merkin 1995).

While conducting a study on small mammals on the MTMVF landscape (see Chapter 2), I captured woodrats in Sherman live traps $(7.7 \times 7.7 \times 9.0 \mathrm{~cm})$ along a rock drainage channel in an area that had been reclaimed approximately 27 years earlier. The channel was characterized by large, loosely-piled boulders shaded by a few trees along the channel edge. Because this was an unusual habitat for woodrats, I decided to expand trapping effort to target woodrats in similar drainage channels. My study objectives were to determine 1) the extent of woodrat distribution on mined landscapes and 2) what specific characteristics of a drainage channel were related to woodrat presence.

\section{STUDY AREA}

Study areas were located on 2 MTMVF complexes in southern West Virginia: the Hobet 21 mine (2431 ha) in the Mud River watershed in Boone County (about $40 \mathrm{~km}$ southwest of Charleston) and the Cannelton mine (2180 ha) in the Twenty-mile Creek watershed on the border of Kanawha and Fayette Counties (about $50 \mathrm{~km}$ southeast of Charleston). Elevation on Hobet 21 averaged $330 \mathrm{~m}(241-423 \mathrm{~m})$, while Cannelton averaged $434 \mathrm{~m}$ (332-566 m).

Drainage channels sampled were located in areas reclaimed 13-27 years prior to our study. A variety of small trees and shrubs, both introduced and native (Table 1), growing within the channel or along the edge of it dominated these areas. Red maple, black locust, and princesstree were the most common trees, while blackberry/raspberry, multiflora rose, and sourwood were common shrub/sapling species. Grasses, such as tall fescue (Festuca arundinacea), and forbs, such as goldenrod (Solidago spp.), also were present. 


\section{METHODS}

\section{Woodrat Trapping}

Reclaimed land on each mine complex consisted of former MTMVF mines as well as old contour mines. I chose 24 drainage channel sites (10 on Hobet and 14 on Cannelton) characterized by large boulders and some canopy cover without regard for mining method used to create the channels because my objective was to locate drainage channels inhabited by Allegheny woodrats on the reclaimed-mine landscape and not to compare mining methods. Tomahawk live traps (Tomahawk Live Trap, Tomahawk, Wisconsin) were baited with apples and placed beneath overhanging rocks in the channel to protect captured animals from rainfall or extreme temperatures. Trapping was conducted for 2 consecutive nights from July 3-28 and September 15-20, 2000, with 2-10 traps placed at each drainage channel site. Because woodrats are relatively easy to capture (Johnson and Madej 1993, Myers 1997), this level of trapping effort was adequate to determine the presence/absence of woodrats.

Captured Allegheny woodrats were ear-tagged, weighed, sexed, examined to determine reproductive status, and aged based on weight. Animals were classified as juvenile if they weighed less than $175 \mathrm{~g}$, as subadults between $\geq 175-225 \mathrm{~g}$, and as adults if weight was $\geq 225 \mathrm{~g}$ (Castleberry 2000b).

\section{Habitat Data Collection}

Vegetation and habitat variables were collected at 1-2 subplots on each channel using sampling methods modified from James and Shugart (1970) and Martin et al. (1997). Subplots were placed at 50-m-intervals along drainage channels, so that the effective sampling area would be adequately described. A 0.04-ha circle was established at each subplot by laying out $222.6-\mathrm{m}$ ropes perpendicular to each other and crossing at the center of the rock channel. Within this 
circle, individual trees were identified and placed into 1 of 3 categories based on diameter-atbreast-height (DBH): $>8-15 \mathrm{~cm},>15-30 \mathrm{~cm}$, and $>30 \mathrm{~cm}$. Shrub, sapling, and pole stems were counted within a 1-m-wide transect along each rope (James and Shugart 1970). Shrub was defined as any woody stem $<3 \mathrm{~cm}$ DBH and $<2 \mathrm{~m}$ in height, and sapling included woody stems $<3 \mathrm{~cm} \mathrm{DBH}$ and $>2 \mathrm{~m}$ in height. Pole trees were 3-8 cm DBH and $>2 \mathrm{~m}$ in height. Percent ground cover and canopy cover above 0.5 -m high were estimated using an ocular sighting tube (James and Shugart 1970) by sighting at the ground and upward at the canopy at 2.3-m intervals along each rope. Ground cover was recorded as green (includes ferns, forbs, and moss), leaf litter, shrub, brier (includes Rubus spp. and Smilax spp.), downed woody debris, rock, bare ground, water, or sericea.

To characterize rock structure in each channel, visual estimates were made of the depth to channel floor and the 3-dimensional size of rocks whenever rock groundcover was present. Approximate volume for each rock tallied was calculated as the product of width, length, and height and used as an indicator of the relative amount of interstitial habitat between rocks. Aspect, slope, canopy height (visual estimate), and drainage width (measured in m) were recorded at each plot. A GPS unit was used to record location of each trapping station, and ArcView 3.2 was used to measure distance to the nearest forest edge and elevation. In addition, each site was given a classification code according to a system developed by the Pennsylvania Game Commission (1996) for the qualitative evaluation of Allegheny woodrat habitat. These codes consist of a 3-digit number, where the first number is habitat type, the second number is relative depth of interstitial spaces, and the third number is the size class of rocks. 


\section{Statistical Analyses}

Microhabitat variables were used to assess differences between occupied and unoccupied sites; drainage channels in which 1 or more Allegheny woodrats were captured were considered occupied. Prior to statistical analyses involving microhabitat variables, arcsine-square root transformations were performed on percentage variables (ground cover and canopy cover) to improve normality (Zar 1999). Aspect, recorded as the direction of flow in each channel as an azimuth from $0^{\circ}$ to $360^{\circ}$, was transformed by the function $(\cos [45-\mathrm{x}]+1)$ to make it an independent variable (Beers et al. 1966). Transformed aspect values correspond to moisture levels on a scale of 0 (southwestern exposure, xeric conditions) to 2 (northeastern exposure, mesic conditions) (Beers et al. 1966). Summary statistics (N, mean, standard error) were calculated for sites where woodrats were present and absent, and means were compared using a two-sample $t$-test (Zar 1999). Results of $t$-tests were considered significant at $P<0.05$.

Stepwise logistic regression was used to identify correlative habitat variables for woodrat presence/absence. Stepwise logistic regression sequentially adds independent (habitat) variables into a predictive model for the dependent variable (woodrat presence/absence), using the Wald $\mathrm{X}^{2}$ statistic to test the contribution of each independent variable, which enter the model at $P$ $<0.30$. Combinations of variables are tested using Wilk's $\Lambda$ likelihood ratio test until it identifies the strongest model. Independent variables stay in the model if, after all combinations are tested, the Wald $\mathrm{X}^{2}$ statistic has $P<0.10$. Finally, the Hosmer-Lemeshow Goodness-of-Fit $\mathrm{X}^{2}$ statistic tests the null hypothesis that the data fit the model, so a $P$-value $<0.05$ indicates that the data do not fit the model (Cody and Smith 1997). Higher values of this statistic suggest a better model fit to the data. Woodrat presence/absence was the dependent variable in the regression model and habitat characteristics were the independent variables. Aspect, elevation, distance to nearest 
forest edge, canopy height, percent canopy cover, channel width, channel depth, rock volume, percent groundcover categories (green, leaf litter, shrub, brier, woody debris, rock, bare ground, water, and sericea), number of shrub and sapling stems (combined), number of pole stems, number of tree stems $>8-15 \mathrm{~cm} \mathrm{DBH}$, and number of tree stems $>15 \mathrm{~cm} \mathrm{DBH}$ were tested in the model. All statistical analyses were completed with the Statistical Analysis System (SAS Version 8, SAS Institute, Inc. 1998).

\section{RESULTS}

A total of 23 woodrats were captured during 187 trap nights, of which 13 were adults in reproductive condition (6 males, 7 females), 2 were subadults (both males), and 8 ( 3 males, 5 females) were juveniles. No subadults or juveniles were in reproductive condition. Juvenile woodrats were captured at 4 of 7 sites where adult females were also captured. Six woodrats were captured at 4 of 10 sites on Hobet 21 Mine (100 trap nights) and 17 were captured at 9 of 14 sites on Cannelton Mine (87 trap nights).

Percentage of rock as groundcover $\left(\right.$ Wald $\left.\mathrm{X}^{2}=4.2860, P=0.0384\right)$ and tree stems $>15$ cm DBH (Wald $\mathrm{X}^{2}=2.9914, P=0.0837$ ) were the only variables identified by logistic regression as related to woodrat presence. Woodrats were more likely to be present where rock groundcover and density of trees $>15 \mathrm{~cm}$ DBH were greater. The Hosmer and Lemeshow Goodness-of-Fit test had a $P$-value of 0.6111 , suggesting that the regression model was a good fit to the data. $T$-tests also identified rock groundcover and tree stems $>15 \mathrm{~cm}$ DBH as habitat characteristics that differed between sites with and without woodrats present (Table 2). Both of these variables were significantly greater where woodrats were present.

Reclaimed drainage channels fell into 5 categories (Table 3) using the Pennsylvania Game Commission's classification codes for rocky habitat (1996). The most common 
classification code was 211 , referring to "rock city, large float block" habitat type, with deep interstices, and blocks $>5-10 \mathrm{~m}$ in size. Of 8 sites of this classification, 6 were occupied by woodrats. The next most common code was 122 , which was "talus" habitat, with shallow interstices, and blocks $>1-3 \mathrm{~m}$ in size. Five of 7 sites of this type were occupied by woodrats. Four of 6 sites of type 123 were unoccupied; these differed from 122 in that blocks were $>3-5 \mathrm{~m}$ in size. Two sites — both unoccupied — were code 123, having "talus" habitat, with deep interstices, and rocks $>3-5 \mathrm{~m}$ in size. The last habitat type was code 221 , with "rock city, large float block" habitat, shallow interstices, and blocks $>5-10 \mathrm{~m}$ in size. It accounted for 1 unoccupied site. Overall, there did not appear to be use of any particular habitat type, depth of interstices, or boulder size.

\section{DISCUSSION}

Typical woodrat habitat consists of rock structure, such as outcrops, cliffs, and limestone caves, surrounded by forest (Poole 1940). The presence of woodrats in constructed drainage channels on a MTMVF landscape was unexpected because channels are generally surrounded by large expanses of grasslands or early-successional habitats. Canopy cover at occupied sites averaged 50.2\%, much lower than values reported by Wood (2001) in the New River Gorge National River (NRGNR) in southern West Virginia (80.4\%) and Myers (1997) at Coopers Rock State Forest (CRSF) in north-central West Virginia (71.5\%). Castleberry et al. (2001) found that Allegheny woodrats on the Westvaco Experimental Research Forest (WERF) in Randolph County, West Virginia, occupied rock outcrops adjacent to clearcuts when intact forest was maintained on one side of the outcrop; outcrops completely surrounded by clearcuts were not occupied. Woodrats foraged in the clearcut where canopy cover averaged $17.1 \%$, as well as in the adjacent forest where canopy cover averaged $81.7 \%$, suggesting that they may tolerate a wide 
range of canopy cover. Percentage of canopy cover at the rock outcrop itself was not reported, however.

Tree stems $>15 \mathrm{~cm}$ were more abundant where woodrats were present than absent (Table 2) and were predictive of woodrat presence. Trees may improve the channels as woodrat habitat by providing shade in the summer or thermal cover in the winter, as well as a food source. Many of the tree species present in channels provide seeds, fruit, or green vegetation eaten by woodrats (Table 1; Martin et al. 1951, Castleberry 2000a). Species bearing hard mast, an important food source for woodrats (Wagel and Feldhammer 1997, Castleberry 2000a), were virtually absent and those that were present were generally not mature enough to produce mast. The density of tree stems $>15 \mathrm{~cm}$ DBH per 0.04 ha plot at occupied MTMVF drainage channels (6.3) was considerably lower than the value reported by Myer $(16.3 ; 1997)$ on CRSF. This may reflect the early-successional state of reclaimed MTMVF sites as compared to the mature forests of CRSF. Density of trees $>8 \mathrm{~cm}$ DBH per 0.04-ha plot at occupied drainage sites was compared with values reported by Wood (2000) and Castleberry (2000b) because these studies did not report densities in a $>15 \mathrm{~cm}$ DBH category. On occupied MTMVF channels, there were 14.9 trees $>8$ cm DBH per plot, similar to occupied sites in the NRGNR (16.5; Wood 2000) and at woodrat foraging locations on the WERF (Castleberry 2000b), where means of 8.7 in clearcuts, and 14.9, 19.3, and 21.0 trees per plot at 3 forest treatments were reported. The size distributions may have differed as NRGNR and intact forest treatments at the WERF are likely to have had more trees $>15 \mathrm{~cm}$ DBH than clearcuts at the WERF and early-successional reclaimed MTMVF sites.

The percent of rock as a groundcover was considerably higher (53.3\%) in occupied drainage channels than values reported by Wood $(19.1 \%, 2001)$ and Myers $(22.0 \%, 1997)$. Rock cover was strongly predictive of woodrat presence in reclaimed areas, suggesting that woodrats 
may key in on this characteristic when searching for areas to colonize. The amount of rock groundcover may have been important at MTMVF sites because it reflects the size of the area covered by channels and is likely to be an indicator of the complexity of interstitial networks and the ability of a site to provide predator protection and den sites. Other characteristics of rock channels were apparently not as important; channel depth, channel width and rock volume were not significantly different between sites where woodrats were present and absent, and they were not identified by logistic regression as significant predictors of woodrat presence. Loosely piled boulders provide an uncountable number of crevices for protective cover and den sites, and may simulate natural boulder piles known to provide woodrat habitat that were formed as rock crumbles from outcrops (Hall 1981). I found no quantitative description of such habitat for comparison with rock channel width, depth, and rock size at mine sites, but reclaimed drainage channels probably resemble this type of habitat more closely than they resemble the natural rock outcroppings found at NRGNR, CRSF, and the WERF.

Classification of rock channels according to the system developed by the Pennsylvania Game Commission (1997) did not suggest an association between qualitative codes and woodrat presence (Table 3). Myers (1997) used a modified version of this system and found that, despite talus rock structure being relatively scarce at CRSF ( $2.1 \%$ of sampling units), the percentage of talus sites occupied ( 2 of 7 sites, $28.7 \%$ ) was comparable to the percentage at rock outcroppings with numerous overhangs, crevices, and caves (26 of 82 sites, $31.7 \%$ ). He speculated that talus sites, with rocks $<5 \mathrm{~m}$, still provided adequate interstitial space for woodrat occupation. His sites classified as "rock city, large float block," in contrast, were rarely occupied (1 of 66 sites, 1.5\%), possibly because large float blocks did not create as complex a network of interstices as talus sites. All of the rock channels on the MTMVF sites fell into either the "talus" or the "large float, 
block, rock city" category, and the trend found by Myers was not present. The reason may be that MTMVF drainage channels classified as "rock city, large float block" generally contained smaller rocks as well as the dominant large boulders. Rocks in the 1-3 m size range were numerous, possibly providing interstitial complexity comparable to Myers' talus sites.

\section{Conclusions and Recommendations}

Habitat fragmentation has been suggested as one of the causes of woodrat declines through the spread of disease, the increase in predator populations, and the improved predator access to woodrat colonies. Though my trapping effort was not sufficient to assess the local abundance of woodrats, presence of reproductive females and juveniles suggests that rock channels may provide adequate breeding habitat within a highly disturbed landscape. I captured adults in reproductive condition and juveniles at the same sites, further suggesting that juveniles were not simply dispersers from other areas, but were produced at those sites. Castleberry et al. (2002), conducting studies on a landscape fragmented by timber harvest in West Virginia, found that Allegheny woodrats were able to tolerate a wide range of macrohabitat conditions if microhabitat conditions were acceptable. Further study is needed to determine the health of woodrat populations on mountaintop mines and their relation with populations in nearby natural rock structure. It is not known whether drainage channels act as viable subpopulations in a metapopulation or as sinks colonized by an overflow of individuals from adjacent forested lands (Hanski 1996, Pulliam 1988, 1996).

A more intensive, long-term study is warranted, especially given the tenuous status of the Allegheny woodrat. I recorded distances from rock channels to the nearest forest habitat and found no difference between occupied and unoccupied sites, but I did not sample for woodrats in nearby forests. Additional trapping at rock outcrops in forests adjacent to mines may be 
instructive in our understanding of woodrat presence at drainage channels because proximity to active colonies may affect recruitment rates on reclaimed mines. Further trapping on mine complexes should compare different ages of reclaimed channels to determine the amount of time it takes for a newly reclaimed rock drainage to develop a great enough stem density to become suitable for use. A study combining trapping on mines and adjacent forests, radio-tracking of woodrat movement between the two, and mitochondrial DNA analysis to determine the history of their movement among subpopulations would perhaps provide information leading to improved management strategies for this species. 
Table 1. Shrub and tree species found at 24 reclaimed drainage channels trapped for Allegheny woodrats on MTMVF landscape in southern West Virginia and their potential food value to woodrats.

\begin{tabular}{|c|c|c|c|c|c|c|c|}
\hline \multirow[b]{2}{*}{ Common Name } & \multirow[b]{2}{*}{ Scientific Name } & & \multirow[b]{2}{*}{ \# Sites } & \multicolumn{4}{|c|}{ Size Class (DBH) } \\
\hline & & & & $<3 \mathrm{~cm}$ & $\geq 3-8 \mathrm{~cm}$ & $>8-15 \mathrm{~cm}$ & $>15 \mathrm{~cm}$ \\
\hline \multicolumn{8}{|l|}{ Fruit/Soft Mast } \\
\hline Tree of heaven & Ailanthus altissima & & 9 & 35 & 14 & 12 & 11 \\
\hline Flowering dogwood & Cornus florida & $*$ & 2 & 1 & 1 & 0 & 0 \\
\hline Autumn olive & Elaeagnus umbellata & $* *$ & 5 & 12 & 1 & 0 & 0 \\
\hline Princess-tree & Paulownia tomentosa & & 13 & 7 & 9 & 19 & 29 \\
\hline Pin cherry & Prunus pennsylvanica & $* *$ & 3 & 4 & 0 & 0 & 0 \\
\hline Black cherry & Prunus serotina & $* *$ & 3 & 1 & 0 & 4 & 0 \\
\hline Winged sumac & Rhus copallinum & $*$ & 1 & 3 & 0 & 0 & 0 \\
\hline Staghorn sumac & Rhus typhina & $*$ & 7 & 34 & 6 & 7 & 0 \\
\hline Multiflora rose & Rosa multiflora & $*$ & 9 & 271 & 0 & 0 & 0 \\
\hline Blackberry/raspberry & Rubus spp. & $* *$ & 22 & 735 & 0 & 0 & 0 \\
\hline Blue elderberry & Sambucus cerulea & $*$ & 1 & 4 & 0 & 0 & 0 \\
\hline Blueberry & Vaccinium spp. & $* *$ & 1 & 3 & 0 & 0 & 0 \\
\hline Grape vine & Vitis spp. & & 7 & 63 & 0 & 0 & 0 \\
\hline \multicolumn{8}{|l|}{ Seeds/Hard Mast } \\
\hline$\overline{\text { Box elder }}$ & Acer negundo & $* *$ & 4 & 3 & 1 & 4 & 3 \\
\hline Red maple & Acer rubrum & $* *$ & 17 & 66 & 16 & 20 & 0 \\
\hline Sugar maple & Acer saccharum & $* *$ & 5 & 0 & 0 & 1 & 3 \\
\hline Yellow birch & Betula allegheniensis & $*$ & 1 & 0 & 0 & 1 & 0 \\
\hline Black birch & Betula lenta & $*$ & 8 & 33 & 35 & 25 & 13 \\
\hline American beech & Fagus grandifolia & $*$ & 1 & 1 & 1 & 1 & 0 \\
\hline White ash & Fraxinus americana & & 4 & 7 & 1 & 0 & 0 \\
\hline Green ash & Fraxinus pennsylvanica & & 1 & 1 & 0 & 0 & 0 \\
\hline Bicolor lespedeza & Lespedeza bicolor & & 3 & 12 & 0 & 0 & 0 \\
\hline Yellow-poplar & Liriodendron tulipifera & & 10 & 4 & 4 & 12 & 11 \\
\hline Pine spp. & Pinus spp. & $* *$ & 2 & 0 & 0 & 3 & 2 \\
\hline American sycamore & Platanus occidentalis & $* *$ & 10 & 5 & 2 & 8 & 4 \\
\hline Black locust & Robinia pseudoacacia & & 22 & 55 & 27 & 85 & 38 \\
\hline Sassafras & Sassafras albidum & & 1 & 2 & 1 & 1 & 0 \\
\hline American basswood & Tilia americana & & 1 & 0 & 0 & 1 & 0 \\
\hline \multicolumn{8}{|c|}{ Bark or Green Vegetation } \\
\hline Eastern redbud & Cercis canadensis & & 3 & 4 & 0 & 0 & 0 \\
\hline Sourwood & Oxydendrum arboreum & & 9 & 26 & 15 & 5 & 0 \\
\hline Willow species & Salix spp. & & 2 & 13 & 0 & 5 & 3 \\
\hline Bigtooth aspen & Populus grandidentata & & 3 & 4 & 2 & 1 & 6 \\
\hline Eastern hemlock & Tsuga canadensis & $* *$ & 1 & 0 & 0 & 1 & 0 \\
\hline \multicolumn{8}{|l|}{ Non-food } \\
\hline Snag & & & 17 & 88 & 8 & 49 & 13 \\
\hline
\end{tabular}

${ }^{a}$ Species followed by a single asterisk $\left({ }^{*}\right)$ have been identified as food sources for Neotoma spp. in other studies; two asterisks indicate that the species has been identified as a relatively important food source (Martin et al. 1951, Castleberry 2000a). 
Table 2. $T$-test comparison of means of habitat variables at 13 rock drainage channel sites where woodrats were present and 11 where they were absent on MTMVF landscapes in southern West Virginia.

\begin{tabular}{|c|c|c|c|c|c|c|c|c|c|c|}
\hline & \multicolumn{4}{|c|}{ Present } & \multicolumn{4}{|c|}{ Absent } & \multicolumn{2}{|c|}{$t$-test results } \\
\hline & Mean & SE & Min & $\operatorname{Max}$ & Mean & SE & Min & Max & $t$-value & $P$ \\
\hline Aspect $\left({ }^{\circ}\right)^{\mathrm{a}}$ & 189.27 & 28.86 & 40.00 & 331.00 & 185.55 & 29.45 & 5.00 & 312.00 & 0.78 & 0.4409 \\
\hline Dist. to Forest Edge (m) & 215.92 & 35.08 & 39.00 & 399.00 & 229.09 & 43.94 & 45.00 & 595.00 & -0.24 & 0.8158 \\
\hline Elevation $(\mathrm{m})$ & 398.85 & 15.46 & 318.00 & 469.00 & 402.36 & 13.03 & 341.00 & 469.00 & -0.17 & 0.8650 \\
\hline Canopy Height (m) & 7.27 & 0.43 & 3.66 & 9.45 & 6.87 & 0.67 & 3.05 & 10.06 & 0.51 & 0.6180 \\
\hline Canopy Cover $(\%)^{\mathrm{b}}$ & 47.88 & 7.59 & 10.00 & 100.00 & 40.45 & 8.14 & 5.00 & 90.00 & 0.8 & 0.4337 \\
\hline Channel Width (m) & 10.44 & 1.02 & 6.00 & 17.00 & 9.91 & 1.60 & 4.00 & 24.00 & 0.29 & 0.7774 \\
\hline Channel Depth (m) & 1.97 & 0.33 & 0.43 & 4.14 & 1.59 & 0.25 & 0.69 & 3.45 & 0.89 & 0.3826 \\
\hline Rock Volume $\left(\mathrm{m}^{3}\right)^{\mathrm{c}}$ & 4.47 & 1.27 & 0.29 & 15.83 & 4.11 & 0.81 & 0.60 & 8.48 & 0.24 & 0.8140 \\
\hline \multicolumn{11}{|l|}{ Ground Cover (\%) } \\
\hline Green & 26.54 & 4.28 & 5.00 & 55.00 & 39.32 & 5.50 & 15.00 & 67.50 & -1.86 & 0.0767 \\
\hline Leaf Litter & 11.15 & 3.41 & 0.00 & 35.00 & 8.41 & 3.82 & 0.00 & 40.00 & 0.59 & 0.5622 \\
\hline Shrub & 3.85 & 1.90 & 0.00 & 20.00 & 6.14 & 3.12 & 0.00 & 35.00 & -0.52 & 0.6099 \\
\hline Brier & 3.46 & 1.40 & 0.00 & 15.00 & 3.18 & 2.14 & 0.00 & 25.00 & 0.42 & 0.6821 \\
\hline Woody Debris & 0.19 & 0.20 & 0.00 & 2.50 & 0.45 & 0.44 & 0.00 & 5.00 & -0.36 & 0.7224 \\
\hline Rock & 49.62 & 5.28 & 5.00 & 70.00 & 30.23 & 4.09 & 10.00 & 55.00 & 2.62 & 0.0157 \\
\hline Bare ground & 1.15 & 0.63 & 0.00 & 5.00 & 1.82 & 0.97 & 0.00 & 10.00 & -0.40 & 0.6912 \\
\hline Water & 1.15 & 1.20 & 0.00 & 15.00 & 0.00 & 0.00 & 0.00 & 0.00 & 1.00 & 0.3370 \\
\hline Sericea & 2.50 & 1.10 & 0.00 & 10.00 & 9.77 & 4.19 & 0.00 & 50.00 & -1.83 & 0.0811 \\
\hline \multicolumn{11}{|l|}{ Stem Densities (no./plot) } \\
\hline$<3 \mathrm{~cm}$ (Shrub and Sapling) & 41.85 & 6.64 & 5.00 & 86.00 & 66.18 & 11.70 & 13.50 & 131.00 & -1.85 & 0.0784 \\
\hline$\geq 3-8 \mathrm{~cm}$ (Pole) & 4.96 & 0.93 & 0.00 & 11.00 & 4.86 & 1.36 & 0.00 & 14.00 & 0.06 & 0.9524 \\
\hline$>8-15 \mathrm{~cm}$ & 8.00 & 1.31 & 1.00 & 17.00 & 9.41 & 2.18 & 0.00 & 28.00 & -0.56 & 0.5785 \\
\hline$>15 \mathrm{~cm}$ & 6.35 & 1.44 & 0.00 & 16.00 & 2.23 & 0.52 & 0.00 & 5.00 & 2.78 & 0.0138 \\
\hline \multicolumn{11}{|l|}{ Species Richness } \\
\hline$<8 \mathrm{~cm} \mathrm{DBH}$ & 6.65 & 0.75 & 3.00 & 11.00 & 6.00 & 0.41 & 4.00 & 8.00 & 0.74 & 0.4668 \\
\hline$\geq 8 \mathrm{~cm} \mathrm{DBH}$ & 4.19 & 0.59 & 2.00 & 9.00 & 3.64 & 0.58 & 1.00 & 8.00 & 0.67 & 0.5100 \\
\hline
\end{tabular}

${ }^{a}$ Beers transformation performed on aspect prior to analysis $(\cos [45-x]+1)$; actual data presented in table.

${ }^{\mathrm{b}}$ Percentage variables were arcsine square root transformed before running $t$-test; actual data presented in table.

${ }^{\mathrm{c}}$ Calculated as the average of the product of the estimated length, width, and height for rocks recorded as groundcover. 
Table 3. Classification of reclaimed drainage channels on MTMVF landscape in southern West Virginia, using codes developed by the Pennsylvania Game Commission (1996) for assessment of Allegheny woodrat habitat.

\begin{tabular}{lllrr}
\hline & & & \\
\cline { 3 - 4 } Habitat Type & Quality of Habitat & Size of rock & Code & Woodrats Present \\
\hline Talus & Bare rock, deep interstices & $>3-5 \mathrm{~m}$ & 113 & 0 \\
Talus & Bare rock, shallow intersices & $>1-3 \mathrm{~m}$ & 122 & 5 \\
Talus & Bare rock, shallow intersices & $>3-5 \mathrm{~m}$ & 123 & 2 \\
Rock city, large float block & Bare rock, deep interstices & $>5-10 \mathrm{~m}$ & 211 & 6 \\
Rock city, large float block & Bare rock, shallow intersices & $>5-10 \mathrm{~m}$ & 221 & 4 \\
\hline
\end{tabular}




\section{CHAPTER 4 - MANAGEMENT IMPLICATIONS}

\section{SMALL MAMMAL COMMUNITIES}

The conversion of forested mountaintops to grassland and shrub/pole habitats by MTMVF operations appears to increase the abundance of the small mammal species for which my methods sampled. Several mammal species or groups of species that are known to occur in the region based on WV GAP analysis data, personal communication by M. E. Hight (mammalogist, Marshall University 2000), and Whitaker and Hamilton (1998) were not sampled by any of the methods used in my study (Table 1). These include moles (Family Talpidae), squirrels (Family Sciuridae), carnivores (Order Carnivora), ungulates (Order Artiodactyla), rabbits (Order Lagomorpha), and bats (Order Chiroptera). These species are equally important components of the mammal community, so management decisions on MTMVF landscapes should be made with their habitat needs in mind as well as those of the small mammals for which my project sampled.

The increase in small mammals in reclaimed areas is driven by Peromyscus spp., which generally thrive in early-successional habitats. Regression analysis determined that the percentage of bare ground in reclaimed areas was strongly negatively related to Peromyscus abundance and total small mammal abundance (Fig. 1). This suggests that ensuring the establishment of groundcover in reclaimed areas may increase small mammal abundance. Current reclamation practices, such as planting grasses and other vegetation to stabilize and restore nitrogen to soil, appear to effectively provide ground cover and forage required by Peromyscus. This layer of vegetation in reclaimed areas may not be beneficial to grassland bird species, however. Studies of grassland birds on reclaimed strip mines (Wray et al. 1982) and 
MTMVF complexes (Ammer and Wood, unpublished data) found a positive relation between bare ground and the density of grasshopper sparrow (Ammodramus savannarun) nests. A management strategy to benefit both small mammals and grassland birds might require planting of complete groundcover in some areas while maintaining patches of bare ground in other areas.

Because small mammal abundance is greater in reclaimed areas, species that prey on mice in open habitats may benefit from MTMVF. For example, northern harriers (Circus cyaneus) and short-eared owls (Asio flammeus), avian predators not typically found in West Virginia, were regularly observed on reclaimed MTMVF complexes during this study (personal observation, Balcerzak 2001). Management of small mammal populations to benefit these species would require maintaining grassland habitats. Although succession to shrub/pole did not change the small mammal community I sampled, and no difference in abundance was found between grassland and shrub/pole treatments, active management of grasslands may be necessary to prevent successional changes that would render sites unsuitable for these avian predators.

Other predators, such as snakes and carnivorous mammals, may benefit from small mammal abundance in reclaimed areas as well. One snake species, the northern black racer (Coluber constrictor), was captured more frequently in shrub/pole treatments than in forests adjacent to MTMVF complexes (Williams and Wood, unpublished data). In addition, red foxes (Vulpes vulpes), gray foxes (Urocyon cinereoargenteus), coyotes (Canis latrans), bobcats (Lynx rufus), and least weasels (Mustela nivalis) are known to feed on small mammals in open habitats (Whitaker and Hamilton 1998). Because these predators are all very secretive, they often are not detected by incidental observation. Unlike the northern harriers and short-eared owls, these mammalian predators are generalist in habitat needs and would probably still be present after reclaimed lands succeed to forest (Whitaker and Hamilton 1998). Additional research to 
determine the effects of MTMVF on these species may be instructive in making management decisions to benefit them. Specifically, I would recommend a study using radio telemetry to determine whether carnivores are using reclaimed land in proportion to its availability.

\section{ALLEGHENY WOODRATS}

The persistence of Allegheny woodrats on landscapes disturbed by MTMVF operations may suggest that woodrats are more adaptable to fragmentation and human disturbance than was once believed. Studies by Castleberry et al. (2000b, 2001, 2002) and Wood (2001) reported similar findings. Castleberry et al. $(2000 \mathrm{~b}, 2001,2002)$ studied Allegheny woodrats on a landscape fragmented by timber harvest and found that they foraged in openings created by clearcuts and occupied rock outctrops adjacent to clearcuts on one side. They concluded that woodrats would occupy a site if microhabitat conditions were suitable, and were fairly tolerant to a variety of macrohabitat or landscape conditions. Wood (2001) found that proximity of a rock outcrop to areas of small-scale human disturbance such as roads or campgrounds was positively related to woodrat occupancy, suggesting that woodrats were able to tolerate some disturbance.

The use of reclaimed drainage channels by Allegheny woodrats does not imply that MTMVF is beneficial to woodrats. Allegheny woodrats typically inhabit natural rock outcrops that are found along ridgelines where erosion due to rain and other elements has worn away topsoil to expose rocks. MTMVF removes ridgelines where rock outcrops occur, and consequently, woodrat colonies are likely to be lost due to MTMVF activities. This loss may be partially mitigated by woodrat occupation of constructed drainage channels on mines, but my study was not designed to determine whether the habitat created adequately replaces - in quantity or quality—-the habitat that is destroyed by MTMVF. Further study is necessary to answer this question and to determine the importance of drainage channel subpopulations to the 
metapopulation of woodrats. In addition, the proximity and connectivity of drainage channels to forests where woodrats occur should be investigated, as these factors are likely to affect recruitment rates and may be important in predicting the presence of woodrats at a given site.

My findings with regard to woodrat occupation of drainage channels suggest that it may be possible to expedite the successional changes that occurred to make drainage channels more suitable for woodrats. The positive relation between the density of tree stems $>15 \mathrm{~cm} \mathrm{DBH}$ and woodrat presence at drainage channels suggests that planting trees during reclamation may improve woodrat habitat. Tree species that can survive the harsh soil conditions should be planted, in particular fast-growing native species such as maples, poplars, and ashes, and fruiting species. Once these species become established, they will provide shade as well as perches for birds. The birds that use these perches, in turn, will help disperse seeds and continue to advance the successional state. Tree species that provide hard mast, such as oaks, are important to woodrats and have not become established at drainage channels. It is unknown whether they would survive in these areas, but it may be beneficial to woodrats and other small mammals, as well as turkey and deer, if planting of oaks is attempted.

Generally, my findings suggest that rocky habitat can be created on mines during reclamation as a way to mitigate loss of natural rock outcrops due to MTMVF activity. Loose boulder piles apparently provide an acceptable alternative for woodrats and may substitute as habitat for other species that are associated with natural rock outcrops. I suggest that boulder fields be created during reclamation. Creating rocky habitat using boulders of different sizes at low, mid, and upper slopes may maximize the number of species that will benefit. 
Table 1. Mammal species expected to occur in southern West Virginia and ability of study methods to detect their presence.

\begin{tabular}{|c|c|c|c|}
\hline \multirow[b]{2}{*}{ Common Name } & \multirow[b]{2}{*}{ Scientific Name } & \multicolumn{2}{|c|}{ Sampling Methods Appropriate to Detect Species? } \\
\hline & & YES & NO \\
\hline \multicolumn{4}{|l|}{ Order Insectivora } \\
\hline Short-tailed shrew & Blarina brevicauda & $\mathrm{X}$ & \\
\hline Hairy-tailed mole & Parascalops breweri & & $\mathrm{X}$ \\
\hline Masked Shrew & Sorex cinereus & $\mathrm{X}$ & \\
\hline Smoky shrew & Sorex fumeus & $\mathrm{X}$ & \\
\hline Pygmy shrew & Sorex hoyi & $\mathrm{X}$ & \\
\hline \multicolumn{4}{|l|}{ Order Rodentia } \\
\hline Beaver & Castor canadensis & & $\mathrm{X}$ \\
\hline Southern red-backed vole & Clethrionomys gapperi & $\mathrm{X}$ & \\
\hline Southern flying squirrel & Glaucomys volans & & $\mathrm{X}$ \\
\hline Groundhog & Marmota monax & & $\mathrm{X}$ \\
\hline Meadow vole & Microtus pennsylvanicus & $\mathrm{X}$ & \\
\hline Woodland vole & Microtus pinetorum & $\mathrm{X}$ & \\
\hline House mouse & Mus musculus & $\mathrm{X}$ & \\
\hline Woodland jumping mouse & Napaeozapus insignis & $\mathrm{X}$ & \\
\hline Allegheny woodrat & Neotoma magister & $\mathrm{X}$ & \\
\hline Golden mouse & Ochrotomys nuttalli & $\mathrm{X}$ & \\
\hline Muskrat & Ondatra zibethicus & & $\mathrm{X}$ \\
\hline Peromyscus spp. & P. leucopus/maniculatus & $\mathrm{X}$ & \\
\hline Eastern gray squirrel & Sciurus carolinensis & & $\mathrm{X}$ \\
\hline Eastern fox squirrel & Sciurus niger & & $\mathrm{X}$ \\
\hline Southern bog lemming & Synaptomys cooperi & $\mathrm{X}$ & \\
\hline Eastern chipmunk & Tamias striatus & $\mathrm{X}$ & \\
\hline Red squirrel & Tamiasciurus hudsonicus & & $\mathrm{X}$ \\
\hline \multicolumn{4}{|l|}{ Order Carnivora } \\
\hline Coyote & Canis latrans & & $\mathrm{X}$ \\
\hline Bobcat & Lynx rufus & & $\mathrm{X}$ \\
\hline Striped skunk & Mephitis mephitis & & $\mathrm{X}$ \\
\hline Long-tailed weasel & Mustela frenata & & $\mathrm{X}$ \\
\hline Least weasel & Mustela nivalis & & $\mathrm{X}$ \\
\hline Mink & Mustela vison & & $\mathrm{X}$ \\
\hline Raccoon & Procyon lotor & & $\mathrm{X}$ \\
\hline Gray fox & Urocyon cinereoargenteus & & $\mathrm{X}$ \\
\hline Black bear & Ursus americanus & & $\mathrm{X}$ \\
\hline Red fox & Vulpes vulpes & & $\mathrm{X}$ \\
\hline \multicolumn{4}{|l|}{ Other } \\
\hline 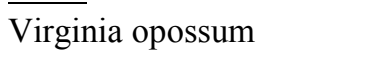 & Didelphis virginiana & & $\mathrm{X}$ \\
\hline White-tailed deer & Odocoileus virginianus & & $\mathrm{X}$ \\
\hline Wild boar & Sus scrofa & & $\mathrm{X}$ \\
\hline Eastern cottontail & Sylvilagus floridanus & & $\mathrm{X}$ \\
\hline
\end{tabular}




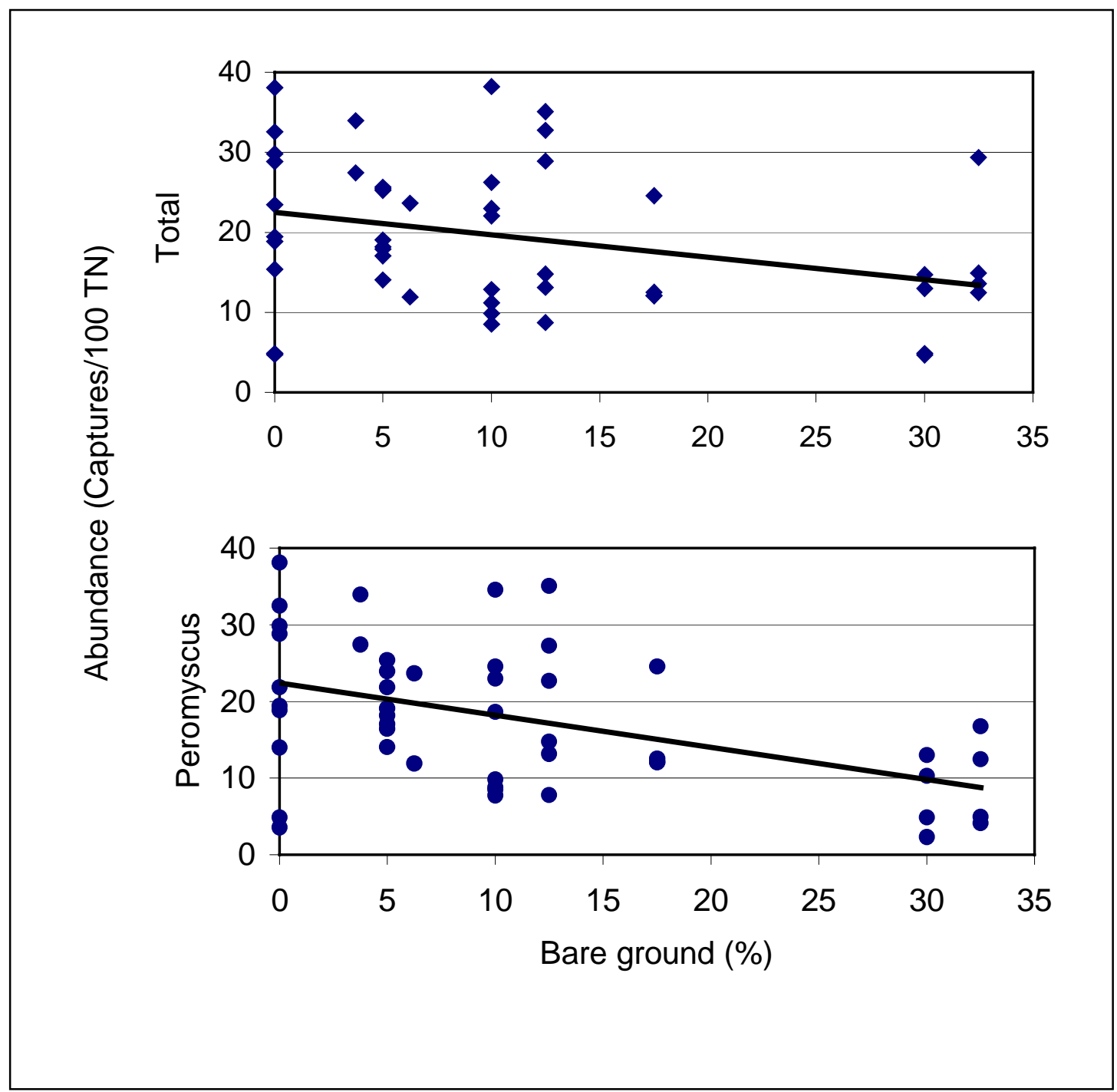

Figure 1. Total small mammal abundance and Peromyscus abundance (\# individuals/100 trap nights) versus percent bare ground for Sherman trapping data. 


\section{LITERATURE CITED}

Adler, G. H., L. M. Reich, and R. H. Tamarin. 1984. Characteristics of white-footed mice in woodland and grassland in eastern Massachusetts. Acta Theriologica 29: 57-62.

Adler, G. H. and M. L. Wilson. 1987. Demography of a habitat generalist, the white-footed mouse, in a heterogeneous environment. Ecology 68: 1785-1796.

Allaire, P. N. 1979. The avifauna of reclaimed surface mined lands: its composition and role in land use planning. Ph.D. Dissertation, University of Louisville, Louisville, Kentucky.

Allaire, P. N. 1980. Bird species on mined lands: assessment and utilization in Eastern Kentucky. Institute for Mining and Minerals Research, Kentucky Center for Energy Research Laboratory, University of Kentucky, Lexington, Kentucky. 53 pp.

Amrani, C.R. 1987. Habitat use and metal accumulation by selected small mammals occurring in surface mine cattail marshes. M.S. Thesis, West Virginia University, Morgantown, West Virginia.

Balcerzak, M. J. 2001. Raptor Abundance and Diversity and Red-shouldered Hawk (Buteo lineatus) Habitat Characteristics on Reclaimed Mountaintop Mines in Southern West Virginia. M.S. Thesis, West Virginia University, Morgantown, West Virginia.

Balcom, B. J., and R. H. Yahner. 1996. Microhabitat and landscape characteristics associated with the threatened Allegheny woodrat. Conservation Biology 10:515-525.

Batzli, G.O. 1977. Population dynamics of the white-footed mouse in floodplain and upland forests. American Midland Naturalist 97: 18-32.

Bayne, E. M. and K. A. Hobson. 1998. The effects of fragmentation by forestry and agriculture on the abundance of small mammals in the southern boreal mixedwood forest. Canadian Journal of Zoology 76: 62-69. 
Beans, B. E. 1992. Without a trace: the puzzling demise of the Allegheny woodrat. Audubon 94: $32-34$.

Beauvais, G. P. and S. W. Buskirk. 1999. Modifying estimates of sampling effort to account for sprung traps. Wildlife Society Bulletin 27(1): 39-43.

Beers, T. W., P. E. Dress, and L. C. Wensel. 1966. Aspect transformation in site productivity research. Journal of Forestry 64: 691-692.

Bellows, A. S. and J. C. Mitchell. 2000. Small mammal communities in riparian and upland habitats on the upper coastal plain of Virginia. Virginia Journal of Science 51: 171-186.

Blackburn, L. D. and R. D. Andrews. 1992. Higher efficiency of pitfall traps in capturing three shrew species for analysis of diet and habitat. Transactions of the Illinois State Academy of Science 85(3-4): 173-181.

Buckner, C. A. and D. J. Shure. 1985. The response of Peromyscus to forest opening size in the southern Appalachian Mountains. Journal of Mammalogy 66:299-307.

Burt, W. H. and F. S. Barkolow. 1942. A comparative study of the bacula of woodrats (Subfamily Neotominae). Journal of Mammalogy 23: 287-297.

Bury, R. B. and P. S. Corn. 1987. Evaluation of pitfall trapping in northwestern forests: trap arrays with drift fences. Journal of Wildlife Management 51:112-119.

Caldwell, R.S. and H. Bryan. 1982. Notes on distribution and habitats of Sorex and Microsorex (Insectivora: Soricidae) in Kentucky. Brimleyana 8:91-100.

Campbell, H. W. and S. P. Christman. 1982. Field techniques for herpetofaunal community analysis. Pages 193-200 in Scott, N. J., Ed. Herpetological communities. U. S. Fish and Wildlife Service Resource Report Number 13. 
Castleberry, N. L. 2000a. Food habits of the Allegheny woodrat. M.S. Thesis, West Virginia University, Morgantown, West Virginia.

Castleberry, S. B. 2000b. Conservation and management of the Allegheny woodrat in the Central Appalachians. Ph.D. Diss. West Virginia University, Morgantown, West Virginia 166 pp.

Castleberry, S. B., P. B. Wood, W. M. Ford, N. L. Castleberry, and M. T. Mengak. 2002.

Summer microhabitat selection by foraging Allegheny woodrats (Neotoma magister) in a managed forest. American Midland Naturalist 147: 93-101.

Castleberry, S. B.,W. M. Ford, P. B. Wood, N. L. Castleberry, and M. T. Mengak. 2001. Movements of Allegheny woodrats in relation to timber harvesting. Journal of Wildlife Management 65: 148-156.

Cody, R. P. and J. K. Smith. 1997. Applied Statistics and the SAS programming language. Simon and Schuster, $445 \mathrm{pp}$.

Connor, P.F. 1959. The bog lemming Synaptomys cooperi in southern New Jersey. Publication of the Museum of Michigan State University Biological Service 1:161-248.

Corn, S. P. 1994. Straight line drift fences and pitfall traps. Pages 109-117 in Heyer, W. K., M. A. Donnely, R. W. McDarmid, L. C. Hayek, and M. S. Foster, editors. Measuring and monitoring biological diversity: standard methods for amphibians. Smithsonian Institute Press, Washington D. C.

De Capita, M.E. and T.A. Bookout. 1975. Small mammal populations, vegetational cover and hunting use of an Ohio strip-mine area. Ohio Journal of Science 75:305-313.

Doyle, A. T. 1990. Use of riparian an upland habitats by small mammals. Journal of Mammalogy 71(1): 14-23. 
Enge, K. M. 1997. Use of silt fencing and funnel traps for drift fences. Herpetological Review 28:30-31.

Fedorko, N. and M. Blake. 1998. A geologic overview of mountaintop removal mining in West Virginia. Executive Summary of a Report to the Committee on Post-mining Land Use and Economic Aspects of Mountaintop Removal Mining. West Virginia Geologic and Economic Survey (WVGES). 17 pp.

Forren, J. D. 1981. Artificial perch use by raptors on reclaimed surface mines in West Virginia. M. S. Thesis, West Virginia University, Morgantown, West Virginia.

Fowle, C.D. and R.Y. Edwards. 1955. An unusual abundance of short-tailed shrews, Blarina brevicauda. Journal of Mammology 36:36-41.

Gardner, B. M. and R. G. McLusky. 2000. Valley fills and the Clean Water Act: the strange confluence of the Clean Water Act and SMCRA in Bragg v. Robertson. Energy and Mineral Law Institute Ch. 8: 271-297.

Gentry, J.B., F.B. Golley, and J.T. McGinnis. 1966. Effect of weather on captures of small mammals. American Midland Naturalist 75:526-530.

George, S.B., J.R. Choate, and H.H. Genoways. 1986. Blarina brevicauda. Mammalian Species No. 261. American Society of Mammalogy.

Getz, L. L. 1961. Factors influencing the local distribution of shrews. American Midland Naturalist 65: 67-88.

Getz, L. L. 1984. Population dynamics of the short-tailed shrew, Blarina brevicauda. Special Publication of the Carnegie Museum of Natural History 18: 27-38.

Getz, L. L. 1989. A 14-year study of Blarina brevicauda populations in east-central Illinois. Journal of Mammalogy 70(1): 58-66. 
Goldman, E. A. 1910. Revision of the woodrats of the genus Neotoma. North American Fauna 31: 1-124.

Gomez, D. M. and R. G. Anthony. 1998. Small mammal abundance in riparian and upland areas of 5 seral stages in western Oregon. Northwest Science 72: 293-302.

Goodell, J. 2001. How coal got its glow back. New York Times Magazine. July 22.

Gotelli, N.J. 1998. A primer of ecology, 2nd edition. Sinauer and Associatess, Inc., Publishers. $236 \mathrm{pp}$.

Gottfried, B. M. 1977. Small mammal populations in woodlot islands. American Midland Naturalist 102: 105-112.

Greene, B. C. and W.B. Raney. 1979. Surface Mining in West Virginia: the state of the practice. Proceedings of the West Virginia Academy of Science 51: 186-210.

Hall, J. S. 1981. The mammals of North America. $2^{\text {nd }}$ Ed. John Wiley and Sons, New York.

Hall, J. S. 1985. Threatened eastern woodrat Neotoma floridana. Special Publication of the Carnegie Museum of Natural History 11:362-365.

Hansen, L.P. and Warnock, J.E. 1978. Response of two species of Peromyscus to vegetational succession on land strip-mined for coal. American Midland Naturalist 100: 416-423.

Hanski, I. 1996. Metapopulation ecology. In Population dynamics in ecological space and time, ed. O.E. Rhodes, R.K. Chesser, and M.H. Smith. University of Chicago Press.

Hayes, J. P. and M. E. Richmond. 1993. Clinal variation and morphology of woodrats (Neotoma) of the eastern United States. Journal of Mammalogy 74: 204-216.

Hayes, J. P. and R. G. Harrison. 1992. Variation in mitochondrial DNA and the biogeographic history of woodrats (Neotoma) of the eastern United States. Systematic Biology 41: 331344. 
Hicks, A. 1989. Whatever happened to the Allegheny woodrat? Pages 34-38 in The Conservationist (March-April), New York State Department of Environmental Conservation, Albany, New York.

Hicks, A. and E. McGowin. 1996. Baylisascaris procyonis: the probable cause of extirpation of the Allegheny woodrat in New York State. Page 4 in Mengak, M. T., Editor. Abstracts of the 1996 Allegheny Woodrat Recovery Group Meeting, Ferrum College, Ferrum, Virginia.

Hutchins, J. C. 1978. Surface coal mining and reclamation in Appalachia. Pp 53-68 in Surface mining and fish/wildlife needs in the eastern United States; proceedings of a symposium (ed. Samuel, D. E.., J. R. Stauffer, C. H. Hocutt, and W. T. Mason, Jr.).

James, F. C. and H. H. Shugart. 1970. A quantitative method of habitat description. Audubon Field Notes 24:727-736.

Janofsky, M. 1998. As hills fill hollows, some West Virginia residents are fighting king coal. The New York Times, May 7, 1998. 147: A24.

Johnson, S. A. and R. F. Madej. 1993. A 1991-1992 survey of recent occurrences of the eastern woodrat in Indiana. Indiana Department of Natural Resources Publication, March 1, 1993. $12 \mathrm{pp}$.

Jones, C., W. J. McShea, M. J. Conroy, T. H. Kunz. 1996. Chapter 8: Capturing Mammals. p. 120. In Wilson, D.E. et al. (editors), Measuring and Monitoring Biological Diversity: Standard Methods for Mammals. Smithsonian Institution Press, Washington, DC. 409 pp.

Kaufman, D. W. and G. A. Kaufman. 1982. Effect of moonlight on activity and microhabitat use by Ord's kangaroo rat (Dipodomys ordii). Journal of Mammalogy 63: 309-312. 
Kaufman, D. W. and G. A. Kaufman. 1990. House mice (Mus musculus) in natural and disturbed habitats in Kansas. Journal of Mammalogy 71: 428-432.

Kirkland, G. L., Jr. 1976. Small mammals of a mine waste situation in the central Adirondacks, New York: A case of opportunism by Peromyscus maniculatus. American Midland Naturalist 95:103-110.

Kirkland, G. L., Jr. 1977. Responses of small mammals to the clearcutting of northern Appalachian forests. Journal of Mammalogy 58: 600-609.

Kirkland, G. L., Jr. 1994. Proposed standard protocol for sampling small mammal communities. Special Publication of the Carnegie Museum of Natural History 1994: 0(18): 277-283.

Kirkland, G. L., Jr. and P. M. Krim. 1990. Survey of the statuses of the mammals of Pennsylvania. Journal of the Pennsylvania Academy of Science 64: 33-45.

Krupa, J. J. and K. E. Haskins. 1996. Invasion of the meadow vole (Microtus pennsylvanicus) in southeastern Kentucky and its possible impact on the southern bog lemming (Synaptomys cooperi). American Midland Naturalist 135:14-22.

Lidicker, W. Z., Jr. 1975. The role of dispersal in the demography of small mammals. Pp. 103128 in Small mammals: their productivity and population dynamics (F. B. Golley, K. Petrusewicz, and L. Ryszkowski, eds.). Cambridge University Press, New York. 451 ppp.

Lindeborg, R.G. 1941. Fluctuations in the abundance of small mammals in east-central Illinois, 1936-1939. Ecology 22: 96-99.

Linzey, A. V. 1983. Synaptomys cooperi. Mamm. Species. No. 210. Am. Soc. Mamm. 5 pp. Linzey, A. V. 1989. Response of white-footed mouse (Peromyscus leucopus) to the transition between disturbed and undisturbed habitats. Canadian Journal of Zoology 67: 505-512.

Loeb, P. 1997. Special Report: Shear Madness. U.S. News and World Report, October 13, 1997. 
MacArthur, R.H. and E.O. Wilson. 1967. The theory of island biogeography. Princeton: Princeton University Press, Princeton, N. J.

Mahan, C. G. and R. H. Yahner. 1999. Effects of forest fragmentation on behavior patterns in the eastern chipmunk (Tamias striatus). Canadian Journal of Zoology 77(12): 1991-1997.

Martin, C. M., H. S. Zim, and A. L. Nelson. 1951. American wildlife and plants: a guide to wildlife food habits. Dover Publications, Inc. New York, New York. 500 pp.

Martin, T. E., C. Paine, C. J. Conway, W. M. Hochachka, P. Allen, and W. Jenkins. 1997. Breeding biology research and monitoring database (BBIRD) field protocol. Missoula, MT: University of Montana Cooperative Wildlife Research Unit, 64 pp.

McConnell, D. L. and D. E. Samuel. 1985. Small mammal and avian populations utilizing cattail marshes on reclaimed surface mines in West Virginia. Pages 329-336 in Brooks, R. P., D. E. Samuel, and J. B. Hill, Eds. Wetlands and water management on mine lands. Conference Proceedings, The Pennsylvania State University, State College, Pa.

McCracken, K. E., J. W. Witham, and M. L. Hunter, Jr. 1999. Relationships between seed fall of three tree species and Peromyscus leucopus and Clethrionomys gapperi during 10 years in an oak-pine forest. Journal of Mammalogy 80:1288-1296.

McCravy, K. W. and R. K. Rose. 1992. An analysis of external features as predictors of reproductive status in small mammals. Journal of Mammalogy 73: 151-159.

McGowan, K. J. and T. A. Bookout. 1986. Small mammal populations on Ohio strip-mined lands reclaimed with herbaceous vegetation under old and new reclamation laws. Ohio Journal of Science 86(1): 29-32. 
Mengak, M. T. 1996. Status and distribution of woodrat metapopulations in Virginia. Pages 2-3 in Mengak, M. T., Editor. Abstracts of the 1996 Allegheny Woodrat Recovery Group Meeting, Ferrum College, Ferrum, Virginia.

Mindell, D. P. 1978. Habitat use by Red-tailed hawks in surface mined areas. M. S. Thesis, West Virginia University, Morgantown, West Virginia.

Moore, J.C. 1949. Notes on the shrew, Sorex cinereus, in the southern Applachians. Ecology 30: 234-237.

Mumford, R. E. and W. C. Bramble. 1973. Small mammals on surface-mined land in southwestern Indiana. In Hutnik, R. J. and G. Davis, Editors. Ecology and reclamation of devastated land, Volume 1. Gordon and Breach, Science Publishers Inc.

Myers, R. T. 1997. Microhabitat and ecology of the Allegheny woodrat in north-central West Virginia. M.S. Thesis, West Virginia University, Morgantown, West Virginia 83 pp.

Nelson, L. and F. W. Clark. 1972. Correction for sprung traps in catch/effort calculations of trapping results. Journal of Mammalogy 54: 295-298.

Newcombe, C. L. 1930. An ecological study of the Allegheny cliff rat (Neotoma pennsylvanica Stone). Journal of Mammalogy 11: 204-211.

Nieman, T. J. and Z. R. Merkin. 1995. Wildlife management, surface mining, and regional planning. Growth and Change 26: 405-424.

Nupp, T. E. and R. K. Swihart. 1996. Effect of forest patch area on population attributes of white-footed mice (Peromyscus leucopus) in fragmented landscapes. Canadian Journal of Zoology 74: 467-472.

Nupp, T. E. and R. K. Swihart. 1998. Effects of forest fragmentation on population attributes of white-footed mice and eastern chipmunks. Journal of Mammalogy 79: 1234-1243. 
Nur, N., S. L. Jones, and G. R. Geupel. 1999. Statistical guide to data analysis of avian monitoring progams. U.S. Fish and Wildlife Service Publication, BTP-R6001-1999. Washington, D. C.

Office of Surface Mining Reclamation and Enforcement (OSM), U.S. Dept. of Interior. 2001. Annual evaluation summary report for the regulatory and abandoned mine reclamation programs administered by the state of West Virginia for evaluation year 2000. OSM Charleston Field Office, Charleston, West Virginia. 52 pp.

Office of Surface Mining Reclamation and Enforcement (OSM), U.S. Dept. of Interior. 1999. An evaluation of approximate original contour and postmining land use in West Virginia: Final Report. OSM Charleston Field Office, Charleston, West Virginia. 18 pp.

Pack, J. C. 1998. Mast Survey and West Virginia hunting outlook. West Virginia Division of Natural Resources Publication, Wildlife Resources Section.

Pack, J. C. 1999. Mast Survey and West Virginia hunting outlook. West Virginia Division of Natural Resources Publication, Wildlife Resources Section.

Pais, R. C., S. A. Bonney, and W. C. McComb. 1988. Herpetofaunal species richness and habitat associations in an eastern Kentucky forest. Proceedings of the Annual Conference of the Southeastern Association of Fish and Wildlife Agencies 42:448-455.

Pearson, P. G. 1952. Observations concerning the life history and ecology of the woodrat, Neotoma floridana floridana (Ord). Journal of Mammalogy 33: 459-463.

Pennsylvania Game Commission. 1996. Allegheny woodrat survey code manual. Bureau of Wildlife Management, Harrisburg, Pennsylvania. 11 pp.

Planz, J. V., E. G. Zimmerman, T. A. Spradling, and D. R. Akins. 1996. Molecular phylogeny of Neotoma floridana species group. Journal of Mammalogy 77:519-535. 
Poole, E. L. 1940. A life history sketch of the Allegheny woodrat. Journal of Mammalogy 21: 249-270.

Pulliam, H.R. 1988. Sources, sinks, and population regulation. American Naturalist 132: 652661.

Pulliam, H.R. 1996. Sources and sinks: empirical evidence and population consequences. In Population dynamics in ecological space and time, ed. O.E. Rhodes, R.K. Chesser, and M.H. Smith. University of Chicago Press.

Pyare, S., J.A. Kent, D.I. Noxon, and M.T. Murphy. 1993. Acorn preference and habitat use in eastern chipmunks. American Midland Naturalist 130:173-183.

Rhoads, S. N. 1894. A contribution to the life history of the Allegheny cave rat, Neotoma magister baird. Proceedings of the Academy of Natural Sciences of Philadelphia, pp. 213-221.

Rhodes, D.H. and M.E. Richmond. 1985. Influence of soil texture and temperature on nest-site selection and burrowing by the pine vole, Microtus pinetorum. American Midland Naturalist 113: 102-108.

Rich, S. M., C. W. Kilpatrick, J. L. Shippee, and K. L. Crowell. 1996. Morphological differences and identification of Peromyscus leucopus and Peromyscus maniculatus in northeastern North America. Journal of Mammalogy 77: 985-991.

Robel, R. J., J. N. Briggs, A. D. Dayton, and L. C. Hulbert. 1970. Relationships between visual obstruction measurements and weight of grassland vegetation. Journal of Range Management 23:295-297. 
Robins J. D. and J. C. Hutchins. 1979. Environmental assessment of surface mining methods: head-of-hollow fill and mountaintop removal: interim report. Skelly and Loy, Harrisburg, Penn. 223 pp.

Robins J. D. and J. C. Hutchins. 1984. Environmental assessment of surface mining methods: head-of hollow fill and mountaintop removal, Volume 1. Skelly and Loy, Harrisburg, Penn. 210 pp.

Root, B.G. 1990. Peromyscus leucopus response to clearcutting in a Missouri oak-hickory forest. Transactions of the Missouri Academy of Science 24: 43-48.

Rosenblatt, D.L., E.J. Heske, S.L. Nelson, D.M. Barber, M.A. Miller, and B. MacAllister. 1999. Forest fragments in east-central Illinois: Islands or habitat patches for mammals? American Midland Naturalist 141:115-123.

Schwartz, A. and E. P. Odum. 1957. The woodrats of the eastern United States. Journal of Mammalogy 38: 197-206.

Sly, G.R. 1976. Small mammal succession on strip-mined land in Vigo County, Indiana. American Midland Naturalist 95:257-267.

Stamp, N. E. and R. D. Ohmart. 1979. Rodents of the desert shrub and riparian woodland habitats in the Sonoran Desert. The Southwestern Naturalist. 24: 279-289.

Stihler, C. and J. Wallace. 1996. Woodrat studies in West Virginia. Page 2 in Mengak, M. T., Editor. Abstracts of the 1996 Allegheny Woodrat Recovery Group Meeting, Ferrum College, Ferrum, Virginia.

Szaro, R. C., L. H. Simons, and S. C. Belfit. 1988. Comparative effectiveness of pitfalls and livetraps in measuring small mammal community structure. Paper presented at symposium, 
Management of Amphibians, Reptiles, and Small Mammals in North America. Flagstaff, AZ. July 19-21.

Terpening, V.A., B.N. Jacobsen, J.R. Nawrot, M.J. Sweet, M.T. Dooley, A.L. Dooley, D.L. Damrau, and W.D. Klimstra. 1975. Environmental inventory and assessment of the proposed New Delta Mine Expansion in southeastern Illinois. Cooperative Wildlife Research Laboratory, Southern Illinois University, Carbondale, Ill.

Travers, S. E., D. W. Kaufman, and G. A. Kaufman. 1988. Differential use of experimental habitat patches by foraging Peromyscus maniculatus on dark and bright nights. Journal of Mammalogy 69: 869-872.

U. S. Environmental Protection Agency (EPA). 1998. Mid-Atlantic States State of the Environment: The Challenge Ahead. EPA Region III pub. 903-R-99-005. 68 pp.

Urbanek, R. P. and Klimstra, W. D. 1986. Vertebrates and vegetation on a surface-mined area in southern Illinois. Transactions of the Illinois State Academy of Science 79: 175-188.

van Hensbergen, H. J. and S. C. Martin. 1993. Climatic factors affecting trapping success of some South African small mammals. South African Journal of Wildlife Research 23: 8794.

Van Horne, B. 1982. Niches of adult and juvenile deer mice (Peromyscus maniculatus) in seral stages of coniferous forest. Ecology 63: 992-1003.

Van Horne, B. 1983. Density as a misleading indicator of habitat quality. Journal Wildlife Management 47(4): 893-901.

Verts, B. J. 1957. The population and distribution of two species of Peromyscus on some Illinois strip-mined land. Journal of Mammalogy 38:53-59. 
Verts, B. J. 1959. Notes on the ecology of mammals of a strip-mined area in southern Illinois. Transactions of the Illinois State Academy of Science 52: 134-139.

Vickery, W. L. and D. Rivest. 1992. The influence of weather on habitat use by small mammals. Ecography 15: 205-211.

Vickery, W. L. and J. R. Bider. 1981. The influence of weather on rodent activity. Journal of Mammalogy 62: 140-145.

Vogt, R. C. and R. L. Hine. 1982. Evaluation of techniques for assessment of amphibian and reptile populations in Wisconson. Pages 201-217 in Scott, N. J., Ed. Herpetological communities. U. S. Fish and Wildlife Service Resource Report No. 13.

Voight, J. R. and D. C. Glenn-Lewin. 1979. Strip mining, Peromyscus and other small mammals in southern Iowa. Proceedings of the Iowa Academy of Science 86: 133-136.

Vollers, M. 1999. Razing Appalachia: miners fight to keep their towns on the map. Utne Reader. Nov.-Dec. 1999: 68-73.

Wagle, E. R. and G. A. Feldhammer. 1997. Feeding habits of the eastern woodrat (Neotoma floridana) in southern Illinois. Transactions of the Illinois State Academy of Sciences 90: $171-177$.

Ward, K. Jr. 1998. Mining the mountains; a series on mountaintop removal mining. The Charleston Gazette, Charleston, West Virginia.

Ward, K. Jr. 2001. Mining the mountains; a series on mountaintop removal mining. The Charleston Gazette, Charleston, West Virginia.

Ward, K. Jr. 2002. Mining the mountains; a series on mountaintop removal mining. The Charleston Gazette, Charleston, West Virginia. 
Warrick, J. 1998. Mountaintop removal shakes coal state; cost of prosperity hits close to home. The Washington Post, August 31, 1998 pA1 col 4 (60 col in).

West Virginia Nongame Wildlife \& Natural Heritage Program. 2000. Rare, threatened \& endangered vertebrate species in West Virginia: A listing of vertebrates believed rare in West Virginia. Wildlife Resources Section, West Virginia DNR.

Wetzel, R. M. 1958. Mammalian succession on midwestern floodplains. Ecology. 39: 262-271. Wharton, C.H. and J.J. White. 1967. The red-backed vole, Clethrionomys gapperi, in north Georgia. Journal of Mammalogy 48:670-672.

Whitaker, J. O. and W. E. Wrigley. 1972. Napaeozapus insignis. Mammalian species No. 14. American Society of Mammalogy.

Whitaker, J. O. and W. J. Hamilton. 1998. Mammals of the Eastern United States $3^{\text {rd }}$ Ed. Comstock Publishing Associates, Ithaca, N. Y.

Wiley, R. W. 1980. Neotoma floridana. Mammalian Species. No. 139. American Society of Mammalogy $7 \mathrm{pp}$.

Williams, T. 2001. Mountain madness. Audubon. May-June.

Wolff, J. O. 1985. Comparative population ecology of Peromyscus leucopus and Peromyscus maniculatus. Canadian Journal of Zoology 63: 1548-1555.

Wolff, J. O. 1996. Population fluctuation of mast-eating rodents are correlated with production of acorns. Journal of Mammalogy 77:850-856.

Wood, P. B. 2001. Characteristics of Allegheny woodrat (Neotoma magister) habitat in the New River Gorge National River, West Virginia. Final Project Report, West Virginia Cooperative Fish and Wildlife Research Unit, BRD/USGS and West Virginia University, PO Box 6125, Morgantown, West Virginia, 45 pp. 
Wood, P. B., J. W. Edwards, C. A. Weakland, H. D. Chamblin, and M. J. Balcerzak. 2000. Mountaintop removal/valley fill environmental impact statement technical study. EPA Publication.

Wray, T. II, K. A. Strait, and R. C. Whitmore. 1982. Reproductive success of grassland sparrows on a reclaimed surface mine in West Virginia. Auk 99:157-163.

Yahner, R. H. 1986. Spatial distribution of white-footed mice (Peromyscus leucopus) in fragmented forest stands. Proceedings of the Pennsylvania Academy of Science 60(2): $165-166$.

Yahner, R. H. 1992. Dynamics of a small mammal community in a fragmented forest. American Midland Naturalist 127: 381-391.

Yeager, L. E. 1942. Coal-stripped land as a mammal habitat, with special reference to fur animals. American Midland Naturalist 27: 613-635.

Yearsley, E. F. and D.E. Samuel. 1980. Use of reclaimed surface mines by foxes in West Virginia. Journal of Wildlife Management 44: 729-734.

Zar, J. H. 1999. Biostatistical Analysis (Fourth Edition). Prentice Hall Publishing. 663 pp. 
APPENDIX A - STATISTICAL MODELS USED IN ANALYSIS OF VARIANCE OF SMALL MAMMAL RICHNESS, ABUNDANCE AND HABITAT VARIABLES 
Table A. 1. Analysis of variance model used to test the effects of treatment on species richness, total small mammal abundance, species-specific abundance, and reproductive condition of Peromyscus spp. individuals for 1999 Sherman live-trapping data.

Source of Variation $\quad d f$ Description of Variable

Treatment 2Treatment sampled (grasslands, fragmented forest, or intact forest)

Block 3 Group of concurrently trapped transects representing each treatment

Block x Treatment 6Interaction between treatment and block

Table A. 2. Analysis of variance model used to test the effects of treatment on species richness, total small mammal abundance, species-specific abundance, and reproductive condition of Peromyscus spp. individuals for 2000 Sherman live-trapping data.

\begin{tabular}{ll}
\hline Source of Variation & $d f$ Description of Variable \\
\hline Treatment & 3 Treatment sampled (grasslands, shrub/pole, fragmented forest, or intact forest) \\
Block & 4Group of concurrently trapped transects representing all treatments \\
Block x Treatment & 10Interaction between treatment and block \\
\hline
\end{tabular}

Table A. 3. Analysis of variance model used to test the effects of year on species richness, total small mammal abundance, species-specific abundance, and reproductive condition of Peromyscus spp. individuals (each treatment analyzed separately) for Sherman live-trapping data.

\begin{tabular}{ll}
\hline Source of Variation & $d f$ Description of Variable \\
\hline Year & 1Year of sampling \\
Block & 4Group of concurrently trapped transects representing all treatments \\
Year x Block & 3Interaction between year and block \\
\hline
\end{tabular}

Table A. 4. Analysis of variance model used to test the effects of treatment on species richness, total small mammal abundance, and species-specific abundance for drift fence array data.

Source of Variation $\quad d f$ Description of Variable

Treatment 3 Treatment sampled (grasslands, shrub/pole, fragmented forest, or intact forest)

Trapping session $\quad$ 125-12 day session conducted approximately each month from March-September 2000 and 2001

Treatment $\mathrm{x}$ Session 36 Interaction between treatment and trapping session

Table A. 5. Analysis of variance model used to test the effects of treatment on habitat variables for Sherman and drift fence array data.

\begin{tabular}{ll}
\hline Source of Variation & $d f$ Description of Variable \\
\hline Treatment & 3Treatment sampled (grasslands, shrub/pole, fragmented forest, or intact forest) \\
\hline
\end{tabular}


APPENDIX B - MAPS AND AERIAL PHOTOGRAPHS OF STUDY SITES 


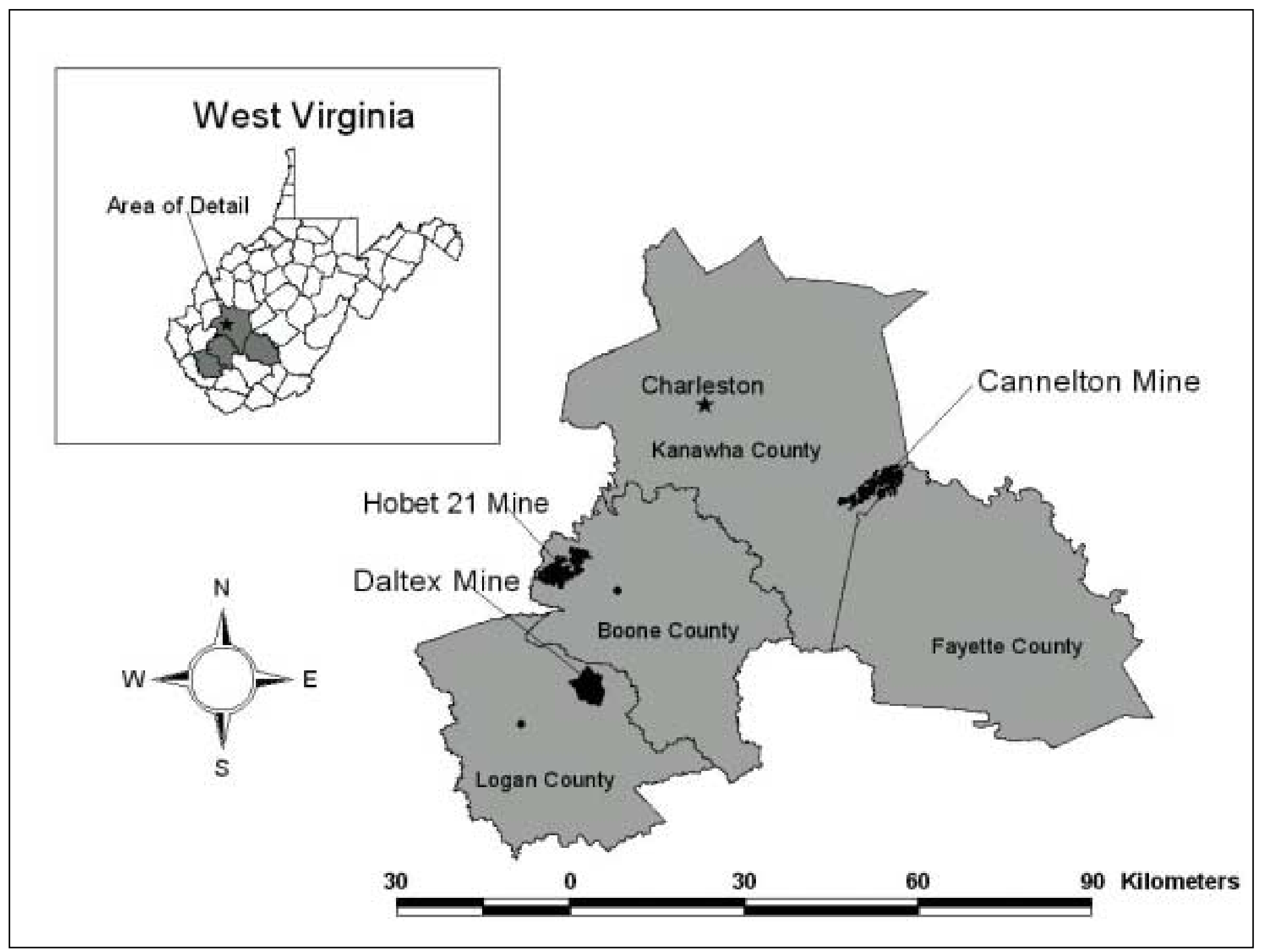

Figure B. 1. Location of study sites at Hobet 21, Daltex, and Cannelton Mines in southern West Virginia. 


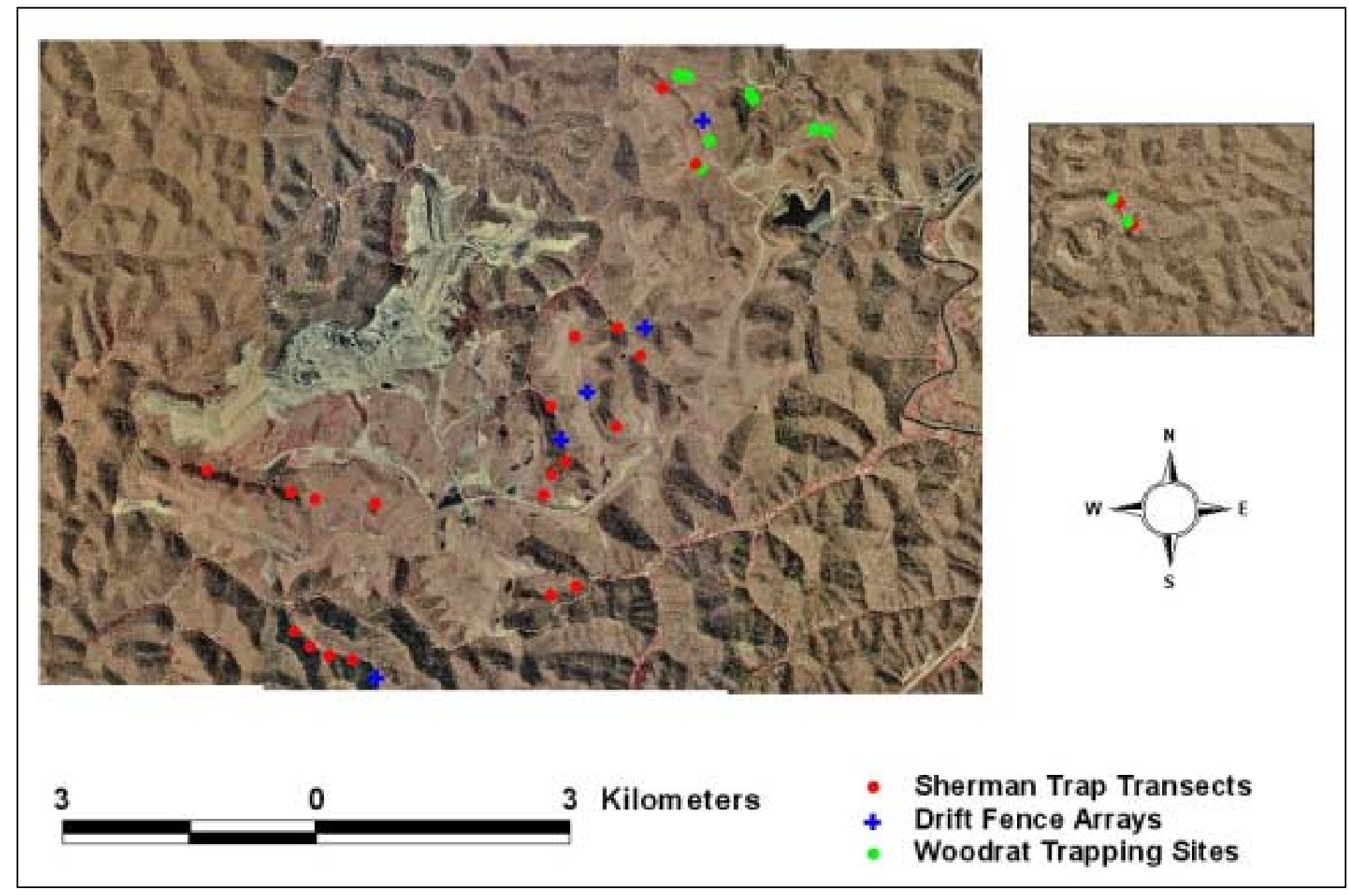

Figure B. 2. Aerial photograph of Hobet 21 Mine in Boone County, West Virginia showing locations of Sherman trapping transects, woodrat trapping sites, and drift fence arrays. Inset shows Hill Fork area located about $8 \mathrm{~km}$ northeast of main complex. 


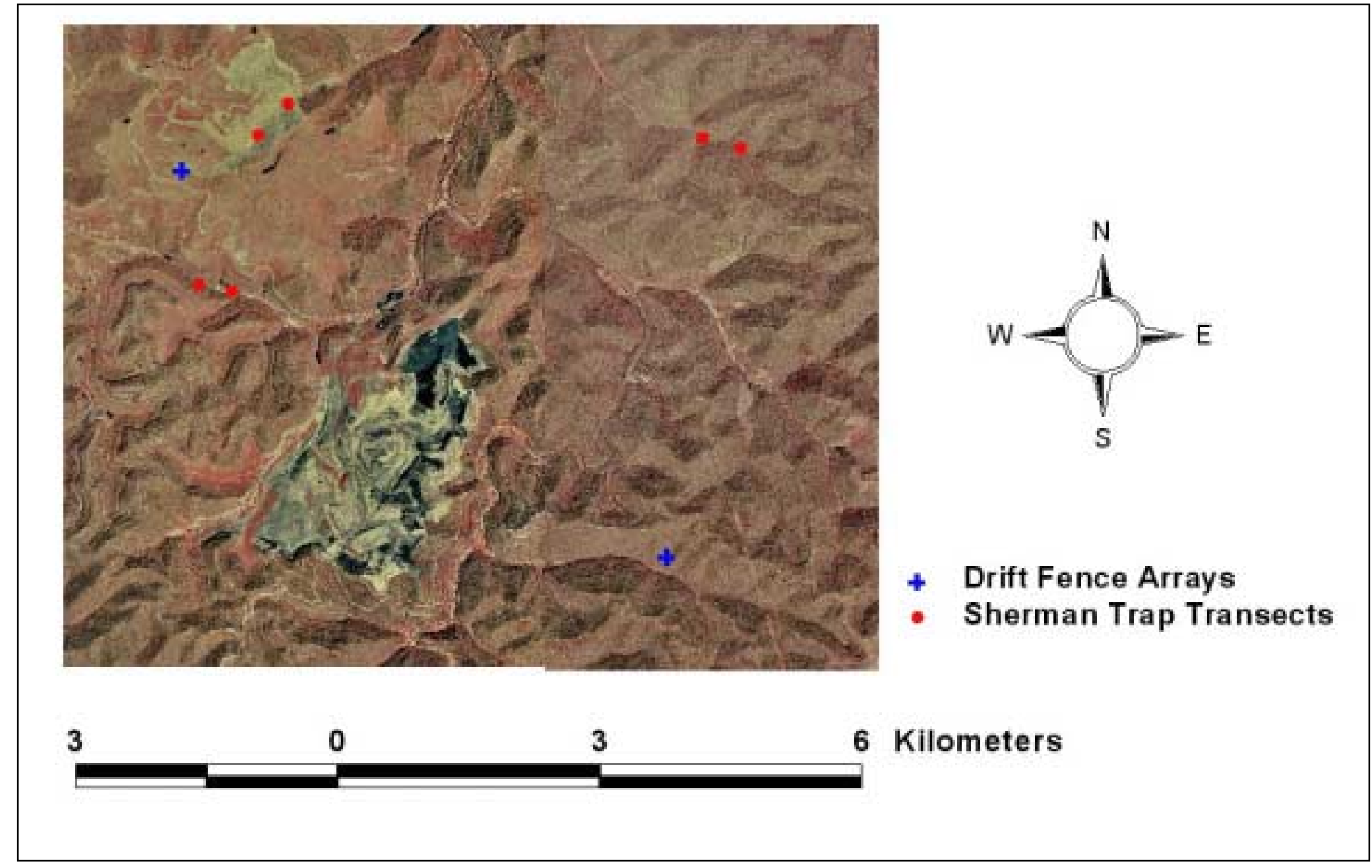

Figure B. 3. Aerial photograph of Daltex Mine in Logan County, West Virginia showing locations of Sherman trapping transects and drift fence arrays. 


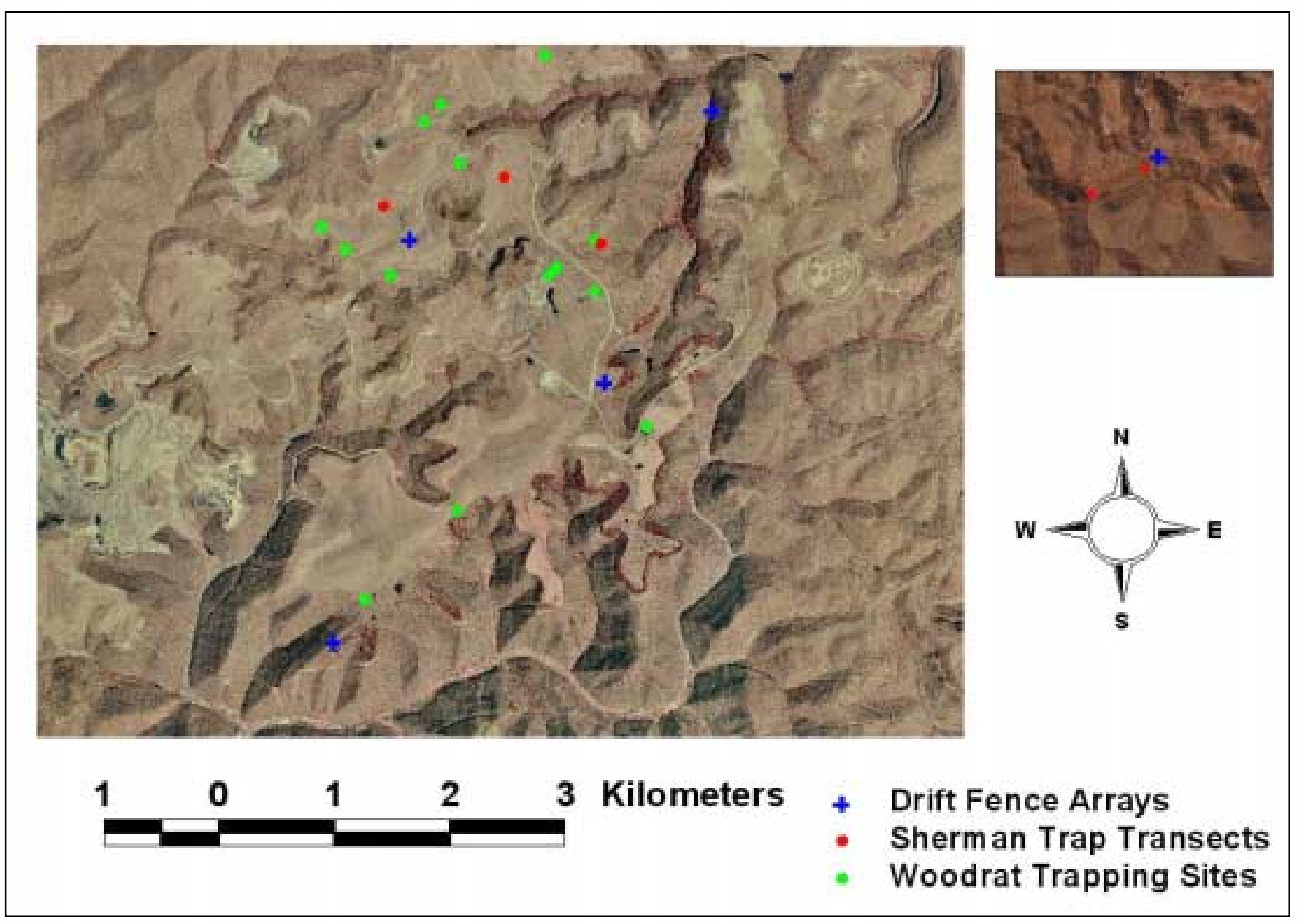

Figure B. 4. Aerial photograph of Cannelton Mine on the border of Fayette and Kanawha Counties, West Virginia showing locations of Sherman trapping transects and drift fence arrays. Inset shows Ash Fork intact forest site located about 14 km northeast of the mine. 